\title{
Public accountability in public health in China
}

Citation for published version (APA):

Yang, R. (2020). Public accountability in public health in China: managing food and vaccine incidents.

[Doctoral Thesis, Maastricht University]. Maastricht University. https://doi.org/10.26481/dis.20201005ry

Document status and date:

Published: 01/01/2020

DOI:

10.26481/dis.20201005ry

Document Version:

Publisher's PDF, also known as Version of record

\section{Please check the document version of this publication:}

- A submitted manuscript is the version of the article upon submission and before peer-review. There can be important differences between the submitted version and the official published version of record.

People interested in the research are advised to contact the author for the final version of the publication, or visit the DOI to the publisher's website.

- The final author version and the galley proof are versions of the publication after peer review.

- The final published version features the final layout of the paper including the volume, issue and page numbers.

Link to publication

\footnotetext{
General rights rights.

- You may freely distribute the URL identifying the publication in the public portal. please follow below link for the End User Agreement:

www.umlib.nl/taverne-license

Take down policy

If you believe that this document breaches copyright please contact us at:

repository@maastrichtuniversity.nl

providing details and we will investigate your claim.
}

Copyright and moral rights for the publications made accessible in the public portal are retained by the authors and/or other copyright owners and it is a condition of accessing publications that users recognise and abide by the legal requirements associated with these

- Users may download and print one copy of any publication from the public portal for the purpose of private study or research.

- You may not further distribute the material or use it for any profit-making activity or commercial gain

If the publication is distributed under the terms of Article $25 \mathrm{fa}$ of the Dutch Copyright Act, indicated by the "Taverne" license above, 
Public Accountability in Public Health in China: Managing Food and Vaccine Incidents

Ronghui Yang 



\title{
Public Accountability in Public Health in China: Managing Food and Vaccine Incidents
}

\author{
DISSERTATION
}

To obtain the degree of Doctor at the Maastricht University, on the authority of the Rector Magnificus Prof. dr. Rianne M. Letschert in accordance with the decision of the Board of Deans, to be defended in public on Monday, 5 October 2020 at 16:00 hours

By

Ronghui Yang 


\section{Supervisors}

Prof. Dr. K. Horstman, Maastricht University

Dr. B. Penders, Maastricht University

\section{Assessment Committee}

Prof. dr. G. de Wert (Chair)

Prof. dr. C. Hoebe

Dr. T. Krafft

Prof. dr. R. A. Bal, Erasmus University Rotterdam

Dr. J. Candel, Wageningen University 


\section{CONTENTS}

Chapter 1. Introduction. Constructing the governance of food and drug safety as a public issue in China $\mid \mathbf{1}$

Chapter 2. Constructing the accountability of food safety as a public problem in China: A document analysis of Chinese scholarship, 2008-2018 | 23

Chapter 3. Stakeholder perspectives on infant formula safety governance in China: A decade after the melamine crisis $\mid \mathbf{5 3}$

Chapter 4. Addressing vaccine hesitancy in China: A scoping review of Chinese scholarship | 71

Chapter 5. Vaccine hesitancy in China: A qualitative study of expert and lay perspectives | 95

Chapter 6. Conclusion. Public accountability of food and vaccine safety in China: How institutional efficiency, social responsiveness and democracy meet | $\mathbf{1 1 7}$

Valorisation of research insights | 135

Summary | 143

Acknowledgements |147

Curriculum vitae | 149

Scientific output | 151 



\section{Chapter 1}

Introduction: Constructing the governance of food and drug safety as a public issue in China 


\section{Introduction}

Food and drug safety is crucial to human welfare and wellbeing. Therefore, securing food and drug safety and protecting humans from risks of food poisoning and diseases is a major public health task. In 2005 the World Health Organization (WHO) issued the International Health Regulations, which suggest that nation states should include food and drug safety in national policies and plans and establish regulatory infrastructures to cope with public health crises effectively (World Health Organisation, 2008).

To address the threat of food contamination to international health security, this guideline regulates measures to foster WHO global partnerships and global alert and response systems, strengthens national surveillance, control and response systems and improves the capacity to manage risks in terms of food and drug safety (World Health Organisation, 2008, p. 19).

Ten years later, the burdens of foodborne diseases and illicit drugs were still high and fuelled global public health concerns (WHO, 2015). According to data released by the WHO in 2015, almost 1 in 10 people fall ill every year from eating contaminated food and 420,000 die as a result. Reported by the European Monitoring Centre for Drugs and Drug Addiction (2019), over 8,200 deaths in the EU involved one or more illicit drugs in 2017. This estimate exceeds 9,400 deaths when Norway and Turkey are included. The threat of foodborne illness and illicit drug-induced death has led to a call to implement strict food and drug regulations.

In China, a country with a population of 1,439 million inhabitants (almost $20 \%$ of the world population), food and drug safety regulation is considered a major public health issue as well. In the last few decades China has developed into a middle-income country, and currently it is even considered an upper middle-income country, which has come to play a major role in the global economy (Song, 2015b). This development implies that the economic, social and political relevance of food and health have increased. While food safety was dealt with by many different laws and regulations for a long time, in 1982, the Food Sanitation Law was implemented to ensure food hygiene and prevent food contamination ( $\mathrm{Li}, 2009 \mathrm{~b}$ ); in 2009, the $14^{\text {th }}$ Meeting of the Standing Committee of the $12^{\text {th }}$ National People's Congress of China enacted the Food Safety Law, to establish food safety standards and to construct a strict food safety regulation infrastructure 'from farm to table' throughout the country (Huang, 2009, p.149). To foster the effectiveness of the Food Safety Law the central state updated it in 2015 and in 2018 (Snyder, 2015; Kang, 2019). To construct a strict drug safety infrastructure, the Drug Administration Law of the People's Republic of China issued in 1985 was largely revised in 2015; all guidelines for drug producing, packaging, dosing and standards of drug safety regulation were updated (Song, 2015a). The engagement of China's top leaders in spurring policy implementation regarding food and drug safety underlined the importance of these 
laws in China. In 2016, Chinese President Xi Jinping urged the implementation of the 'strictest' measures to ensure food safety for the public. According to Yee and Liu (2019) and Lin (2019), Xi noted that the work to ensure food safety greatly impacts both people's livelihood and public confidence in the government and called on party and governmental authorities to perform their duties well and practise to ensure food safety and safeguard the public's interest.

Strengthening food safety is highly relevant to the people's livelihood project of states and to the immediate interests of thousands of households. Whether we can provide a satisfying solution on food safety to the people is an important test of our capacity of governance. We should implement the 'four strictest' requirements: emphasising the most stringent standards, the strictest supervision, the harshest punishment and adhering to the most serious accountability to ensure food safety (Xi quoted in China News Portal, 22 May 2019).

Meanwhile, according to Morris (2019), in 2019 Xi provided guidance for regulatory agencies to guard the bottom line of drug safety resolutely and pursue the development of high-quality drugs.

Reported by Morris (2019), Chinese President Xi Jinping told the authorities to 'improve the supervision and guard the bottom line of drug safety in order to safeguard public interest and social security'.

The continuous political attention on food and drug safety in China and a series of food and drug regulations can be understood in the context of incessant food and drug safety scandals in China over the last fifteen years, which have threatened people's life and destroyed public trust. These scandals include the incident of Sudan Red in duck's eggs in 2006, when duck farmers added the dye to the duck food to give the yolk a more intense red colour, which is dangerous for persons when consumed in great quantities ( $\mathrm{Li}, 2009 \mathrm{a}$ ); the 2008 melamine milk scandal involved infant formula adulterated with melamine to improve protein content (Pei et al., 2011); the illegal gutter oil incident in 2010, when many street vendors and restaurants illegally used recycled oil unfit for human consumption for the purposes of cooking food ( $\mathrm{Lu}$ and $\mathrm{Wu}, 2014)$ and the clenbuterol incident in 2011, when hundreds of people took ill after eating pork contaminated with clenbuterol (Zhang et al., 2012). Vaccine incidents include the hepatitis B vaccine incident in 2013, when the deaths of 17 children in China were reported after receiving hepatitis B inoculation (Chen et al., 2015; Yu et al., 2016); the Shandong vaccine incident in 2016, when it was reported that illegal vaccines affected hundreds of people in 24 provinces and cities (Cao et al., 2018) and the Changchun Changsheng vaccine scandal in 2018, when hundreds of thousands of children might have been injected with faulty vaccine produced by Changchun Changsheng (Cáceres, 2018). According to data released by the Chinese National Health Department, from 2008 to 2015 an average of 199.93 food poisoning incidents occurred each year, with an average annual number of poisoned persons of 7279.38 and an 
average annual death rate of 36.47 (Chen et al., 2017). Although there are no data showing the mortality from vaccination, according to the prediction of the National Health Commission in 2010, about 350 newborn babies die from hepatitis B vaccination each day in China (The National Health Commission, 2010).

These series of food and drug safety incidents in China have not only sparked Chinese citizens' distrust but also fuelled global concerns as Chinese manufacturers produce food and drugs for the global market. For instance, the melamine scandal in 2008 in China resulted not only in the loss of the domestic public trust in Chinese baby food but also in the rejection of Chinese infant formula by consumers in Southeast Asia, Hong Kong, Macao and other regions and in a decrease in exports of Chinese dairy products. Meanwhile, the Changchun Changsheng vaccine scandal in 2018 caused some Southeast Asian countries and India to stop the import of such vaccines from China, concerned about the safety of vaccines from China (Kedia, 2018).

Considering the importance of food and drug quality for Chinese and global public health, these public health incidents raise the question of how the governance of food and drug safety in China are constructed as public problems in China. Most studies of the governance of public health in general and food and drug safety specifically draw from theories of governance and public accountability that are developed in a Western democratic context (Wynne, 1992; May, 2007; Penders and Nelis, 2011; Horstman, 2015; Devaney, 2016). Inspired by this literature, I became interested in studying governance of food and drug safety in China, a country with an authoritarian political system (Lee and Zhang, 2013).

In the next section of this chapter, I will introduce the theoretical background of this study, namely scholarship in public accountability and in science and technology studies. Then I will explain the choice of both cases and the methodology. I also will illustrate the difficulties and dilemmas when doing qualitative research about food and drug safety in China. I will conclude this chapter by presenting the outline of the thesis.

\section{Theoretical background}

To study how governance and accountability of food and drug safety is constructed as a public problem in China, I drew from scholarly discussions about public accountability in a Western democratic context. These discussions consider accountability in terms of different actors in accountability processes, organisational mechanisms of accountability, specific social and political contexts the accountability operates in and relations of accountability to transparency, interaction and participation (Bovens et al., 2014). However, regulatory contexts for food and drug safety are not only defined by political actors and procedures but also by experts and knowledge infrastructure. Therefore, for this study I also drew from science and technology studies (STS), as far as it is 
developed in China. Both disciplinary backgrounds provide insights into public accountability as a public issue in China and help to explore the specific characteristics of public accountability in a non-democratic context.

\subsection{Public accountability studies}

In the Handbook of Public Accountability, which assembles a large body of scholarly literature about public accountability in Western contexts, Bovens et al. (2014) describe accountability as the answerability of an actor to others who have a legitimate standing to demand various information about the performance of tasks, outcomes and procedures by the actor and explanations and justifications of this performance (Bovens et al., 2014, p. 6). Accountability is furthermore introduced as a relational concept, linking actors to others for whom they perform tasks or who are affected by their performance. In the literature, this is often described in terms of a relationship between agents and principals. Finally, accountability is a consequential activity, entailing that these people who are being held accountable will be punished (Bovens et al., 2014, p. 6).

Public accountability scholars distinguish different meanings of 'public'. First, according to Dubnick (2014, p. 7), 'public' generally refers to openness or transparency to the citizens. Information provided about the performance of institutional actors, hearings and debates are generally open to the citizens, and assessments and judgements are shared with the citizens. Second, 'public' refers to the recipient of account-giving. Public accountability mainly focuses on the matters of public concern, such as the exercise of public powers or the conduct of public institutions (Bovens et al., 2014). Finally, 'public' refers to the perspective and standards of the accounting. Public accountability implies the rendering of an account for matters of public interest, that is an accounting performed with a view to the public interest or to public responsibilities (Dubnick, 2014, p. 7). In general, public accountability is accountability in and about the public domain, and most scholars assume this public domain to be developed and functioning in a democratic context, where diverse voices and perspectives play a role in discussing the standards of accountability.

In political science, two different usages of accountability can be observed. On the one hand, Warren (2014) argues that accountability is seen as a virtue, contributing to democratic governance. Accountability is seen as desirable quality of states, government organisations and officials. In democratic contexts a set of substantive standards for good governance is developed to assess whether officials or organisation comply with these standards, such as responsiveness, a sense of responsibility, or a willingness to act in a transparent, fair, compliant and equitable way (Warren, 2014, p. 8). On the other hand, Peters (2014) conceptualises accountability as a political or administrative mechanism to assess how institutional arrangements operate in terms of efficacy and with what effects. In this mode, the focus of accountability is not whether actors have behaved in a 
transparent or a responsive way but rather whether and how they are or can be held accountable ex post facto for incidents and misconduct. Informed by this notion of accountability, account-giving usually consists of three elements: the provision of explanation and justification, the possibility to interrogate the actor and to question the adequacy of explanation or the legitimacy of the conduct, and the passing of judgement on the conduct of the actor (Peters, 2014, p. 9).

Several dimensions revolve around essential questions to be asked about accountability: who is accountable to whom, for what, by which standards and why (Warren, 2014, p. 10)? Here bureaucratic, accountability and democratic accountabilities are distinguished-bureaucratic accountability refers to that public officials are shaped by bureaucratic hierarchies to be accountable to their superiors for political goals, professional accountability means that public officials try to be accountable to the stakeholders for professional norms and standards, and democratic accountability entails that various accountability mechanisms are concurrently present, and more actors are involved whose behaviour can be held accountable (Dubnick, 2014; Warren, 2014).

The field of public accountability studies has developed in Western democratic countries, and key ideas and concepts refer to scholarly agendas related to democracy. This thesis investigates governance and accountability of food and drug safety in China, a country with a political system that can be characterised as non-democratic and authoritarian. According to Weatherley (2007), in the era of Mao, China formulated a highly political control regime, a vertical authoritarian regime that emphasised one-party rule of the country and conducted strict political control over society and the market. With the economic reform begun in the 1970s, China began to pursue political and economic decentralisation. He and Thøgersen (2019) argue that even though China has not undergone a transition to democracy, the current regime is qualitatively different from the system that reformers inherited from the highly political control regime. In the post-Mao era, the Chinese state implemented a market-oriented economy with less government intervention. Meanwhile, the state carried out a series of innovations in the political system to keep pace with the development of the market economy. For instance, the state promoted consultative and deliberative mechanisms like the National People's Congress, allowing the public to engage in politics (He and Thøgersen, 2019); designed social policies catering to public preferences; improved the responsiveness of the states to citizens; fostered a serviced-oriented government (Zhang, 2013; Chen et al., 2017) and decentralised the downward power society, aiming to cultivate the development of social organisation and encourage media commercialisation (Stockmann, 2013, p. 14). In these ways, the Chinese state has improved their political capacity to govern society and consolidated political legitimacy in modern society. Nonetheless, it appears that very little structural political changes have occurred; these political reforms preserved the core elements of the authoritarian political system. The reins of society and the market are still tightly gripped by the Chinese communist party, the introduction of multi-level 
governance has not resulted in a decrease of state power or an increase in the freedom of citizens and the mainstream media are sponsored by the state to propagandise political achievements and to serve the communist ideology (Landry, 2008; Zhang, 2015). In essence, according to Zhu (2014), the political reforms just focused on a shift from a vertical authoritarian system that stressed the domain of a paramount leader acting through a vertical command channel with a fundamentally unified policy to a horizontal authoritarian system focusing on a multi-power base coordinated by the political system to reflect different interests and policies. The expectation of Western scholars that the introduction of a market economy and economic freedom would automatically lead to political freedom and a Western-style democracy appeared to be wrong. According to Tang (2016), while citizens may have severe critiques of Chinese policies, the increasing welfare of China and the regime-enhancing effects of economic prosperity are much greater than the regime-eroding effects.

How to understand public accountability in that context? According to many scholars, accountability in China is not primarily a public issue but an administrative one, aiming to enhance institutional efficiency instead of democracy. The political scientist Huamin (2013) argues that in the context of China, the ruling party stresses developing administrative accountability in which administrators are obliged to subject themselves to the scrutiny of those who have entrusted them with power - which is the centralised state and not the public - and they have to take responsibility for their performance. In line with this, other scholars argue that accountability mostly entails figuring out the nature of administrative errors and then finding means of correcting them (Benchun, 2010; $\mathrm{Lu}$ and Xue, 2011). The purpose of administrative accountability in China is to maximise administrative efficiency. When administrative actors do what they have to do, but do it poorly or inefficiently, managerial strategies such as punishment, better supervision and training can be proposed to improve administrative efficiency (Tao, 2005). In this context, argues So (2014), the local states of China are keen on building administrative accountability structures with civic engagement mechanisms to maintain the interests of the masses via new instruments to evaluate the performance of diverse state sectors, like social surveys, mass media and the internet. For instance, So (2014) shows that a local state designed the Democratic Review of Administrative and Business Style online system to enhance public engagement with their administrative bodies and to construct a social oversight function. The construction of horizontal accountability that diverse actors engage in is usually associated with electoral democracies. Nonetheless, in the non-democratic system of China it contributes to enhancing the responsiveness of local officials and to improving the efficiency of the bureaucratic system (So, 2014).

\subsection{Science and technology studies}


In food and drug safety accountability practices, experts play a major role as they develop instruments, norms and standards for safety and are important in implementing them and in supervising how they are used in practice. Therefore, to understand accountability practices, paying special attention to the role of experts is required, as well as the actual use of these standards. To that purpose I will introduce Science and Technology studies (STS), an interdisciplinary field defined by Felt (2017), entailing investigations of the institutions, practices, meanings and outcomes of science and technology and their multiple entanglements with the worlds people inhabit, their lives and their values. In short, STS studies the relationships between scientific expertise, society and politics from the idea that balanced relationships are important to the quality of society and democracy. For STS, understanding science and technology means interrogating not only how science and technology shape social life and the world around us but also how the latter, in turn, shapes developments in science and technology.

STS plays a critical role in understanding the development and implementation of policies. According to Felt (2017), STS raises important questions about the legitimacy of expert knowledge in democratic contexts: Who has a voice to make legitimate knowledge claims, who has the access to knowledge infrastructures, who defines problems and solutions, and who participates in imagining and shaping the future? Asking these 'who' questions points to concerns about the dynamics of exclusion, oppression, inequality and social justice in knowledge-intensive policy practices. STS scholars tend to proactively look for resistance to conventional knowledge orders, for dissident voices, for neglected knowledge and experiences and for alternative conceptualisations of problems and solutions and of progress and the future. Felt (2017) argues that reflection on the relationship of experts, the public and the state may articulate conflicts over specific knowledge claims. For instance, Moes et al. (2017) examined a remarkable lawsuit about health care rationing between a patient association and the Dutch National Health Care Institute, in which the patients sued the institute for misconduct against interstitial cystitis patients and challenged relevant clinical expertise.

Jasanoff (2017) has studied modern states as 'states of knowledge', whose practices of collective sense-making include the production and deployment of scientific knowledge (p.273). States exert power through authoritative knowledge-making, and citizenship includes the rights and obligations to contribute to and act upon these collective knowledge practices. Subsequently, Jasanoff examined the states of knowledge in the case of knowledge and political order in the European Environment Agency. To produce knowledge and define the political order about the environment in Europe, the European Environment Agency developed natural knowledge which is appropriate for use and dissemination as the official EU environmental information and then set up new policies, established the political order and incorporated these meanings of environmental knowledge into 
modern citizenship and civic responsibility to reshape risk perceptions and environmental behaviours of the public (Wateron and Wynne, 2004, p. 88).

The attentiveness of STS scholars to multiple, coexisting knowledge regimes and rationalities challenges an understanding of citizens as unknowledgeable and either permanently clueless or eternally educable. STS considers the public as knowledgeable citizens, processing information, learning and producing expertise when the situation demands it (Jasanoff, 2011). In STS, citizens are framed as epistemic actors and good governance entails that citizens as lay experts have to be taken seriously. Good governance entails inviting, respecting and incorporating the experiential knowledge and expertise of citizens to build trust, democracy as well as to improve institutional efficiency.

Nonetheless, these STS notions about epistemic citizenship are not yet widely adopted, and governing institutions tend to stick to the deficit model of the public (Wynne, 1993), regarding dissenters against the official epistemic consensus as cognitively impaired, with aims to shape citizens' compliance and to achieve political goals. Hess et al. (2008) argue that though the idea of public engagement has gained ground in STS research, controversies remain over what constitutes good public engagement in technical decisions, reflecting competing understandings of citizens as knowledgeable or in a state of deficiency. At the same time, experts are portrayed by constructivists as rational and active agents in building and protecting their epistemically privileged status through skilful boundary work in the fields of institutional logic and social interaction (Jasanoff, 1990). According to Collins (2014), citizens should not be treated as the same as experts in technical deliberations. As a result, political institutions narrow the imagination of expertise needed to address complex social concerns and do not attune to citizens' technical competencies (Jasanoff, 2017).

The research field of STS was established in the 1980s in Western democratic countries like the Netherlands, the UK, the USA and Germany and has become a more global field in the $21^{\text {st }}$ century. As a consequence, many studies of relationships between science, society and politics have focused on democratic contexts, where the call for more democratisation of scientific expertise has found fertile soil. As this study investigates food and drug safety in China, it is interesting to explore how science, society, and politics's relationships are discussed in the non-democratic context of China. To this end, I map the STS landscape of China. As the earliest relevant STS organisation in China, the Commission of Science, Technology and Industry for National Defence was set up in 1985 aiming to serve scientific decision-making with respect to economic development and the governance of society and foreign affairs to ensure that national policy goals are met (Simon and Goldman, 1989). Realizing the importance of science and technology to improve the scientific literacy of citizens and to advance the modernisation of China, the state established STS as a disciplinary field to promulgate scientific knowledge in 2001 (Ding, 2001). While the rise of STS in Western countries started as a grassroots critique about the entanglements of politics and science that developed into a firm academic position, 
the establishment of this commission showed that attention to the interactions between science, politics and society in China was a top-down movement, initiated by the central state. However, in this specific Chinese socio-political context, STS scholarship is developing.

Current well-known Chinese STS scholars - like Zhengfeng Li and Li Liu, working at Tshinhua University, and Fei Xu, employed at the University of Science and Technology of China - have studied the development of STS, science and technology policy and science popularisation policy in China (Chen et al., 2008; Jia and Liu, 2014; Li and Lu, 2018). According to Zhang (2015), in the post-Mao era, science and technology have always been a 'politicum': the ruling party and scientific community together lead public deliberation on collective actions (p.917). In her study of the credibility paradox in China's science communication, Zhang (2015) argues that science and technology in China are of major importance for achieving economic and political objectives. Since China's economic reform in 1978, science has been seen as a production force expected to stimulate economic activities and improve the people's living standards and not as a more or less independent knowledge institution. According to Zhang (2015), in 1995, to accelerate the process of science and technology, then-president Jiang Zemin formally proposed 'rejuvenating the nation through science and technology' as a national strategy in the National Science and Technology Conference held by CPC National Congress (p.917). Chen et al. (2008) and Liu et al. (2012) show that at that time massive science popularisation campaigns were organized to reduce low scientific literacy in Chinese citizens, to oppose folk beliefs and superstition and to serve communist ideology. In practice, China's science and technology system is highly centralised. Almost all regulatory decisions and funding can be traced back to a handful of ministerial-level organisations that are under the direct leadership of the State Council (Zhang, 2015).

Interestingly, in parallel to the STS development in the West, the Chinese government has realized the importance of public understanding of science to forge a knowledge economy. In the 2000 s, a series of laws and regulations were installed to promote science communication between scientists and citizens (Chen et al., 2008). For instance, in June 2002, the Law of the People's Republic of China on the Popularisation of Science and Technology was enacted to regulate the contents of science popularisation and the rights and duties of individuals, social organisations, relevant administrative units and governmental institutions involved in scientific popularisation. The law entails that citizens have rights to be educated regarding scientific knowledge and individual moral quality, and the schools are obligated to organise education activities related to science and technology popularisation (Chen et al., 2008; Li, 2011). Additionally, in March 2006, the outline of an action plan for improving scientific literacy for all (2006-2010-2010-2020) was issued by the state council of China, aiming to promote basic scientific literacy in China by means of education, dissemination and popularisation of science and technology by the middle of this century (Chen et al., 
2008). Nonetheless, as some STS scholars have noticed, science communication in China articulates a top-down approach and is entrenched with state directives and centralized control (Liu et al., 2012; Liang et al., 2019). According to Zhang (2015), experts in the Chinese media are often selected by the authorities for their 'policy compatibility', which means that science communication is a very specific form of policy engagement, aiming to justify political agendas (p.918). According to Wynne (2001), overshadowing science communication with political directives may result in public alienation. Sometimes if science communication is government-led, the public will refuse to trust the information that is communicated (Zhang, 2015). China is currently running into this issue, especially in the field of public health. The over-politicisation of science communication has frustrated public trust in the governance of food and vaccine safety. Informed by these theoretical lenses, 1 inquire into how public accountability of food and drug safety acquires meaning in Chinese public debates.

\section{Methodology}

This research deals with two cases, food and drug safety, and I chose a qualitative approach. While the details of specific methods are dealt with in the different chapters, here I will explain the rationale of my methodological choices. But first I will introduce the cases.

\subsection{Selection of cases: Baby food and vaccine safety incidents}

Over the last decade China has suffered from a series of safety incidents with respect to baby food. In September 2008, Sanlu, a baby company in the province of Hebei, adulterated infant formula with melamine, aiming to increase the protein content and earn more profits. This resulted in the death of six babies from kidney stones, and an estimated 12,892 babies were hospitalized. However, the behaviour of Sanlu was not exceptional. Government inspections revealed that this problem had existed to a lesser degree in infant formula from 21 other companies, including for instance Mengniu, Yili, Shengyuan, Guangming and Yashili. The issue raised a nationwide social panic and public distrust about domestic infant formula. According to the China Central Television 'Weekly Quality Report' survey in 2011, three years after this scandal, $70 \%$ of Chinese people still did not dare to buy domestic milk powder. Chinese citizens not only distrusted Chinese dairy manufacturers but also were sceptical about the food safety regulation system, public communication and the objectivity of experts. The distrust was fuelled by the fact that after a previous infant formula incident in Anhui province in 2004, the local Centre for Disease Control (CDC) had put Sanlu on the list of substandard milk power companies but revoked this decision on the grounds of staff error, and multiple national authorities issued a joint document requesting each local government to allow the sale of Sanlu infant formula nationwide (Pei et al., 2011). 
During 2007 and 2008, citizens were frustrated by the withholding of negative information about Sanlu infant formula by public health experts and authorities. A parent who complained to the local state in 2007 that his baby had fallen ill after consuming baby formula from Sanlu, and who never received any answer, posted his story online. Subsequently, Sanlu corporate contacted him, bought him off and deleted the negative information about the company's problem products (Mooney, 2008). In 2008, more and more consumers posted information about the contamination of Sanlu milk and subsequent kidney damage on the online system of the National Supervision, Inspection and Quarantine Administration, but there was no response either. In August 2008, experts from the Hebei Provincial Institute of Quality Inspection announced that Sanlu milk powers were qualified as safe again after official quality tests, and while experts in the National Health Administration confirmed that Sanlu milk powder was adulterated with melamine in 2008, they delayed the release of this information for one month (Mooney, 2008). According to Sina News (Wan, 2018), the scandal demonstrated not only fraud by the Sanlu milk company but also government-business collusion, non-responsiveness of the state and lack of public communication, all of which have destroyed public trust in infant formula safety and its regulation system (Bei, 2011). This incident and the response show food safety as a contested and public issue; this raises questions about how governance and accountability are discussed in China.

Vaccine safety issues have created public distrust in Chinese governance of public health as well. It started with several regional vaccine scandals in the 2010s. In 2010, it was reported that a lot of vaccine stock in Shanxi CDC were damaged by heat exposure. Though the damaged vaccines should have been immediately destroyed they were instead administered to children throughout the province, which resulted in deaths of several children and seriously injured many others (Liu, 2010). However, the experts at the Shanxi Provincial Health Department announced, after having investigated the casualties, that there was no relation between the death of the children and the vaccine, and they stated that vaccines throughout Shanxi province were safe (Liu, 2010). In 2013, 11 children in southern China died after hepatitis B vaccination. Parents related these deaths to vaccination, while medical doctors diagnosed them as a 'coupling symptom', refusing any relation to the vaccination ( $\mathrm{Li}$ et al., 2014) . That these incidents have a structural character becomes clear when on 18 March 2016 the Shandong police announced that they had arrested a mother and daughter suspected of illegally selling improperly stored vaccines worth more than 570 million yuan, involving 24 provincial-level regions. And the story about vaccine scandals is continuous in China. On 15 July 2018, China's Food and Drug Administration found that Changsheng Biotechnology had fabricated false production and inspection records in 2017, arbitrarily changing process parameters and equipment during the production of freeze-dried human rabies vaccines (Xinhua Net, 2019). Apart from that, substandard DPT vaccines (diphtheria, pertussis and tetanus) produced by the same 
company were administered to 215,184 Chinese children in 2018, and 400,520 substandard vaccines produced by the Wuhan Institute of Biological Products were sold in Hebei and Chongqing in 2018 (The Lancet, 2018). All these incidents have caused a lack of trust among citizens in vaccine safety and in drug-safety governance (Cao et al., 2018). In the media and among the public the widespread sale of illegal and fake vaccines has been attributed to deficient safety regulation, negative crisis response of public health authorities, collusion between officials and businessmen and malpractice of public officials. These vaccine scandals have not only sparked parental anger and distrust across the country but has also fuelled global concern (The Lancet, 2018).

Securing food and vaccine safety is matter of public health and authorities' credibility. Therefore, the Chinese government attaches equal importance to food and drug security. To deal with these incidents and restore public trust, a segmented model for safety regulation was introduced in 2004 (Ding and Sun, 2014). In this model the central state assigned responsibilities to different departments covering the whole food and drug industry chain: the commerce departments had to manage and guide the catering industry; the quality inspection departments had to supervise food and drug processing links and to disrupt illegal activities like using gutter oil to produce food; the Municipal Industry and Commerce Administration had to supervise the circulation of cooking oil and disrupt the illegal activities of the reprocessed gutter oil trade; the Food and Drug Administration had to supervise consumption and the Hygiene Administration had to strengthen risk monitoring and implement prompt detection (Jia and Jukes, 2013). However, while the segmented model was applied in both food and drug safety regulation, the differences in food and drug safety regulation should be stressed as well.

While the segmented regulation model appeared to work rather well for food safety, as food incidents became reduced, vaccine incidents continued to occur. Over the past fifteen years, the segmented regulation model has not only stressed the quality control of vaccines, but also advocated for medical autonomy during vaccination: physicians were allowed to interfere and overrule parents' preferences, aiming to prevent harm. While stressing medical authority in the relationship of doctors with parents, the regulatory model failed to notice the lack of state regulation with respect to the quality of vaccination services (Katz, 2002). Medical autonomy that focuses on doctors' rights and ignores parent demands harms bilateral trust between doctors and parents, especially during adverse reaction events induced by vaccination (Fadda et al., 2016). Parents have thus requested government interventions to secure the public's benefit. With ongoing vaccine-induced adverse events, the central state realized the importance of state intervention in vaccination and the differentiation of food and drug safety regulation. In 2019, the central state revised the Regulation on the Administration of Vaccine Circulation and Vaccination to strengthen the surveillance of vaccine safety, establish strict 
standards for vaccination and build information traceability in medical institutions (Wang and Ding, 2019).

This short overview of the many scandals in food and drug safety shows why I chose these cases to study governance and accountability of public health in China.

\subsection{A qualitative approach}

The aim of this study was to provide a better understanding of how governance and accountability of food and drug safety are publicly discussed and of how diverse stakeholders define the problem of safety crises, the responsibilities for those crises and the strategies to deal with them. To realise that aim, I chose a qualitative approach. To explore how Chinese academics and professionals have constructed the governance of drug safety and food safety as a public issue, I did a content analysis of their Chinese academic work, and to explore how parents, policymakers, public health experts and media professionals have defined drug and food safety as a public problem, I performed qualitative interviews.

For the content analysis of the work of academic and professional debates about governance of food and vaccine safety, I followed the methodology of a scoping review to summarise these research findings and to identify the research gaps in the existing literature. In line with these purposes, Arksey and Malley (2005) offer a five-stage framework to conduct a scoping review: identifying the research question, identifying relevant studies, selecting studies, charting the data and collating, summarizing and reporting the results. Informed by Arksey and Malley's methodological framework, I selected four Chinese databases for studying academic and professional debates about the governance of food and vaccine safety: China National Knowledge Infrastructure (CNKI), Baidu Scholar (BS), Wanfang database (WD) and Chongqing VIP (CVIP). More details on how I conducted both scoping reviews are provided in chapters 2 and 4.

While the scoping reviews provided insight into the academic perspectives on accountability for food and drug safety, it stimulated interest in how diverse stakeholders in everyday life consider this issue. To gain more insight into that, I conducted half-open interviews with diverse stakeholders, for instance citizens, journalists, local official, industrialists and public health professionals. The analysis of their stories added important insights to the analysis of debates in Chinese academia.

\subsection{Dilemmas and strategies in the fieldwork}

Performing a qualitative study in China, including fieldwork and interviews, is complicated. In practice, getting access to potential participants according to more or less standard procedures is not feasible due to the unique political context of China where the states are wary of field investigations for fear of negative reports, damage to their reputations and subsequent administrative accountability 
(Heimer and Thøgersen, 2006). Therefore, local officials are reluctant to be involved in research about sensitive topics like the accountability of food and drug safety and public trust. Additionally, according to Yang (1994), in Chinese society the cultural importance of social relationships entails that individuals maintain personal relationships through gift-giving when they ask a friend for a favour; in research this is a common method to get access to different participants. These characteristics of the Chinese context affected this research a lot.

Searching for participants by simply approaching people according to a specific sampling method, inviting them to participate, arranging informed consent and making an appointment, was not feasible as I especially wanted to interview public officials working in administrative hierarchical state institutions. It appeared that local officials rejected the invitation for an interview because they did not have official permission from the legal authorities or from their superiors as they were concerned about negative media reports, social criticism and reputational damage. So, making official appointments to get access to participants frustrated my fieldwork at the regional level of China.

In January 2018, I visited the Food and Drug Supervision Bureau (FDSB) in my home city. I then introduced myself, informed them of the purpose of the fieldwork and attempted to make appointments with staff there. Some of them were willing to be interviewed, but they argued that it should be approved by their leader prior to the interview. Subsequently, I visited the leader's office. However, the department leader rejected me immediately on the grounds that they were busy with the work of annual employee performance assessment and had no time for interviews. In a similar way, I failed to access any participants at local state institutions (fieldwork notes from YR, 12 January 2018).

Clinicians in hospitals were not willing to engage in an interview either, as they were busy with the task of vaccination and were not acquainted with me; therefore, they considered an interview irrelevant to their work.

In January 2019, I introduced my purpose of visiting and attempted to interview the doctor in the vaccination clinic after I made an appointment at the registration office (Gua-hao-chu) in a public hospital in Wuhan. The vaccination doctor told me 'we don't accept any interviews unrelated to our work, please do not interrupt our (vaccination) work and leave this office' (fieldwork notes from YR, 14 April 2019).

According to Yang (1994) and Heimer and Thøgersen (2006), fieldwork in China can be made possible if official permission from the states and informal permission from the local leaders are acquired. In China it is common that, prior to conducting an official fieldwork, research institutions and social organisations apply for official permission from the states. If, after evaluation of the topics, content and aims of investigation and the background of fieldwork organizers, the permission is given, researchers will obtain a formal letter of invitation to convince the local officials that they should be 
interviewed, support this fieldwork and provide data to fieldworkers (Heimer and Thogersen, 2006). However, for fieldwork launched by individuals without public funding support it is difficult to obtain this state approval. In that case, getting access to participants through informal relationship networks plays a key role in fieldwork, and I adopted that procedure as well. To obtain informal permission for interviews from the local leaders, one of my acquaintances served as a mediator, entailing that one person who kept good relationships both with the relevant leader in the local state and me helped to establish the first contact for interviews.

To obtain informal permission from the relevant local leaders, I invited my uncle, who has worked in the local state for several years and maintained a strong relationship with local officials, as a mediator to establish contacts with these leaders. I was then able to carry out interviews with their subordinates in departments after obtaining informal permissions from these leaders (fieldwork notes from YR, 07 March 2018).

In a similar way, we got access to the different relevant participants through 'acquaintance mediation' to build first contact with participants. Additionally, I included more participants' colleagues through the snowballing method to continue the fieldwork.

It is a standard in qualitative research to organise and ensure informed consent, to protect participants from any pressures by the study. Although participants had already agreed with the interview via the acquaintance mediation, I followed this rule. Prior to the interviews, I informed research participants about the research goals, methods, funding sources, expected outcomes, anticipated impacts of our study and the rights and responsibilities of participants, and I ensured the anonymity of the participants. Before the interview with local officials, they were privately informed by their superiors about not talking too much and not to provide negative information to 'outsiders'. The topic was considered more delicate as this research was launched in Europe. Also, experts in the risk assessment centre, the risk communication centre, the CDC and in state-owned hospitals were cautious when answering questions.

A dean asked one participant to leave the office for a talk privately when he was passionately articulating the details of how the staff perform food safety regulation in practice and deal with food safety crises. When this participant returned to the conversation, he kept cautious when answering questions and provided me with short information, not talking as much as he had a moment ago (fieldwork notes from YR, 11 March 2018).

According to Nojonen (2004), who studied the conducting of fieldwork in a low-trust society like China, the sensitivity of informants to these kinds of interviews can be related to the fact that they are non-authorised by the state, resulting in less trust and more cautiousness of participants. Local officers are restrained by their leaders to be involved in controversial topics for the concern of 
reputation damage and fear of carrying the blame. Chinese citizens generally distrust interviews conducted by a stranger and they are reluctant to openly express personal opinions about politics and policies for fear of unnecessary trouble. Realizing that participants may be stuck between the social obligation to their acquaintance to give an interview and the reluctance of their supervisors, I tried to spur participants to express their opinions freely: I conducted interviews in an informal environment, such as a tea bar, a restaurant or their home, instead of in their offices, and developed friendships through gift-giving. I also avoided taking interview notes in front of participants to mitigate their guardedness.

I invited several doctors to have a drink in the tea bar and gave them the red wine I brought from the Netherlands as gifts. They then wanted to share information in favour of my interview. During the interview, they expressed their opinions freely as in conversation with old friends (fieldwork notes from YR, 15 March 2018).

Prior to the interview, I kept all the questions in mind, to avoid looking down at the question list now and again. Meanwhile, I acted as a good listener without taking notes during the interview. After each interview, I took detailed notes immediately, which allowed to record the interview contents accurately (fieldwork notes from YR, 13 January 2019).

A qualitative approach to accountability for food and drug safety is fruitful for getting in-depth insights into the diverse meanings of accountability and trust, responsibility for incidents and the adequacy of responses to incidents. Despite all the difficulties mentioned above, 1 was able to collect interesting data through some strategies such as establishing private relationship with respondent through 'acquaintance acting as a mediator to establish the first contact', gift-giving to befriend them and avoiding taking notes in the front of participants. Nonetheless, the methodological difficulties also stimulated reflection on the methodological and ethical standards for qualitative research in a non-democratic context like China.

\section{Outline of the book}

In this introduction chapter, I have introduced the main research question, the theoretical background and the overall methodology. In the other chapters I will present the results of the four different studies. In chapter 2, I will present an analysis of the scientific discourse on the construction of food safety governance as a public issue in China. To that purpose, I conducted a scoping review methodology of Chinese academic databases in the format of a document analysis. The analysis shows how Chinese scholars study and discuss public accountability of food safety in terms of supervision and accountability, risk assessment and transparency. In chapter 3, I conduct a qualitative analysis of the narratives of diverse stakeholders in the food safety crisis and the 
governance infrastructure a decade after the melamine crisis. I interviewed, for instance, mothers, government officials, the dairy industry, journalists and experts in China. The chapter shows how different stakeholders construct the public accountability of food safety very differently. In chapter $\mathbf{4}$, I turn again to academia. I conducted a scoping review to exhibit how scholars study and discuss vaccine hesitancy in China following a series of vaccine incidents emerging over the last decades. This chapter maps which potential solutions Chinese scholars put forward and how they relate vaccine hesitancy to parent beliefs, to vaccine safety and its control system and to inappropriate medical conduct. In Chapter 5, 1 presents an analysis of how different stakeholders consider vaccination hesitancy in China and public accountability and governance of vaccine safety. I analysed interviews with parents, public health and media professionals and online vaccination narratives. In a similar way as in chapter 3 , the analysis again shows very different perspectives between experts and lay people regarding vaccination hesitancy. In chapter 6, I summarise and compare the findings, go into the strengths and limitations of the study and discuss the results in the context of relevant literature about public accountability for food and drug safety in China. I also reflect on the lessons of this study about other problems in public health, like the Covid-19 pandemic.

\section{References}

Arksey, H. and O'Malley, L., 2005. Scoping studies: Towards a methodological framework. International Journal of Social Research Methodology, 8(1), pp. 19-32.

Bei, Q., 2011. Did the melamine scandal make Chinese food safety industry feel ashamed? Sina Blog. 1 August. http://blog.sina.com.cn/s/blog_74a7ca7c0100x0x0.html

Benchun, H., 2010.A study of the development of China's administrative accountability system. Public Administration \& Law, 1(3), pp.12-15.

Bovens, M., Schillemans, T., Goodin, R.E., 2014. Public accountability. In Bovens, M., Robert E. Goodin,R.E. and Schillemans, T, ed. The Oxford handbook public accountability. Oxford University Press. pp.1-22.

Cáceres, M., 2018. Vaccine Scandal in China Crosses 'Moral Bottom Line'. Vaccine. https://templetonwatch.blogspot.com/2018/08/vaccine-scandal-in-china-crosses-moral.html

Cao, L., Zheng, J., Cao, L., Cui, J. and Xiao, Q., 2018. Evaluation of the impact of Shandong illegal vaccine sales incident on immunizations in China. Human Vaccines \& Immunotherapeutics, 14(7), pp. 1672-1678.

Chen, B., Zhang, J.M., Jiang, Z., Shao, J., Jiang, T., Wang, Z., Liu, K., Tang, S., Gu, H. and Jiang, J., 2015. Media and public reactions toward vaccination during the 'hepatitis $\mathrm{B}$ vaccine crisis' in China. Vaccine, 33(15), pp. 1780-1785.

Chen, F., Shi, Y. and Xu, F., 2008. An analysis of the public scientific literacy study in China. Public Understanding of Science, 18(5), pp. 607-616.

Chen, X., Yang, H. and Dai, B., 2017. Analysis of national food poisoning from 2008 to 2015. China Food Safety. 15 September. http://www.cnfoodsafety.com/2017/0915/24624.html

Collins, H., 2014. Rejecting knowledge claims inside and outside science. Social Studies of Science, 44(5), pp. $722-735$.

Devaney, L., 2016. Good governance? Perceptions of accountability, transparency and effectiveness in Irish food risk governance. Food Policy, 62, pp. 1-10.

Ding, B., 2001. Constructivism and science education reform facing the 21st century. Comparative Education Research, 3(8), pp. 7-11. 
Ding, H. and Sun, W., 2014. From administrative supervision to social co-governance: A system breakthrough in food safety supervision: Based on the perspective of network analysis. Journal of Jiangsu Administration Institute, 1(6), pp. 111-117.

Dubnick, M.J., 2014. Accountability as a cultural keyword. In Bovens, M., Robert E. Goodin,R.E. and Schillemans, T, ed. The Oxford Handbook of Public Accountability. Oxford University Press. pp.23-38.

European Monitoring Centre for Drugs and Drug Addiction., 2019. Drug-related deaths and morality in Europe. https://www.emcdda.europa.eu/system/files/publications/11485/20193286_TD0319444ENN_PDF.pdf

Fadda, M., Galimberti, E., Carraro, V. and Schulz, P.J., 2016. What are parents' perspectives on psychological empowerment in the MMR vaccination decision? A focus group study. BMJ Open, 6(4), e1011773.

Felt, U., 2017. Making knowledge, people and society. In The Handbook of Science and Technology Studies. Mit Press. pp. 254-465.

He, B. and Thøgersen, S., 2010. Giving the people a voice? Experiments with consultative authoritarian institutions in China. Journal of Contemporary China, 19(66), pp. 675-692.

Heimer, M. and Thøgersen, S., eds., 2006. Doing Fieldwork in China. University of Hawaii Press.

Hess, D., Breyman, S., Campbell, N. and Martin, B., 2008. Science, Technology and Social movements. In Hackett, E.J., Amsterdamska, O., Lynch, M. and Wajcman, J. ed. The Handbook of Science and Technology Studies (third ed.). The MIT Press. pp. 473-498.

Horstman, K., 2015. Struggling with science and democracy: Public health and citizenship in The Netherlands. In Health and Citizenship. Routledge. pp. 191-208.

Huamin, Z., 2013. Dilemmas and routes on the rule of law of the administrative accountability in China. Public Administration \& Law, 1(3), pp.12-17.

Huang, W., 2009. Interpretation of the Food Safety Law. Journal of Law, 6(3), pp. 148-150.

Jasanoff, S., 1990. American exceptionalism and the political acknowledgment of risk. Daedalus. 119(4), pp. 61-81.

Jasanoff, S., 2011. Designs on Nature: Science and Democracy in Europe and the United States. Princeton University Press.

Jasanoff, S., 2017. Science and democracy. In: Felt, U., Fouche, R., Miler, C.A. and Smith-Doerr, L. ed. The Handbook of Science and Technology Studies (Fourth ed.). Mit Press. pp. 259-288.

Jia, C. and Jukes, D., 2013. The national food safety control system of China - A systematic review. Food Control, 32(1), pp. 236-245.

Jia, H. and Liu, L., 2014. Unbalanced progress: The hard road from science popularisation to public engagement with science in China. Public Understanding of Science, 23(1), pp. 32-37.

Kang, Y., 2019. Food safety governance in China: Change and continuity. Food Control, 106, pp. 1-8.

Katz, J., 2002. The Silent World of Doctor and Patient. JHU Press.

Kedia, B., 2018. China's vaccine scandal - Why we should care too. Health Express.3 April. https://www.orfonline.org/expert-speak/43238-china-vaccine-scandal-why-should-care-too/

Landry, P.F., 2008. Decentralized Authoritarianism in China. Cambridge University Press.

Lee, C.K. and Zhang, Y., 2013. The power of instability: Unraveling the microfoundations of bargained authoritarianism in China. American Journal of Sociology, 118(6), pp. 1475-1508.

Li, C., 2009a. Determination of Sudan dyes and para red in duck muscle and egg by UPLC. Chromatographia, 70(1), pp. 319-322.

Li, K., 2009b. A comparative study of the Food Safety Law and the food sanitation law. Journal of Sichuan Administration College, 3(1), pp. 57-59.

Li, M., Liu, X. and Zhang, L., 2014. Hepatitis B vaccine adverse events in China: Risk control and regulation. Human Vaccine Immunotherapy, 10(10), pp. 2992-2993.

Li, X., 2011. Development of moral education and reform of higher education in China. Journal of Yanbian University (Social Sciences), 3(3).pp. 1-7.

Li, Z. and Lu, X., 2018. Reflections on STS in mainland China: A historical review. East Asian Science, Technology and Society: An International Journal, 12(2), pp. 185-196. 
Liang, J., Liu, X. and Zhang, W., 2019. Scientists vs laypeople: How genetically modified food is discussed on a Chinese Q\&A website. Public Understanding of Science, 28(8), pp. 991-1004.

Lin, L., 2019. The responsible person of the food safety office of the state council answered a reporter's questions on 'opinions' of the CPC Central Committee and state council on deepening reform and strengthening food safety work. China News Portal. 22 May. http://www.chinanewsportal.com/news/2019/0522/0732/5d411442968c28f6a380b8a4

Liu, P., 2010a. Tracing and periodizing China's food safety regulation: A study on China's food safety regime change. Regulation \& Governance, 4(2), pp. 244-260.

Liu, W., 2010b. The truth I know about the Shangxi Vaccine scandal. Oriental Morning Post. 22 March. http://pic.people.com.cn/GB/31655/11193851.html

Liu, X., Tang, S. and Bauer, M.W., 2012. Comparing the public understanding of science across China and Europe. In: Bauer, M.W., Shukia, R. and Allum, N. ed. The Culture of Science: How the Public Relates to Science across the Globe (First ed.).Routledge. pp. 139-157.

Lu, F. and Wu, X., 2014. China food safety hits the 'gutter'. Food Control, 41, pp. 134-138.

Lu, Y. and Xue, C., 2011. The power of the purse and budgetary accountability: Experiences from subnational governments in china. Public Administration and Development, 31(5), pp. 351-362.

May, P.J., 2007. Regulatory regimes and accountability. Regulation \& Governance, 1(1), pp. 8-26.

Moes, F., Houwaart, E., Delnoij, D. and Horstman K., 2017. Contested evidence: A Dutch reimbursement decision taken to court. Health Economics, Policy and Law, 12(3), pp. 325-344.

Mooney, P., 2008. The story behind China's tainted milk scandal. US News. 9 October. https://www.usnews.com/news/world/articles/2008/10/09/the-story-behind-chinas-tainted-milk-scandal

Morris, N., 2019. Chinese vaccine scandal triggers share price hike for blockchain solutions. Ledger Insights. https://www.ledgerinsights.com/blockchain-solution-chinese-vaccine-scandal/

Nojonen, M., 2004. Fieldwork in a low-trust (post-) communist society. In Fieldwork in Transforming Societies. Palgrave Macmillan. pp. 157-176.

Pei, X., 2011. The China melamine milk scandal and its implications for food safety regulation. Food Policy, 36(3), pp. 412-420.

Penders, B. and Nelis, A.P., 2011. Credibility engineering in the food industry: Linking science, regulation and marketing in a corporate context. Science in Context, 24(4), pp. 487-515.

Peters, G., 2014. Accountability in public administration. In: Bovens, M., Robert E. Goodin,R.E. and Schillemans, T, ed. The Oxford handbook public accountability. Oxford University Press. pp.211-225.

Simon, D.F. and Goldman, M., eds., 1989. Science and Technology in Post-Mao China (No. 5). Harvard University Asia Center.

Snyder, F., 2015. Food Safety Law in China: Making Transnational Law. Brill.

So, B.W.Y., 2014. Civic engagement in the performance evaluation of the public sector in China: Building horizontal accountability to enhance vertical accountability. Public Management Review, 16(3), pp. 341-357.

Song, D., 2015a. Explanation on "Amendments (Drafts) to 26 Laws including the "Pharmaceutical Administration Law of the People's Republic of China" '. Government report presented at the 14th meeting of the Standing Committee of the 12th National People's Congress on 20 April 2015. Bulletin of the Standing Committee of the National People's Congress of the People's Republic of China, 3, pp. 649-652.

Song, S., 2015b. Challenges to China after becoming an upper-middle income country. The Chinese Economy, 48(1), pp. $1-4$.

Stockmann, D., 2013. Media Commercialization and Authoritarian Rule in China. Cambridge University Press.

Tang, W., 2016. Populist Authoritarianism: Chinese Political Culture and Regime Sustainability. Oxford University Press.

Tao, S.O.N.G., 2005. On the Definition of Administrative Accountability. Journal of Shenzhen University (Humanities \& Social Sciences), 2(3), pp.23-25.

The Lancet, 2018. Vaccine scandal and confidence crisis in China. The Lancet, 392(10145), p.1. 
The National Health Commission, 2010. There is no relation between vaccination and coupling. 26 March. http:/www.nhc.gov.cn/wjw/jbyfykz/201304/9849294753e24c0193a148fba47509dc.shtml

Wan, L., 2018. Ten-year review of the melamine incident: the top five milk powder brands are all imported. Sina Finance.01 October. http://finance.sina.com.cn/china/gncj/2018-08-01/doc-ihhacrce6725430.shtml

Wang, Y. and Ding, Y., 2019. How can China solve the problem of bad vaccines after Changchun Changsheng? Biotechnology Law Report, 38(4), pp. 224-228.

Warren, M.E., 2014. Accountability and democracy. In Bovens, M., Robert E. Goodin,R.E. and Schillemans, T, ed. The Oxford handbook public accountability. Oxford University Press. pp. 39-54.

Wateron, C. and Wynne, B. 2004. Knowledge and political order in the European Environment Agency. Political Science, 10. pp. 14-20.

Weatherley, R., 2007. Politics in China since 1949: Legitimizing authoritarian rule (Vol. 11). Routledge.

World Health Organization, 2008. International health regulations (2005). World Health Organization. https://www.who.int/ihr/publications/9789241580496/en/

World Health Organization, 2015. WHO's First Ever Global Estimates of Foodborne Diseases Find Children under 5 Account for Almost One-Third of Deaths. 3 December. https://www.who.int/news-room/detail/03-12-2015-who-s-first-ever-global-estimates-of-foodborne-dis eases-find-children-under-5-account-for-almost-one-third-of-deaths

Wynne, B., 1992. Public understanding of science research: new horizons or hall of mirrors. Public Understanding of Science, 1(1), pp.37-43.

Wynne, B., 1993. Public uptake of science: a case for institutional reflexivity. Public understanding of science, 2(4), pp.321-337.

Wynne, B., 2001. Creating public alienation: Expert cultures of risk and ethics on GMOs. Science as Culture, 10(4), pp. 445-481.

Xinhua Net, 2019. China: Tougher law on vaccine administration will go into effect in December 2019. Business \& Human Rights Resource $\quad$ Centre. 29 June. https://www.business-humanrights.org/en/china-changsheng-biotechnology-reportedly-sold-250000-fa ulty-vaccines-ordered-to-stop-production-after-outrage

Yang, M.M.H., 1994. Gifts, Favors and Banquets: The Art of Social Relationships in China. Cornell University Press.

Yee, W.H., and Liu, P., 2019. Control, coordination, and capacity: Deficits in China's frontline regulatory system for food safety. Journal of Contemporary China, pp. 1-16.

Yu, W., Liu, D., Zheng, J., Liu, Y., An, Z., Rodewald, L., Zhang, G., Su, Q., Li, K., Xu, D. and Wang, F., 2016. Loss of confidence in vaccines following media reports of infant deaths after hepatitis $\mathrm{B}$ vaccination in China. International Journal of Epidemiology, 45(2), pp. 441-449.

Zhang, J.Y. 2015. The credibility paradox in China's science communication: Views from scientific practitioners. Public Understanding of Science, 24(8), pp. 913-927.

Zhang, X., Zhao, H., Xue, Y., Wu, Z., Zhang, Y., He, Y., Li, X. and Yuan, Z., 2012. Colorimetric sensing of clenbuterol using gold nanoparticles in the presence of melamine. Biosensors and Bioelectronics, 34(1), pp. 112-117.

Zhang, Z., 2013. An analysis of China's energy demand and supply policy framework. Wiley Interdisciplinary Reviews: Energy and Environment, 2(4), pp. 422-440.

Zhu, X., 2014. Mandate versus championship: Vertical government intervention and diffusion of innovation in public services in authoritarian China. Public Management Review, 16(1), pp. 117-139. 


\section{Chapter 2}

Constructing the accountability of food safety as a public problem in China: A document analysis of Chinese scholarship, 2008-2018

Published as Yang, R., Horstman, K., \& Penders, B. (2020). Constructing the accountability of food safety as a public problem in China: a document analysis of Chinese scholarship, 2008-2018. Journal of Chinese Governance, 1-27. 


\begin{abstract}
Incessant food safety scandals in China have given rise to a loss of public trust in food safety, stimulating a series of studies focusing on food safety governance, accountability, and trust restoration. Against this backdrop, Chinese scholars are keen to reflect on different strategies for ensuring food safety public accountability and credibility, presenting different perspectives on issues like responsibility, trust, risk communication, and transparency. In this paper, we aim to get more in-depth insight into how Chinese scholarly debates co-construct public accountability for food safety as a public issue. We selected 51 articles from 10,790 candidates drawn from four Chinese academic databases for content analysis.

Drawing from political theories on public accountability as well as science and technology studies, the analysis shows that arguments for a specific public accountability model (more or less centralised, more or less stakeholder participation are intertwined with the specific role of scientific expertise (more or less authoritative, more or less democratising). As such, the analysis shows how scholarly debates on public accountability for food safety in China co-construct a public forum for discussing supervision and accountability, risk assessment, and transparency.
\end{abstract}




\section{Introduction}

China, as it rapidly transitions from a preindustrial to a largely industrial and, in certain aspects, even post-industrial state, provides a fascinating window into the process of rapid modernisation, in which various forms of risk are concerned. In the context of public health, such risks exist in various forms, one of which are those associated with food and food safety (Yan, 2012). China has arguably been more affected by food safety risks than many other countries (Jiang \& Zhu, 2013; Lam et al. 2013; Lu $\& \mathrm{Wu}, 2014)$. Multiple incidents regarding food safety contamination and poisoning have been repeatedly exposed over the past few years (Zhang, 2005; Pei et al, 2011), the most famous of which is the melamine baby formula scandal in 2008, better known as the Chinese Milk Scandal. This scandal resulted in 39,965 infants requiring some form of medical attention, 12,892 of whom were hospitalised, and four of whom died. Unsurprisingly, these incidents resulted in a public trust crisis in the dairy industry (Yang, 2012).

While such numbers were disturbing, the social consequences of such incidents and scandals remain unclear - as do (changes to) the structures in place to help guarantee food safety at large in China. In the Unite State (US) and European Union (EU), existing institutional structures include national and supranational agencies, such as the Food and Drug Administration (in the US) and the European Food Safety Authority (in the EU), where are both subject to democratic control while being simultaneously supported by the assessments of scientists and other experts (Meffitt, 2010; Balla, 2017; Busuioc and Rimkute, 2019). These socio-technical and socio-political arrangements have evolved to allow for various forms of public participation, yet all are tailored to Western liberal democratic political traditions.

Against this background, we raise questions as to how the governance of food safety is constructed as a public problem in China. More concretely, we will ask how the melamine baby scandal, and especially accountability in this scandal, are constructed in Chinese public and academic debate, which includes the different roles and responsibilities of associated institutions. To that end, we will first introduce the theoretical framework regarding public accountability and governance as well as certain conceptual devices from science and technology studies that form the basis for our analytical focus. We subsequently detail the methodology behind selecting the Chinese literature included in our analysis and the analytical frames employed. We present our results in three sections: accountability infrastructures; risk communication and transparency; and experts and risk assessment. Then, we present a summary and conclusion of the arguments and frameworks employed in Chinese academia and the value which they hold as research resources.

\section{Theoretical perspective of public accountability}


Bovens et al. (2014) argue that the concept of public accountability refers to matters of public concern that are dealt with in a public, open, and transparent manner (2014, p. 1-18). Many theories related to public accountability claim that, in many countries, government (legalistic, top-down) is becoming increasingly replaced by governance (societal, bottom-up) which results in an accountability deficit. Bovens and Flinders (2014, p. 663) summarise the 'conventional wisdom' contained in such works in the following four steps:

1. The transition from government to governance has undermined traditional mechanisms of democratic accountability.

2. As a result, politicians have become more untrustworthy, bureaucratic, and less responsive.

3. Any individual or organization that argues against greater accountability must have something to hide.

4. New modes and mechanisms of accountability therefore need to be implemented, to close the accountability gap.

Flinders (2014) is critical with respect to this conventional wisdom, and he argues that, before introducing new mechanisms of accountability, we need to understand the dynamics of accountability. Accordingly, he argues for closing the 'understanding gap' to the same extend as the accountability gap. In line with Flinders, Bovens and Schillemans (2014) argue that it is important to study and design meaningful forms of accountability. The increasing focus on public accountability has produced not only openness and transparency but also 'excessive costs, red tape, and negative effects of public values, such as effectiveness, efficiency, trust and learning' (Bovens \& Schillemans, 2014, p.674). They argue that scholars should study 'what types of accountability are relevant and the conditions and contexts in which they are effective' (p. 675). Instead of taking a deficit of public accountability for granted and introducing new technologies for control, they promote reflection on the issue of accountability to design new, relevant types of public accountability that are in line with active and dominant social values.

Papadopoulos (2014) distinguishes several dimensions of accountability, including the different accountors (who is accountable?), different account-holders (to whom are they accountable?), different aspects of government operations (for what are they accountable?) and different mechanisms (how are they accountable?). Klijn and Koppenjan (2014) conceptualize public accountability as institutionally differentiated: different accountability practices operate in different regulatory and accountability systems. In a democratic regime, multi-level accountability mechanisms and standards for accountable behaviour and performance co-exist, and accountability is embedded in more complex networks than in traditional policymaking and public service delivery. In a bureaucratic regime, public managers are vertically accountable to their supervisors and political goals. Alternatively, public officials in network situations have to consider other stakeholders in a horizontal 
mechanism of accountability. Reflecting on accountability in the context of crises, Kuipers and ' $\mathrm{T}$ Hart (2014) argue that crises generate public disquiet as well as trigger an inquiry and communication forum in which stakeholders exhibit various speculations, interpretations, and debates related to the performance of relevant political actors and management strategies in this crisis. Questions related to the performance of government result in a loss of confidence in the political body. As a response, regulatory bodies tasked with oversight are often authorised to investigate incidents, and they perform empathy and responsiveness as well as disclose relevant information to restore trust. Drawing from these conceptualisations of public accountability, we identified four key themes for our analysis: supervision systems, accountability systems, risk communication, and risk assessment. This aligns with Chinese scholars who consider the implementation of supervision, the distribution of power and responsibility among public institutions and actors, information transparency, and crisis response as pivotal determinants of accountability conduct as well (Zhang \& Han, 2018). Additionally, accountability requires transparency, and the availability of information and risk assessments is one of the prerequisites for the accountability process (Lai, 2014; Xu et al., 2014).

Furthermore, in science and technology studies (STS), scholars have studied how scientific expertise mediates the ideas, methods, and practices of risk governance and public accountability. After all, scientific instruments play a major role in framing and assessing risks, thereby merging science and politics under the banner of accountability (Weingart, 1999). Jasanoff (2007) has argued that public accountability not only requires designing technical approaches to risk assessment but also doing justice to diverse meanings of risk and safety as well as mobilising diverse voices. How such voices are taken into account, and how diverse tools, instruments, and metrics produce accounts accordingly and for whom is an area of continuous concern within the STS field (Adams, 2016; Penders, 2018). Studying the dynamics of trust and credibility is important in acquiring insight into how assertions of expertise can attune to, incorporate, or side-line public values and how expert authority in politically charged environments relates to the public and politics.

Informed by a conceptual understanding of public accountability in western and Chinese academia, we subsequently focus on the supervision model, the accountability structure, information transparency, and risk assessment in the study of public accountability in China. In this paper, we analyse public debates on public accountability for food safety in China, focusing on how public accountability is discussed and acquires meaning in this context.

In the following section, we report on the selection process for the documents included in this analysis and the criteria for doing so. We subsequently present the results of our document analysis and, finally, discuss the results in the context of scholarly debates on public accountability.

\section{Methodology}


This paper aims to provide insight into how, through scholarly debates, the governance of food safety and public trust in China evolved into a public problem of accountability as well as how this accountability problem has been characterised in the melamine milk scandal in 2008. This includes asking which actors beyond the Chinese government were addressed and how responsibilities and accountabilities were scholarly distributed in this scandal. To diagnose the rise of food safety as a public problem in China, we focused on Chinese scholarly and grey literature, the most likely source of relevant debates and conversations, published in and after 2008. While Chinese scholarly literature is an underused resource in research (Alemanno, 2015), it has become increasingly accessible to global scholars through the availability of literature databases. For this study, we consulted four China Databases: China National Knowledge Infrastructure (CNKI), Wanfang Data (WD), Chongqing VIP (CVIP), and Baidu Scholar (BS). These index Chinese journal articles as well as grey literature, including government reports and public commentaries. Such research infrastructure is relatively new in China, with CNKI being established in 1999, WD and CVIP in 2000, and BS as recently as 2014. Search strategies differ slightly from Western literature databases in that not all databases offer similar search features. As a result, despite seeking alignment as much as possible, the following differences exist between the aforementioned search strategies: in CNKI, we searched for scope, including title and abstract; in BS, we searched for title and abstract; and, in CVPI and WD, we searched for keywords.

Our search strategy was centred on issues of public accountability in food safety. Accordingly, we aligned the aforementioned public accountability conceptualizations with terminology actually used in Chinese academic writing. These include supervision models (监管模式 supervision system), structures of accountability（问责结构 accountability systems), information disclosure and transparency (信息揭露和透明 risk communication), and the expert risk assessment model (专家风 险评估 risk assessment) ${ }^{1}$.

To achieve maximum sensitivity and capture the most relevant literature, keywords were selected to incorporate each of the four themes, and included sources discussing relevant actors in food safety, (government) agencies and their relationships with other actors, policy research and new strategies for public participation, risk assessment strategies and models, and information release and disclosure of food safety.

The identification of the best keywords required an initial close reading of a random sample of papers, after which the comprehensive search strategy could be devised. The keywords used are listed in Table 1 (see Appendix 1). Publications containing at least one search term related to one of the five

1. In all following sections, we will use the more common terminology. 
themes were selected at this stage of the search. Subsequent inclusion and exclusion criteria are shown in Table 2 (see Appendix 1).

Using the search strategy described above, we identified 10,790 papers from the four databases, out of which 8,311 papers were excluded because they were duplicates present once or multiple times in one or more of the four databases; thus, we resulted in 2,479 papers (877 from CNKI, 608 from CVIP, 522 from WD, 472 from BS). Of these 2,479, titles and abstracts were screened to assess whether the papers fit the inclusion criteria, resulting in 2,414 papers being excluded. and 65 papers being selected for full-text screening. Out of these 65 articles, nine were excluded because they focused on microbiological technology, seven were excluded because they focused on EU or US food safety governance, and three government reports were excluded because they only mentioned food safety briefly in their conclusions. We excluded one article because its content overlapped with another paper included in this study. ${ }^{2}$ After full-text screening of the remaining ones, 45 were included, and their bibliographies were checked to identify further relevant papers. Through this, an additional six articles were identified, bringing the total amount of articles to be included in this analysis to 51. Figure 1 displays this selection process, and Appendix 2 and Appendix 3 lists all the sources, including an overview of the disciplinary character of those engaged in this discussion (e.g. affiliation and expertise of author and theory and methodology of the article).

Most of these studies were published after 2008. They focus on the issues of simultaneous supervision and accountability (regulation and accountability, $\mathrm{n}=17$ ), information disclosure (food safety communication, $\mathrm{n}=19$ ), and expert risk assessment (risk assessment models, $\mathrm{n}=15$ ) (see Appendix 2 for more details). The papers selected for inclusion disagree with one another. In this review, we treated them as comprising the public struggle for attention and credibility, supporting particular diagnoses the problems and solutions as well as how they are to be understood in the construction of public accountability of food safety. The subject matter under review is not merely a collection of descriptions but a series of political arguments and tools. Our review will therefore contextualise these political statements and situate them on the scholarly debate.

2. The moral connotation of this, and whether or not this qualifies as plagiarism or duplication, is not the subject of this paper. 


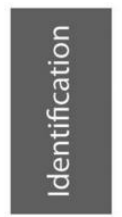

Articles identified through search (BS \& CNKI \& WD \&VIP) [n=10790]
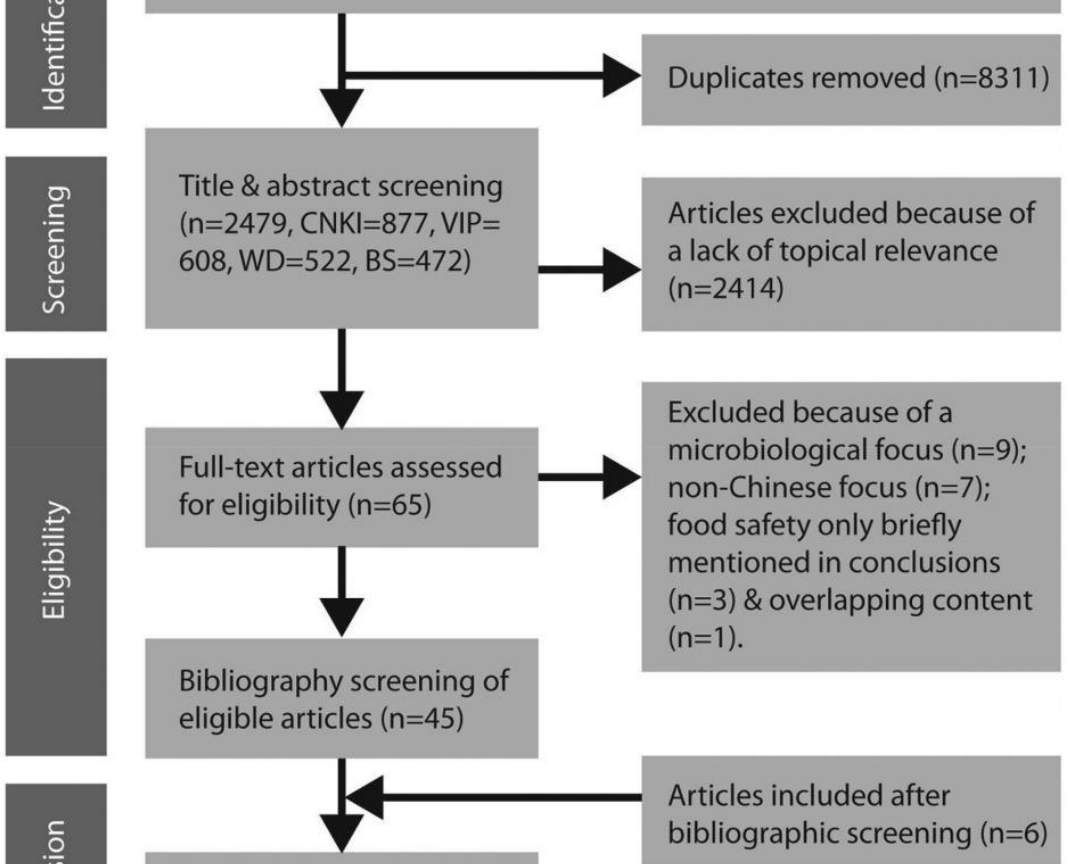

Final literature sample

$(n=51)$

Figure 1. Document selection process

\section{Results}

In this section, we present the results of the analysis of debates on accountability for food safety in Chinese academia. We present these results in three parts. First, we show how the accountability infrastructures, especially the relationship between diverse institutional actors, are discussed in the context of the Chinese food safety governance. Second, we show how scholars discuss risk assessment procedures, especially the role of experts in this regard. Third, we consider how risk communication and transparency come into play regarding food safety governance, and, in the fourth and final part, we address how scholars manage the issue of public accountability in the context of broader notions of societal trust.

\subsection{Centralised and decentralized governance systems}

One of the main themes in the literature is the development of the governance of food safety in China. In 1954, as a response to preventive, routine health supervision and infectious disease control, in the 
context of the old command regime in China, a command-control approach was implemented to ensure 'food hygiene', establishing the nationwide legal and supervisory status of the health administration. Sociologist Deng (2010) praised this system, arguing that the top-down command regime brought about positive effects in food hygiene supervision. Indeed, empirical research reveals a substantial drop in the number of people who suffered from food poisoning from 1,861 in 1991 to 513 in 2001 (Chinese Ministry Of Health, 2005). However, this system of public accountability has been increasingly criticised. For instance, political scientists Liu and Zhang (2010) argued that, with the rapid development of China's food industry, its scope has unduly extended to agriculture, agricultural product processing, food manufacturing, food distribution, and the catering industry. According to Liu (2010), a series of food safety scandals with severe health consequences underlined the idea that the traditional food hygiene approach, focused mainly on catering and consumption, had become increasingly outdated and had to be replaced by the universal notion of 'food safety'.

As a result, a new segmented governance model for food safety control was put in place in 2004. It aimed to respond to the complexity of food safety chains as well as new food safety issues, among which the Melamine Milk Scandal (also referred to as the Big Headed Babies scandal) in 2004 was one of the most severe (Hai, 2004). The new multi-sectoral model required that different state stakeholders assume responsibility for food safety in different phases of the food chain: the Agricultural Supervision Department was responsible for the food safety of primary agricultural products, the Quality Supervision Department is responsible for the food processing sectors, Industry and Commerce Administration was responsible for food circulation, the Ministry of Public Health was responsible for the catering industry, and the Food and Drug Administration was responsible for overall oversight, coordination, and organisation (Ma, 2007).

Several public policy scholars argue that this multi-sectoral governance approach was unable to clearly delineate the boundaries between the different domains of accountability (Wang and Mao, 2008; Yan et al., 2009; Yang, 2012). As a result, they argue, food safety governance suffers from an unclear distribution of power, leading to both power-overlaps and power-vacuums. On top of this, the system suffers from very ineffective administrative load.

This accountability problem can be alleviated, or so it is regularly suggested in mainstream Chinese media, as well as scholarly debates, through further centralising the system. Such centralisation could take shape in three different ways. Public policy experts Wang et al. (2009) argue that the distinct supervising bodies can be reunified into an independent agency, tasked with monitoring food safety at every level of the food chain. Fan (2008) argues, drawing from examples in the US and Japan, that the responsible agencies can be divided based on different food categories, with a single agency responsible for the entire food chain in that category. Finally, food policy experts Zhang and Sun (2008) and Zhang (2007), focusing mostly on the grey areas currently 
characterised by overlaps or vacuums of power, argue that, for these situations specifically, a separate entity is required. However, Liu (2010) critiques these three above scholars, proposing additional oversight bodies and arguing power should be centralised into both agriculture department and market supervision department by eliminating supervisory bodies.

Wang et al., Fan, Zhang, and Sun, Zhang, and Liu et al., although in different ways, call for greater centralisation to overcome these unclear accountability boundaries. Wei (2013), Lai (2013), and Wang (2007) oppose this call. Even if centralisation can tackle this particular problem, argues economist Wei, it will bring about an absolute power over food safety and with it corruption and, ultimately, a failure of accountability. Similarly opposing top-down approaches to food safety governance, Wang argues:

In the hierarchical system, the leader is powerful to determine which way is employed to conduct the accountability. In practice, to prevent their subordinates as well as themselves from being punished, the leaders are more likely to ascribe these issues to the deficits in the current accountability system, and then justify the actions of their subordinates. $[A]^{3}$

Next to the distribution of accountability, the content of food safety governance is going through transitions in China as well, such as through a transition from increasingly managing food hygiene to supervising food safety 'from farm to fork'. This puts increasing pressure on supervisory bodies, which is, as risk assessors $\mathrm{Xu}$ and $\mathrm{Xu}$ (2008) argue, is the main reason that different supervisory bodies keep shirking the responsibility with each other yet fail to take ownership of the gaps in the distribution of accountability itself. However, according to policy expert Lai (2013), in the context of crises, when someone must take ownership of an issue, the current multi-sectoral system does manage to allocate accountability efficiently, provided there is (some) central state intervention.

This has led to a series of scholars arguing that the failures of accountability infrastructures are thus to be attributed to the characteristics of those systems themselves. Public policy scholars Liu and Zhang (2010) argue that a lack of accountability culture, as well as a lack of available accountability procedures, is to blame:

When food incidents occur, the leaders pay more attention to shirking responsibility rather than ascertaining the truth. Due to the lack of a sense of accountability, these accounters tend to protect their colleagues from being punished and suppress the activation of accountability procedures. $[B]$

Next to a lack of internal accountability culture and procedure, economist He (2011) and legal scholar Kong (2010) argue that external accountability, a way to hold agencies or officials themselves

3. Translated from Chinese by RY and Metamorphose Vertalingen. The original quotes are listed in the Appendix. 
accountable in an attempt to tackle the incapability of governmental supervision in handling the growing complexities of food safety issues, is largely absent from the current governance system. He (2011) explains this as follows:

Media and the public play a critical role in conducting the external accountability to scrutinize the government behaviour. Nonetheless, the media and citizens are unable to hold the public officials accountable, even though they are allowed to engage in the current accountability system. $[C]$

Complementary to a call for more external accountability, Li and Zhao (2009) and Xu and Xu (2008) highlight the need for improving legal and material structures that allow for and facilitate such external accountability. They specifically call for the establishment of regulations and policies that allow and enable the media, as well as the public at large, to participate in accountability infrastructures, which they currently cannot do:

Updating the accountability system to define the accounter, the accountee to allow the public engagement, and to establish a scientific investigation mechanism and information disclosure system should be done. [D]

The debate on public accountability and its structures and systems, as it takes place between Chinese scholars reveals clear tensions between those pursuing a segmented model and those favouring a centralised model, or, in other words, between a centralised top-down approach and promoting stakeholder participation. Calls for centralisation, as identified by some scholars, argue that a single unified supervision body and strict accountability will facilitate responsibility boundary setting. The opposite argument, promoting decentralisation, revolves around expectations that a segmented model including stakeholder participation would allow for managing issues that result from the complexity of the food safety chain. However, calls for greater centralisation, or, on the other hand, less decentralisation, arise out of desires to resolve concrete issues, cases, or crises rather than being built on conceptual and systemic normative requirements at the level of accountability infrastructures.

\subsection{Contextualised risk communication strategies}

Next to governance structures, public understanding of food safety claims and knowledge are important in regard to the public perception of, and public trust in, food safety. A key element in public accountability is managing issues of transparency, information distribution, disclosure, and communication. These themes are addressed in a significant portion of the Chinese food and food safety governance literature we analysed. 
Governing food safety requires communicating with the public in some form. Models and systems of public accountability prescribe exactly what, when, and by whom such communication takes place as well as the exact role it plays in decision-making. Any lack of such communication, especially in the context of imminent crises, directly contributes to some form of public distrust in food safety and food safety governance.

Economic policy experts Wang (2012) and Gu and An (2012) argue that the organisation of communication flows and disclosure strategies is the most essential part of constructing food safety. Based on the notion that the market alone could not be trusted with developing the disclosure of risk information and communication effectively, they argue that the government should take this responsibility upon itself. According to agricultural policy expert Zhang (2009), decentralised multi-sector governance creates asymmetries between information providers (state actors) and information recipients (other stakeholders beyond government) due to vulnerabilities in the system, such as difficulties in defining what to disclose, poor timing, and deficits in coordination and standardisation. Legal expert Kong (2010) argues that these asymmetries need to be overcome by the creation of a single unified information release mechanism. The 2009 food safety law tried to establish such a mechanism, in the process highlighting how the centralised coordination of information management is to be complemented with decentralised coordination. Kong (2010) explains

In practice, the local state should promptly disseminate the information related to food safety regulation online. Meanwhile, the national state should unitarily disclose the information about pre-warning of food safety issue, the process of risk assessment and investigation results when food crises happen. [E]

However, journalist Yuan (2013) argues that this approach fragments information management and thereby brings about new problems. Yuan argues that, while uniform information release may help eliminate some of the information asymmetries created as a result of multi-sectoral governance, such as unclear classification criteria for food safety information, it does nothing to alleviate power-vacuums, gaps in accountability infrastructures, and inconsistent top-down information reporting inside supervisory bodies. In response, public policy experts Wang (2011), Nie and Yan (2009), and Guo et al. (2013) call for an information sharing and coordinating agency built by local governments rather than a unified reporting mechanism. Zhu et al. (2013) imagine this to look as follows:

A coordination system should be established among multi-level regulatory bodies to share Information regard food safety, aiming to get rid of power vacuum and-overlaps. [F] 
In disagreement with Yuan (2013), Zhu et al. (2013), Nie and Yan (2009), and Guo et al. (2013), economists Zhang, et al. (2014) argue that the government should not be the (sole) source of food safety. They also reject the assumption by Nie and Yan (2009) and Guo et al. (2013) that the market is structurally unable to play a role in the information disclosure of food safety Casting the government back into a supervisory role, they argue that private enterprises should take responsibility with respect to food safety information disclosure, thus tackling the information asymmetry issues in information discourse. They, together with Wei (2013) and Liu and Zhang (2015), suggest the creation of an information traceability 'from farm to fork' system across the food industry:

An information traceability mechanism entails a unitary information disclosure system established by the states, in which all the stakeholders in food industry could input information. It will favour the social supervision on the food safety and unload the state's burden. [G]

Tackling the information asymmetry that flows from the multi-sectoral governance system would require, as the authors above argue, a key role for food companies to communicate risk and disclose the relevant information, a role for the government to assess and summarise these information, and the media and public to judge and comment upon both. Such information traceability systems are, however, difficult to implement (Yang, 2012). Legal scholar Qi (2011) argues that China's traditional farming model creates complexity with regard to the diversity of foods products, the ways in which production is organised, and, above all else, how information flows can be made traceable through this system:

Due to the complicity of food production chain in China, such as the wider geographical distribution and scatter model of food production, it has increased the risks in the food chain. $[H]$

To reduce the complexity of food production, Zhang and Sun (2008) and Wan and Mao (2008) proposed moving away from scattered individual household producers to a more cooperative model. Agricultural policy experts Han and Liu (2014) attached the label 'cooperation and company' to this idea: the collectivisation of households in a cooperation supplemented with technical guidance and expertise on food production from companies. Despite the success of this cooperative model, Hao et al. (2015) and Fan et al. (2012) worry that rural cooperation is still not sufficiently organised, especially when compared to other food production organisations of a similar size. For instance, sociologists Hao et al. (2015) empirically demonstrated that medium-sized or small-sized primary food production organisations are more likely to improve productivity but also reduce risk when compared to rural cooperations. Collecting information and disclosing it coherently is more difficult within a cooperation. Agricultural experts Fan et al. (2012) argue that information traceability would 
require compulsory information disclosure that helps supervision bodies to evaluate the degree of the current risk in food safety. This compulsory information should, at the very least, include:

Product name, specifications, net weight, production date, list of ingredients, producer's name, address and contact information and expiration date. [I]

The information should also include place of origin and authoritative certification to earn consumer trust and build reputation. According to Liu and Ge (2012), food labelling regulations complement traceable information and help supervisory bodies, as well as the public, to assess the safety and quality of the foods which they purchase and consume.

However, lawyer $\mathrm{Wu}$ (2013) diagnoses several weaknesses in the information traceability system, including a lack of incentives or mechanism to hold transgressors accountable. Zhang et al. (2014) even argue that current information disclosure and communication practices make food safety a game of chance and that only if the costs of information disclosure are lowered, food companies will actively take responsibility for communicating any aspects of safety. Without incentives to disclose information, or the penalisation of those who refuse to do so, legal expert Wang (2012) argues, food safety governance will remain inefficient. $\mathrm{Wu}$ (2013) suggests that some market logic may be beneficial here, if consumers actively assessed the information disclosed by companies and translated it into an informal food safety reputation score and ensuing sales that result from this practice:

In general, the consumers prefer to purchase food from the enterprise with a good reputation. Once these companies provide unsafe food, then the consumers will not trust them do not purchase the food from them anymore, which will cause economic loss to the company. To earn more profit, the companies have to provide high-quality product and establish their reputation. [J]

Consumer trust is assumed to be reflected, to some extent, in buying behaviour. This allows businesses to compete in terms. of communication, information disclosure, and perceptions of transparency. Thus, as $\mathrm{Wu}$ (2012) and Lai (2013) expect, the establishment of a structure creating information-dissemination-feedback mechanisms would allow business to behave responsibly, promoting their investment in food safety reputation. However, public policy expert Bai (2013) points out a few deficiencies in such reputation mechanisms. For instance, online distributors and retailers may dodge supervision or a regulation system, and many are likely to build reputation outside of this system.

Many online stores are not being supervised by the state. They try to establish the reputation through giving gift and vouchers to earn the positive comments from consumers. [K] 
In these debates between Chinese scholars, three perspectives on risk information management can be distinguished, which further highlights possible accountability infrastructures. Several authors propose repairing information asymmetry through strengthening nationwide governmental supervision, including a unified information release mechanism. In contrast, others argue for an information system to trace 'from farm to table' risks, jointly created and maintained by both the state and market to overcome any weaknesses in local state governance, including protectionism, bureaucracy, and poor supervision capacity. A third proposal highlights a structure resembling a free market, in which company reputations drive market success, while allowing for the participation of other non-state actors, such as the media and public.

\subsection{Experts in risk assessment}

Any form of governance with respect to food safety, as well as any accountability infrastructure surrounding risk communication and information disclosure, heavily relies upon the expert assessment of claims and evidence. How does the expert assessment of claims and evidence play a role in the risk regulation of food safety in China? Liu and Ge (2012) argue that a shift from food safety crisis response to risk regulation is crucial in the construction of food safety. In this process of risk regulation, risk assessment described the moment in time at which scientific expertise is foregrounded in governance. According to legal scholar Yang (2012), food safety regulations explicitly state that risk assessments are to be treated as the scientific basis for the formulation of standards and thus inform supervisory and oversight practices. As a consequence, food science experts play a large role when it comes to food safety and, ultimately, public trust in food safety (Yang, 2012).

According to Wang (2012) and Gong (2013), the essence of a scientific risk assessment is to reduce the uncertainties associated with a risk, thereby limiting any undesired side effects. Lawyer Qi (2011) argues that such adverse effects originate either in the (objective) damage food safety issues can inflict upon society or (subjective) public distrust in the state supervision of all food-related matters. In 2009, a risk assessment model was established in which an expert committee was tasked with documenting both objective and subjective food safety risks, with the explicit aim to restore public trust in state authorities (Chen, 2011; Wang and Mao, 2008). The affiliated experts were, however, for the most part, also affiliated with governmental agencies. Wang and Mao (2008) stated:

Many experts are salaried by the public institutions in China and therefore become spokesperson of state to legitimatize the policy made by states, and try to mitigate public distrust in the state. [L] 
Such a top-down approach to risk assessment places scientific experts in a very powerful position. They can legitimate policies based on whether or not they argue their having a scientific basis. However, this strategy for creating public trust has been questioned by Chinese scholars. Qi (2011), Peng (2009), and Qi and Tang (2014) questioned the independence of experts in light of their political affiliations and interests and argue that this will result in a loss of public credibility given to their claims. These scholars discuss how to ensure expert committees stay independent from the government and do not speak truth to power. Social economist Yang (2012), drawing from experiences in the EU and US, proposes devising a legal framework to ensure expert independence:

An expert committee should be established to be independent from the state and company. Meanwhile, the relevant regulation and moral value should be reshaped to ensure experts' behaviour, and a special financial budget should be arranged to ensure the fairness of expert committee. [M]

However, Peng $(2009,2010)$ questions whether the expert's state-affiliations are in fact the origin of public distrust. Peng (2010) and Qi and Tang (2014) highlight the many interpersonal differences between experts and the public, as well as between experts themselves, when it comes to food safety risk perception. Experts are not a homogeneous group. Peng (2010) explains that:

Public experience and scientific knowledge can be understood as the different ways to perceive the risks in society, which are both effected by the culture, personal cognition. The rational and expert knowledge is not necessary objective, and lay people should not be conceptualized as ignorant. [N]

Moreover, according to Peng (2009), experts are not the only source of credibility. Peng and He (2011), Qi and J. Tang (2014), and Tang (2009) propose an alternative way for building public credibility, or trust, namely through stakeholder participation in risk assessment. This would allow policy-makers, scientific experts, businesses, Non-Government Organisations (NGOs), and the public to take different means to assess risks and subsequently seek consensus. Peng argues:

The government should encourage the public to involve in the risk assessment activities and monitor the risks in food chain. Meanwhile, the regulations and laws could be established to keep the openness of risk assessment. [O]

Qi (2011) disagrees with both Yang in terms of the pursuit of the independent expert and Peng in terms of his plea for the widening of what can be considered legitimate expertise. Qi argues that, especially in the case of high degrees of scientific uncertainty, conflicting value judgements can arise among both experts and the public. Practically, it is impossible to locate independent experts given that, through membership in an expert committee, they effectively become government officials (Qi 
2011). The expert committee and its expert members are thus intricately tied to government by default. Rather than pursuing public participation, as Peng argued, Guo (2016) proposes the participation of a wider set of relevant stakeholders in risk-assessment in an attempt to curtail its top-down character:

During the risk assessment, stakeholders can invite different experts to represent their value and benefits. In doing so, they could discuss, debate, bargain and reach a compromise during the risk assessment. [P]

Alternative models of organising risk assessment in China can be recognised in Chinese academic literature, but they all remain controversial. Some argue that food risk and safety assessments made by state-affiliated experts produce scientific, effective, efficient, and credible results as well as public trust. In stark contrast, others criticise this strategy as creating even more distrust. The public perception of expert credibility in China is, as Zhang (2005) has argued, inversely correlated with state proximity to risk assessment of food safety. That does not mean that extended stakeholder participation is an easy or obvious solution. Public participation, as well as the participation of other stakeholders, in the negotiation of which evidences to take into consideration for decision-making is, after all, difficult everywhere in the light of the dominant role the scientific expertise plays in the Chinese food safety governance (see e.g. Moes et al., 2017).

\section{Discussion}

In this paper, we analysed how Chinese scholars have discussed the governance of food safety in China and how, in the process, public accountability for food safety has become publicly articulated. The analysis of these scholarly debates provided in this paper shows how different assemblages of politics and science are proposed along the way of food safety governance. Several scholars argue in favour of strengthening centralised power, emphasising that a unified supervisory model and a top-down approach to the governance of food safety will help alleviate challenges in establishing boundaries between responsibilities, information transparency, and governments dodging blame. Others propose de-centralisation and argue that decentralised power was and will be able to facilitate food safety supervision and accountability as the food chain becomes increasingly complex. They argue that decentralisation supplemented with (some degree of) stakeholder participation would help overcome deficits associated with top-down governance. These deficits include the risks that accompany absolute power, corruption, and overly close ties between experts and the state. Involving stakeholders, they argue, would promote transparency, discussion, and a negotiation between the diverse ways to perceive risks, thus slowly creating the required support and participation needed to work towards a consensus (see Table 3 ). 
Table 3 Overview of arguments in Chinese scholarship

\begin{tabular}{|c|c|c|c|}
\hline $\begin{array}{l}\text { Accountability } \\
\text { infrastructures } \\
\text { (Section } 1 \text { ) }\end{array}$ & $\begin{array}{l}\text { A centralized infrastructure is } \\
\text { not only a solution for } \\
\text { tackling the unclear } \\
\text { distribution of responsibility } \\
\text { formed by the segmented } \\
\text { model, but it presents the } \\
\text { problem of absolute power } \\
\text { and the failure of internal } \\
\text { accountability in the } \\
\text { construction of public } \\
\text { accountability }\end{array}$ & $\begin{array}{l}\text { A decentralized } \\
\text { infrastructure } \\
\text { among } \\
\text { multi-level regulatory } \\
\text { bodies is the solution to } \\
\text { improving the states' } \\
\text { capacity to deal with the } \\
\text { complexity of the food } \\
\text { chain, yet it presents a } \\
\text { problem because it causes } \\
\text { power vacuums and } \\
\text { overlaps. }\end{array}$ & $\begin{array}{l}\text { A decentralized } \\
\text { infrastructure between } \\
\text { the state and society is } \\
\text { the solution to unloading } \\
\text { the burden of the state } \\
\text { and constructing } \\
\text { inclusive governance, } \\
\text { but it also triggers issues } \\
\text { in the collaboration } \\
\text { between experts and the } \\
\text { public. }\end{array}$ \\
\hline $\begin{array}{l}\text { Risk } \\
\text { communication } \\
\& \text { transparency } \\
\text { (Section 2) }\end{array}$ & $\begin{array}{l}\text { More government control } \\
\text { over risk communication and } \\
\text { to compensate for the failure } \\
\text { of commercial parties will } \\
\text { favour information } \\
\text { transparency of food safety }\end{array}$ & $\begin{array}{l}\text { More market control over } \\
\text { information disclosure, as } \\
\text { the state cannot have all } \\
\text { power when it comes to } \\
\text { information disclosure }\end{array}$ & $\begin{array}{l}\text { Balancing state and } \\
\text { market control should } \\
\text { include the oversight } \\
\text { roles for the media and } \\
\text { the public }\end{array}$ \\
\hline $\begin{array}{ll}\text { Experts \& risk } \\
\text { assessment } & \\
(\text { Section 3) } & \end{array}$ & Experts working for the state & $\begin{array}{l}\text { Independent } \\
\text { committee }\end{array}$ & $\begin{array}{l}\text { Stakeholder or public } \\
\text { participation }\end{array}$ \\
\hline
\end{tabular}

Interestingly, our analysis revealed that the disciplinary backgrounds of scholars influence how they frame the accountability for food safety. It appears that public policy experts and legal experts are more likely to stress the recentralized model and update the regulations and laws aimed at strengthening the regulation and accountability of food safety as well as improving institutional efficiency. Mostly sociologists conceptualized the accountability of food safety as a social issue, and focus on a decentralized way to allow for public engagement in the governance of food safety. Economists and enterprisers have mentioned an information traceability system and emphasize the role of the market in food safety regulation. Moreover, we solely focused on scholarly arguments from four Chinese databases and excluded other stakeholders' opinions. To obtain additional insights into the accountability system of food safety in China, future studies should glean data from the narratives of diverse stakeholders (e.g. citizens, public officials, journalists, experts, and enterprises) related to the construction of an accountability infrastructure for food safety in China.

China's food safety governance is discussed in international academia as well. Some scholars stressed constructing a stringent food safety control system after China Melamine Milk Scandal in 2008 to contain the fragmentation of regulatory authorities and manage regulatory confusion, whereas more studies pointed out that a strict food safety regulation system did not yield an effective food safety regulatory performance, instead, it increased the regulatory cost and created a negative incentive for diverse stakeholder participation to co-govern food safety (Pei et al., 2011). Zhang et al. 
(2015) argued that the lack of external participation has delayed the growth of food safety regulatory capacity in China while the construction of a co-governance system would have helped assure food safety in China. In Chinese academia some scholars have pointed to the importance of stakeholder participation, but in international studies this is stressed even more. Many studies that stressed the positive role of diverse stakeholder engagement in food safety governance were published in journals such as Food Control, Food Policy and Regulation and Governance. Drawing from a few of them, for instance, Liu et al. (2013) proposed professional risk assessment in the food supply chain, independent from the state Xue and Zhang (2013) and Ma and Liu (2019) recommend reciprocal risk communication between the state and citizens to mitigate the high risk perception of citizen caused by frequent food safety incidents. Ma et al. (2018) point to the importance of cooperation of players in food supply chain to improve their capacity to assure food safety. Zhu et al. (2019) and Kang (2019) noted the initiatives of societal actors in constructing a traceability system to enhance information transparency. The analysis in this review indicated that Chinese scholars were more pessimistic about co-governance and argued that co-governance was still far from mature in China. They pointed to the fact that enterprises sought to maximize benefits and were reluctant to assume social responsibilities. They would, accordingly not maintain information transparency when the cost of information disclosure was high, and when laypeople were marginalised in risk assessment dominated by experts. As such, Chinese scholarship documented in this study emphasized a recentralized model to forge a strict regulation and accountability system aiming to control food safety effectively in China, more than they did stakeholder participation.

How do these findings relate to the theoretical discussions on governance and public accountability from which we initiated this analysis? Perhaps remarkably, discussions about government and governance in western scholarship do not at first appear to be that different from Chinese discussions. However, in western public accountability scholarship, the intrinsic value of democracy appears to be more important than technical institutional efficiency; this is not a surprise, as the value of democracy is a shared, driving force in accountability discussions (Bovens et al., 2014). Public accountability is about democracy, and, putting it simply, the main issue of public accountability is whether top-down or bottom-up approaches are contributing or hampering democratic and inclusive forms of decision-making. As such, institutional efficiency in the manner of multi-level accountability is discussed within the context of democracy.

Our review suggests a different bandwidth for balancing the modes of participation and institutional efficiency in Chinese scholarly debates. This is also not very surprising, not only because of the political context of China, in which the state is the central political power determining the meaning of democracy, but also because our analysis included a number of concrete food scandals producing severe consequences, scandals that tended to call for institutional control rather than for 
democratising governance. In this respect, the debates we analysed illustrate a rich array of options and arguments related to public accountability in China. We did not discuss the relationship between scholarly debates on public accountability for food safety and recent changes in the actual practices of governance. However, narratives of centralisation and decentralisation as well as the mobilisation of power and shared (democratic) values are reflected in contemporary reforms of the public accountability structure in China (Gradstein, 2017).

STS scholars attend to the ways food safety governance is legitimized by scientific evidence, technological procedures and political action. Jasanoff (2007), for instance, recognises that scientific and technological practices matter in the making of democracy, including the ways in which one can organise public engagement and participation, as well as access to food safety information. In 2015, a multi-level governance system was established that recognised and, to some degree, facilitated the public's ability to participate in supervision and accountability in order to hold the government and businesses accountable (Ma, 2015). Simultaneously, in 2016, third-party testing agencies were allowed to participate in the risk assessment infrastructure, with the aim of solidifying top-down governance (Shao and Hu, 2016). Highlighting the hierarchical knowledge order upon which science is highly dependent and integrated with political institutions, it was by no means a surprise that some form of centralisation can be found, even at the heart of decentralisation and the development of participatory governance as well as the accountability structures in the big government context of China (Kostka and Nahm, 2017). Accountability infrastructures were intensified with the purpose of tackling bureaucracy, weak incentives, and buck-passing in local states in 2015 (Ma, 2015). Three years later, in 2018, the Chinese central state further reinforced centralisation through combining the Industry and Commerce Administration, the Food and Drug Administration, and the Quality and Technology Administration into the Bureau of Market Regulation. Disclosed arguments in the Chinese public forum included overcoming institutional fragmentation and weak incentives as well as improving policy outcomes when it comes to the heterogeneity of local governments with respect to interests, motivation, efforts, capacity impeding the good outcomes (Wang and $\mathrm{Su}, 2018$ ).

Food safety governance infrastructures embody scientific, societal, and political elements. The Chinese scholarly debate on accountability in food safety governance, as well as recent developments in food safety governance, display coexisting centralisation and decentralisation efforts. However, highly centralised and decentralised infrastructures represent different relationships between different cultural domains. Absolute centralisation subjects social and scientific domains to the political, whereas decentralisation, especially when accompanied by participatory turns in the public accountability of food safety, allows for a more balanced conversation between all three, allowing for, at the very least, some reciprocity (Peng, 2009) 
Nowotny et al. (2003) and Gibbons (1999) have, among others, argued that science has a social contract with society that prescribes a dynamic process in which the authority of science needs to be continuously legitimated. This is facilitated by the existence of forums in which scientific knowledge engages with the public, and the public responds to science. Accordingly, the public can participate in the production of socially robust knowledge (Penders, et al., 2009). In the Chinese situation described above, the lasting pivotal role the Chinese central state suggests the operationalisation of a different social contract between science and society, in some ways resembling that of the West, in other ways diverging radically. While on the one hand the construction of socially relevant knowledge and technology is exchanged for political support, on the other hand, the articulation of what constitutes relevant knowledge and technology is a process organised more centrally and less inclusively. The latter remains, despite of the reforms mentioned above that allow increasing public engagement in the process of knowledge production. Food safety governance demonstrates how science-society relationships in China are a continuous work-in-progress-just like they are elsewhere.

Kuipers and 'T Hart (2014) emphasized that the public calls for accountability in the wake of crises. In line with this notion, Chinese scholars argue that, when confronted with crises, Chinese governments have responded to such pressure by conducting investigations, allocating blame and implementing sanctions. Drawing from the Oxford Handbook of Public Accountability, three additional fora of accountability in the West can be discerned: technical accountability operated by professional agencies, such as the Environmental Protection Agency and Medical Licensing Authority, judicial investigation launched by courts to establish causality and ascertain responsibility, and the political accountability initiated by opposing forces to hold executive power accountable. These four streams of inquiry and accountability continuously intersect. However, in the Chinese context, as our review suggests, a somewhat different scenario plays out. While Chinese scholarship stresses professional inquiry and accountability, as well as creating a venue for stakeholder participation, these strategies of scrutiny continue to operate within a top-down system. Differing from the notion that western public accountability scholarship contributes to democracy, public accountability in China focuses more on institutional efficiency and institutional trust.

Jasanoff (2003) distinguishes two routes in which science, technology, and society coproduce each other, whether in the context of infant formula safety or elsewhere. In her work, she distinguishes two strategies for scientific and technical expertise pursuing such coproduction. scientific expertise can act as 'technologies of humility' and 'technologies of hubris'. Clearly manifested in the case presented here are the 'technologies of hubris', imposing such change in a top-down manner with little contextual sensitivities. This review of Chinese scholarly literature thus raises the question as to whether the study of accountability in Chinese governance contexts is in need 
of manifestations of Jasanoff's second route through developing its own, locally embedded and relevant Chinese technologies of humility. These would accommodate specific governance infrastructures, in which scientific knowledge is always partial, power is never absolute, and ambiguity, indeterminacy, and complexity are woven into the fabric of publicly accountable decision-making regarding food safety in China.

\section{Conclusion}

This analysis highlights the scholarly debates on the centralization and recentralization related to public accountability for food safety in China. The pursuit of recentralization contributes to the construction of a stringent top-down accountability, while that of decentralization, allowing for diverse stakeholder engagement, favours unloading the burden of states and constructing an inclusive governance system. These diverging perspectives provide opportunities to learn how the governance of food safety is organized and practiced as well as how the relevant knowledge about the public accountability is produced in the authoritative context of China. The analysis indicates that top-down regulations aim to promote technical institutional efficiency to assure food safety in China, but that silencing divergent voices and local knowledges undermines the accountability infrastructure as well as the quality of food safety governance practice.

\section{References}

Adams, V., 2016. Metrics: What counts in global health. Duke University Press.

Alemanno, A., 2015. The regulatory cooperation chapter of the transatlantic trade and investment partnership: institutional structures and democratic consequences. Journal of International Economic Law, 18(3), pp.625-640.

Bai, J., 2013. Research on Food Quality and Safety Traceability Information Management System. Information Science, 7 (3), pp. 59-63.

Balla, S.J. and Gormley Jr, W.T., 2017. Bureaucracy and democracy: Accountability and performance. CQ Press.

Bovens, M., Goodin, R.E. and Schillemans, T. eds., 2014. The Oxford handbook public accountability. Oxford University Press.

Bovens, M. and Schillemans, T., 2014. Meaningful accountability. In: Bovens, M., Goodin, R.E. and Schillemans, T. eds. The Oxford Handbook of Public Accountability (pp. 673-682). Oxford University Press, pp. 673-682.

Busuioc, M. and Rimkute, D., 2019. The promise of bureaucratic reputation approaches for the EU regulatory state. Journal of European Public Policy, pp.1-14.

Chen, R., 2011. The Damaged Credibility of Administration, the Media, the Expert, the People "Never Believe It". People's Daily, September 8. http://news.cntv.cn/20110908/105731.shtml.

Chinese Ministry Of Health., 2015. China Health Statistics Yearbook in 2005. Beijing: Beijing Union Medical University Press.

Deng, C., 2010. Research on the Food Supervision Model in China. PhD diss., Sun Yat-Sen University.

Fan, C., 2008. Experience from Foreign Food Safety Supervision Models__Establishing the Infromation Disclosure System 'from Farm to Table. Journal of China National School of Administration, 3(8), pp. 96-98.

Fan, C., Jia, J. and Li, H., 2012. Public Perception of Risk and Coping Behavior in the X Food Safety Incident - a Case Study of the Milk Powder Incident. Management Review, 1 (2), pp. 163-168.

Finders, M., 2014. The Future of Relevance of Accountability Studies. In: Bovens, M., Goodin, R.E. and Schillemans, T. eds. The Oxford Handbook of Public Accountability. Oxford University Press, pp. 661-672

Gibbons, M., 1999. Science's New Social Contract with Society. Nature, 402, pp. C81-C84. 
Gong, Y., 2013. Research on the Countermeasures of China's Food Safety Risk Source Management Based on Analytic Hierarchy Process. Food Technology, 6 (3), pp. 330-333.

Gradstein, M., 2017. Government decentralization as a commitment in non-democracies. Journal of Comparative Economics, 45, pp.110-118.

Gu, C, and An, Y., 2012. Analysis of Game on Food Safety Information Disclosure. Research on Economics and Management, 1(2), pp. 38-45.

Guo, F., 2016. Expert Trust, Crisis and Reshaping. Science Research, 8 (6), pp. 31-36.

Guo, Q., Tan, T. and Wang, T., 2013. Research on Long-Term Mechanism of Food Safety Supervision in Hebei Province_ from the Perspective of Supply Chain Collaboration. Journal of Hebei University of Economics and Business 34, no. 4 (2013), pp. 51-55.

Hai, X., 2004. Decision of State Council About Further Strengthening Food Safety'— - the New Thought Analysis on Food Safety Supervision Model. Fujian Province of Quality and Technology Supervision, 9 (2), pp. 14-15.

Han, Z. and Liu,Q., 2014. Contract Stability Analysis of "Company + Farmer" Farming Model under the View of Social Capital and Governance. Rural Economy, 8 (4), pp.41-46.

Hao, L., Li, D. and Liu., 2015. Analysis of the Efficiency of Different Breeding Models of Chinese Dairy Cattle Industry. China Rural Observation, 3 (3), pp. 64-73.

He, Y., 2011. Problems and Countermeasures of the Administrative Accountability System for Food Management in China. Journal of Changchun municipal Party school, 5 (1), pp. 37-39.

Jasanoff, S., 2003. Technologies of Humility: Citizen Participation in Governing Sience. Minerva 44, pp. 223-244.

Jasanoff, S., 2007. Technologies of Humility. Nature, 450, pp. 33.

Jiang, Q., \& Zhu, Y., 2013. Confronting the crisis of food safety and revitalizing companies' social responsibility in the People's Republic of China. Asia Pacific Business Review, 19, pp. 600-616.

Kang, Y., 2019. Food safety governance in China: Change and continuity." Food Control 106, pp. 106-115.

Klijn, E.H. and Koppenjan, J. F. M. S., 2014. Accountable networks." In: Bovens, M., Goodin, R.E. and Schillemans, T. eds. The Oxford handbook of public accountability. Oxford University Press, 2014, pp.242-256.

Kong, F., 2010. Research on China's Food Safety Information Disclosure System. Journal of South China Normal University (Social Science Edition), 3 (4), pp. 5-11.

Kostka, Genia. and Nahm, J., 2017. Central-Local Relations: Recentralisation and Environmental Governance in China. The China Quarterly, 231, pp. 567-82.

Kuipers, S., and Hart, P., 2014. "Accounting for crises." In: Bovens, M., Goodin, R.E. and Schillemans, T. eds. Oxford Handbook of Public Accountability. Oxford University Press. pp.589-602.

Lai, S., 2013. Accountability, Path Dependence and Disclosure: Studies on Local Government Behavior Based on 97 Cases of Public Crisis. Journal of Public Administration Research and Theory, 10 (2), pp. 18-27.

Lam, H. M., Remais, J., Fung, M. C., Xu, L. \& Sun, S. S. M., 2013. Food supply and food safety issues in China. The Lancet, 381, pp. 2044-2053.

Li, H. and Zhao, T., 2009. Change and Design in China's Food Safety Regulation System. Research on Financial and Economic Issues, 10 (9), pp. 16-23.

Liu, D. and Ge, Y., 2012. Gb7718-2011 "National Food Safety Standards of Pre-Packaged Food Labels General. Food Industrial Technology, 16 (2), pp. 28-30.

Liu, P., 2010. China Food Safety Supervision - Empirical Research on Institutional Change and Performance Evaluation. Journal of Public Administration Research and Theory, 7 (1), pp. 63-78.

Liu, P. and Zhang., 2015. Reseach on the Vertical Power Allocation in China's Food Safety Supervision System. Journal of Central China Normal University (social science version), 1 (5), pp. 28-34.

Liu, S., Xie, L., Zhang, W., Xia, C, and Pei, X., 2013. Risk assessment in Chinese food safety. Food control, 30(1), pp. 162-167.

Liu, S., and Zhang., 2010. Analysis of Food Safety Accountability System. PhD diss., Hunan University

Lu, F., and Wu, X., 2014. China food safety hits the "gutter". Food Control, 41, pp.134-138.

Ma, L. and Liu, P., 2019. Missing links between regulatory resources and risk concerns: Evidence from the case of food safety in China." Regulation \& Governance 13(1), pp. 35-50.

Ma, W., Alan R., Peng, Y. and Ratna, N., 2018. Agricultural cooperative membership and technical efficiency of apple farmers in China: An analysis accounting for selectivity bias." Food policy, 81, pp. 122-132.

Ma, Y., 2007. Research of Governmental Supervisory Bodies. Peking University Press, pp. 6. 
Ma, Y., 2015. Breaking through the Dilemma of Multi-Level Department: Analysis of the Coordination between China's Food Safety Supervision Department. Tsinghua Law Journal, 3 (5), pp. 35-36.

Moes, F., Houwaart, E., Delnoij, D. and Horstman, K., 2017. Contested evidence. A Dutch reimbursement decision taken to court. Health, Economy, Policy and Law, 12(3), pp. 325-344.

Moffitt, S. L., 2010. Promoting agency reputation through public advice: Advisory committee use in the FDA. The Journal of Politics, 72(3), pp. 880-893.

Nie, Y. and Yan., 2009. Inter-Departmental Cooperation from the Perspective of Relational Contracts: Taking Food Safety Regulation as an Example. Social Science, 11 (9), pp. 13-20.

Nowotny, H., Scott, P. and Gibbons, M., 2003. Mode 2' Revisited: The New Production of Knowledge. 'Mode 2' Revisited. The New Production of Knowledge 41,(3), pp. 79-94.

Pei, X., Tandon, A., Alldrick, A., Giorgi, L., Huang, W. and Yang, R., 2011. The China melamine milk scandal and its implications for food safety regulation. Food policy, 36(3), pp.412-420.

Papadopoulos Y., 2014. Accountability and Multi-Level Governance. In: Bovens, M., Goodin, R.E. and Schillemans, T. eds. Oxford Handbook of Public Accountability. Oxford University Press, pp. 273-285.

Penders, B., 2018. Why public dismissal of nutrition science makes sense. British Food Journal,.120, pp. 1953-1964.

Penders, B., Vos, R. and Horstman, K., 2009. Sensitization: reciprocity and reflection in scientific practice. EMBo reports, $10(3)$, pp.205-208.

Peng, F., 2009. Expert Governance Model in the Reconstruction of the Food Safety Risk Assessment. Journal of Gansu Political Science and Law Institute, 6 (9), pp. 6-10.

Peng, F., 2010. Risk and Law: How Is the Allocation of Food Safety Responsibility Possible. Journal of Gansu Political Science and Law Institute, 1 (2), pp. 43-48.

Qi, H. and Tang, J., 2014. Analysis of the 'Duality of Expert Rationality 'in Food Safety Risk Assessment . Journal of Kunming University of Science and Technology, 8 (2), pp. 12-17.

Qi, J., 2011. Speaking Power to Truth: Application of Information Tools in Food Safety Risk Regulation. Jianghuai Forum, 5 (1), pp. 115-24.

Shao, M. and Hu, Z., 2016. How to Keep Food Safety Governance Effectively: State or Market? Finance Economics, 3(6), pp. 103-112.

Tang, W., 2009. Public Participation in the Food Safety Risk Assessment System. Theory Monthly Magazine, 10 (9), pp. $12-15$.

Wan, J., 2008. Vertical Integration, Relationship Governance and Contract Performance -- an Example of Wen's Model of Agricultural Industrialization. Managment World, 12, pp. 12-15.

Wang, G., 2011. Food Safety Information Determines the Success or Failure of Regulation. China reform 8 (1), pp. 15-19.

Wang, K., 2012. Review of Food Safety Information Infrastructure. Economics Dynamic, 8 (2), pp. 8-15.

Wang, K. and B Li, B., 2007. Food Safety Issues and Their Regulation Discussion. Modern Economy Exporation, 4 (7), pp. $44-47$.

Wang, K. and Su X., 2018. The Evolution Track and Characteristics of China's Food Safety Policy. Innovation Reform, 2 (3), pp.22-26.

Wang, L., He, J. and Zhu, M., 2009. Analysis of China's Dairy Food Safety Supervision System under the Vision of Collaborative Government. China Administrative governance, 10 (9), pp. 21-24.

Wang, X., 2012. China's Food Safety Legal System in the Risk Management System. Jinnan Journal (Philosophy and Social Sciences), 2 (2), pp. 22-26.

Wang, Z., Mao, Y. and Gale, F., 2008. Chinese consumer demand for food safety attributes in milk products. Food policy, 33(1), pp.27-36.

Wei, C., 2013. Exporing the Improvement of China's Food Safety Supervision System. Journal of Jiangxi University of Finance and Economics 2 (3), pp. 189-190.

Weingart, P., 1999. Scientific expertise and political accountability: paradoxes of science in politics. Science and public policy, 26(3), pp.151-161.

Wu, Y., 2012. Information Infrastructure, Reputation Mechanism and Law Enforcement Optimization-a New Perspective of Food Safety Governance. Chinese Social Sciences, 6 (2), pp. 115-33.

Wu, Y., 2013. Study on the Construction of Food Safety Credit File System. Study on the Law and Business, 4 (3),pp. $11-20$.

Xu, G., Wei, Y, and Li, T., 2014. Reform of China's Public Budget Governance: Transparency, Accountability, Public Participation, Response. Journal of Renmin University of China, 28 (6), pp.124-131. 
Xu, H. and Xu.Y., 2008. Evaluation of Food Safety. Beijing: China Forestry Press.

Xue, J, and Zhang, W., 2013. Understanding China's food safety problem: An analysis of 2387 incidents of acute foodborne illness. Food Control, 30(1), pp. 311-317.

Yan, Y., 2012. Food safety and social risk in contemporary China. The Journal of Asian Studies 71, pp. 705-729.

Yang, X., 2012. Comparison of the Independent Principles of Risk Assessment of Food Safety in Europe and China. Administrative Law Research, 4 (2), pp. 122-28.

Yuan, D., 2014. The Economic Market Was Born, Where Should the Food and Drug Supervision System Go? Southern Weekend, 29 August. http://news.ifeng.com/a/20140831/41803881_0.shtml

Zhang, X., 2005. Chinese consumers' concerns about food safety: based on case of Tianjin. Journal of International Food \& Agribusiness Marketing, 17 (25), pp. 57-69.

Zhang, C., 2009. Reconstruction of Food Quality and Safety Supervision System under Market Failure and Government Failure__ Taking "Sanlu Milk Powder Incident" as an Example. Gansu Social Science, 2 (9), pp. 242-45.

Zhang, D. and Han, M., 2018. Power and Responsibility, Procedure, Transparency, Monitoring, Accountability_Restriction and Supervision Mechanism of Internal Power Operation in Universities. China Higher Education Research, 3(1), pp. 28-34.

Zhang, F., Fan, F. and Ren, B., 2014. Study on Vertical Integration of Firm Boundaries Based on Transaction Cost Theory. Zhengzhou Academy for Economical Administration press, 1 (4), pp. 12-15.

Zhang, G., 2007. Public Administration. Peking University Press.

Zhang, J.Y., 2015. The 'credibility paradox'in China's science communication: Views from scientific practitioners. Public Understanding of Science, 24(8), pp.913-927.

Zhang, M., Hui, Q., Xu, W., Pu, M. Z., Yu, Z. J., \& Zheng, F. T., 2015. The third-party regulation on food safety in China: A review. Journal of Integrative Agriculture 12 (11), pp. 2176-2188.

Zhang, X. and Sun, C., 2008. China's Food Safety Supervision System: Situtation, Problems and Solutions--Based on the Perspective of the Principal of Food Safety Supervision. Economic System Revolution, 1 (8), pp. 45-48.

Zhu, A., Chang, W. and Liu, L., 2003. "Discussion on Building a Food Safety Information Sharing Platform." Naval Medical Journal, 34 (5), pp. 343-45.

Zhu, X., Huang, L. Y., and Manning, L., 2019. The role of media reporting in food safety governance in China: A dairy case study. Food control 96, pp. 165-179.

\section{Appendix 1:}

Table 1 search word overview linked to database used

\begin{tabular}{ll}
\hline Key themes & Key terms \\
\hline Supervision system & $\begin{array}{l}\text { 'Food safety' [title] and 'multi-sector supervision' or 'centralised department' or } \\
\text { 'supervision system transition' or 'supervision problems' or 'food safety incidents' }\end{array}$ \\
Accountability System & $\begin{array}{l}\text { 'Food safety' [title] and 'supervision model' or 'external/internal accountability' or } \\
\text { 'accountability procedure' or 'bureaucratism' or 'food safety incidents' or 'public/media } \\
\text { participation' } \\
\text { 'Food safety' [title] and 'multi-sector information release' or 'unified information release } \\
\text { mechanism' or 'information sharing/coordination' or 'private enterprise' [subheading] } \\
\text { and 'information traceability system' or 'enterprise reputation' or 'rural household's } \\
\text { breeding model' or 'supervision mechanism' } \\
\text { 'Food safety' [title] and 'expert committee' or 'value-neutral/interest reciprocity' and } \\
\text { 'limited rationality/public rationality' or 'stakeholder participation in risk assessment' }\end{array}$ \\
\hline
\end{tabular}

Table 2 selection criteria for study inclusion and exclusion

\begin{tabular}{ll}
\hline Inclusion & Exclusion \\
\hline
\end{tabular}


1. Scientific/scholarly peer-reviewed articles, conference papers, 1. Articles, newspapers or reports that only

government reports, media reports.

2. Chinese or English language

3. Papers focus on governance of food safety

4. Papers published after 2000 until September, 2017 mentioned food safety in the conclusions and recommendations

2. Papers focusing on technical, toxicological or physiological discussions on food safety

3. Paper focusing on foreign food safety research

\section{Appendix 2: Primary sources}

A. 在官僚体制, 领导有能力帮助下级逃避问责, 问责制度主要关注与官员的错误行为, 但是, 忽视了改善 制度的不合理性和漏洞。导致官官相护，领导轻易的庇护下属逃避惩罚，把责任归处于不合理的制度， 最终导致了问责制度的无效运行。

B. 当安全事故发生时，当权者关注的是以何种理由逃避自身责任而非通过问责理清事故发生的原因。同 时，由于“官官相护”的氛围存在，追责者没有缺乏问责意识，而倾向于保护他们的同时免受责罚，阻止 问责启动。

C. 外部问责, 就是媒体和公众作为问责主体, 监管政府官员的行为。但是文责权力仍掌握在政府手里, 政 府系统内部问责，尽管人们代表大会制度允许公民参与到问责中。

D. 重新设计问责的运行机制, 明确规定谁是问责主体, 谁是被问责者; 扩大问责的渠道确保大众参与;健 全取证制度, 保证问责决定的客观性; 建立信息发布制度和快速反应机制, 保证信息的公开透明

E. 安全信息分为“重要信息”和“日常信息”:前者由卫生部门统一发布, 后者由其他监督部门依据各自职责 公布日常监管的信息。主要信息主要包括国家食品安全总体情况、风险预警信息、重大全事故及调查处 理，日常信息局限于地域内的安全信息。同时规定了，部门之间的通报制度和上下级的信息报告制度。

F.

信息共享机制本质在于建立各部门之间的协调机构, 实现信各部门信息交换。 同时, 明确各监督部门食品安全信息公布的范围和程序; 规定信息通报与报告工作机制的主体、对象、 时效、信息范围和方式, 力图克服权力真空和重叠。

G. 信息安全追溯机制是指由政府建立统一的信息公布平台, 企业承担信息公布职责, 通过登录平台, 输入 强制性公布的信息和其他真实信息, 有利于消费者了解企业的食品生产。而政府承担公布宏观食品安 全信息和核查信息真实性的责任。同时，媒体和大众可对食品安全信息的真实性进行监督。

H. 在过去的几十年里, 中国原材料生产的复杂性, 农户采用散养模式经营, 具有地域分布广, 产品多样, 组织化程度低的特点, 导致了食品安全风险增加

I. 名称、规格、净含量、生产日期 2.成分或者配料表 3.生产者的名称、地址、联系方式 4. 保质期 5.产品标 准代号 6. 储存条件 6.食品添加剂的通用名称 8. 生产许可证编码.

J. 消费者倾向于在那些声誉较好的企业购买食品。一旦企业提供劣质商品, 消费者将不再信任他们, 并且 不在购买他们的商品。这将会企业带来严重的经济损失, 因此, 为了获取更得消费者信任, 他们需提供 优质的商品, 来构建声誉。

K. 许多网上店铺没有被政府监管所覆盖零售商倾向于通过返现、赠送购物券来引导消费者给予好评价, 以构建声誉。 
L. 许多专家受到政府资助, 因此他们作为政府的代言人, 来为政府决策提供合法性, 并试图消除大众对 政府的不信任。

M. 其原则是风险评估和风险管理分离, 专家委员会独立于行政机关和食品生产企业之外.建立相应的规范 和程序确保专家委员会的“自主性’, 公共利益价值来约束专家, 为其安排专门的财政预算。

N. 大众经验和专家知识是理解社会的不同方式, 都受到文化和个人感知的影响。理性的、科学的知识不一 定是客观的, 大众经验未必是无知的。

O. 政府应该动员、引导、支持公众参与当前的风险评估活动, 参与食品风险监管; 另一方面, 立法机构保证 风险评估过程的公开、透明。

P. 在此模式中, 专家虽然依然是食品安全风险评估者和信息提供者, 相关利益者将会参与风险评估, 这就 意味着他们可以邀请自己的专家共同的参与风险评估。当专家得出评估结论时, 他需要对此进行解释, 接受同行审核和公众质疑

\section{Appendix 3: Overview of experts and sources}

\begin{tabular}{|c|c|c|c|c|c|}
\hline $\begin{array}{l}\text { Analysed } \\
\text { documents }\end{array}$ & Affiliation & Expertise & Publication & Theory & Methodology \\
\hline Bai, J., 2013 & $\begin{array}{l}\text { Changchun } \\
\text { University }\end{array}$ & $\begin{array}{l}\text { Public } \\
\text { administration }\end{array}$ & Information science & $\begin{array}{l}\text { Principal-agen } \\
\mathrm{t} \text { theory }\end{array}$ & $\begin{array}{l}\text { Theoretical } \\
\text { analysis }\end{array}$ \\
\hline Chen, R., 2011 & People's Daily & Journalism & People's Daily & No & $\begin{array}{l}\text { Policy } \\
\text { analysis }\end{array}$ \\
\hline $\begin{array}{l}\text { Chinese } \\
\text { Ministry Of } \\
\text { Health, } 2005\end{array}$ & $\begin{array}{l}\text { Chinese Ministry } \\
\text { of Health }\end{array}$ & Public health & $\begin{array}{lr}\text { Beijing } & \text { Union } \\
\text { Medical } & \text { University } \\
\text { Press } & \end{array}$ & No & Database \\
\hline Deng, C., 2010 & $\begin{array}{l}\text { Yat-Sen } \\
\text { University }\end{array}$ & Sociology & PhD diss. & $\begin{array}{l}\text { Multi-level } \\
\text { participation }\end{array}$ & $\begin{array}{l}\text { Qualitative } \\
\text { analysis }\end{array}$ \\
\hline $\begin{array}{l}\text { Fan, C, G., } \\
2008\end{array}$ & $\begin{array}{l}\text { Renmin University } \\
\text { of China }\end{array}$ & Public policy & $\begin{array}{l}\text { Journal of China } \\
\text { National School of } \\
\text { Administration }\end{array}$ & $\begin{array}{l}\text { Information } \\
\text { theory }\end{array}$ & $\begin{array}{l}\text { Theoretical } \\
\text { analysis }\end{array}$ \\
\hline $\begin{array}{l}\text { Fan, C, J Jia, } \\
\text { and H Li., } 2012\end{array}$ & $\begin{array}{l}\text { Southwest } \\
\text { Jiaotong } \\
\text { University }\end{array}$ & Social economy & Management Review & Social trust & $\begin{array}{l}\text { Qualitative } \\
\text { analysis }\end{array}$ \\
\hline Gong, Y., 2013 & $\begin{array}{l}\text { Tianjin } \\
\text { Technology } \\
\text { University, }\end{array}$ & Risk assessment & Food Technology & $\begin{array}{l}\text { Risk } \\
\text { management }\end{array}$ & $\begin{array}{l}\text { Quantitative } \\
\text { analysis }\end{array}$ \\
\hline $\begin{array}{l}\text { Gu, } C \text {, and } Y \\
\text { An., } 2012\end{array}$ & $\begin{array}{l}\text { China agricultural } \\
\text { University }\end{array}$ & $\begin{array}{l}\text { Agriculture } \\
\text { development }\end{array}$ & $\begin{array}{lr}\text { Research } & \text { on } \\
\text { Economics } & \text { and } \\
\text { Management } & \end{array}$ & Game theory & $\begin{array}{l}\text { Theoretical } \\
\text { analysis }\end{array}$ \\
\hline Guo, F., 2016 & $\begin{array}{l}\text { Zhejiang } \\
\text { University }\end{array}$ & Public policy & Science Research & $\begin{array}{l}\text { Science } \\
\text { trust }\end{array}$ & $\begin{array}{l}\text { Theoretical } \\
\text { analysis }\end{array}$ \\
\hline $\begin{array}{l}\text { Guo, Q, L Tan, } \\
\text { and F Wang., } \\
2013\end{array}$ & $\begin{array}{l}\text { Shijiazhuang } \\
\text { Vocational } \\
\text { Technical Institute }\end{array}$ & $\begin{array}{l}\text { Agricultural } \\
\text { development }\end{array}$ & $\begin{array}{lr}\text { Journal of } & \text { Hebei } \\
\text { University } & \text { of } \\
\text { Economics } & \text { and } \\
\text { Business } & \end{array}$ & $\begin{array}{l}\text { Multi-level } \\
\text { governance }\end{array}$ & $\begin{array}{l}\text { Theoretical } \\
\text { analysis }\end{array}$ \\
\hline Hai, X., 2004 & $\begin{array}{l}\text { Fujian Quality and } \\
\text { Technology } \\
\text { Supervision } \\
\text { bureau }\end{array}$ & State supervision & $\begin{array}{l}\text { Fujian Province of } \\
\text { Quality and } \\
\text { Technology } \\
\text { Supervision }\end{array}$ & No & $\begin{array}{l}\text { Document } \\
\text { analysis }\end{array}$ \\
\hline $\begin{array}{l}\text { Han, Z, Q Liu, } \\
\text { and L Wang., } \\
2014\end{array}$ & $\begin{array}{l}\text { China Agricultural } \\
\text { University }\end{array}$ & $\begin{array}{l}\text { Agricultural } \\
\text { development }\end{array}$ & Rural Economy & $\begin{array}{l}\text { Multi-level } \\
\text { governance }\end{array}$ & $\begin{array}{l}\text { Theoretical } \\
\text { analysis }\end{array}$ \\
\hline
\end{tabular}




\begin{tabular}{|c|c|c|c|c|c|}
\hline $\begin{array}{l}\text { Hao, L., Li, D. } \\
\text { and } \\
\text { Liu, Y., } 2015\end{array}$ & $\begin{array}{l}\text { Chinese Academy } \\
\text { of } \\
\text { Sciences }\end{array}$ & $\begin{array}{l}\text { Agricultural } \\
\text { development }\end{array}$ & $\begin{array}{ll}\text { China } & \text { Rural } \\
\text { Observation } & \end{array}$ & $\begin{array}{l}\text { Cost-benefits } \\
\text { theory }\end{array}$ & $\begin{array}{l}\text { Quantitative } \\
\text { analysis }\end{array}$ \\
\hline He, Y., 2011 & $\begin{array}{l}\text { Tianjin } \\
\text { Technology } \\
\text { University }\end{array}$ & Economy & $\begin{array}{l}\text { Journal } \\
\text { Changchun } \\
\text { municipal } \\
\text { school }\end{array}$ & $\begin{array}{l}\text { Public } \\
\text { accountability }\end{array}$ & $\begin{array}{l}\text { Theoretical } \\
\text { analysis }\end{array}$ \\
\hline Kong, F., 2010 & $\begin{array}{l}\text { South China } \\
\text { Normal University }\end{array}$ & Law & $\begin{array}{l}\text { Journal of } \begin{array}{r}\text { South } \\
\text { China } \\
\text { University }\end{array} \\
\text { Normal } \\
\end{array}$ & No & $\begin{array}{l}\text { Document } \\
\text { analysis }\end{array}$ \\
\hline Lai, S., 2013 & $\begin{array}{l}\text { Huaqiao } \\
\text { University }\end{array}$ & Public policy & $\begin{array}{l}\text { Journal Public } \\
\text { management }\end{array}$ & $\begin{array}{l}\text { Institutional } \\
\text { perspective }\end{array}$ & $\begin{array}{l}\text { Quantitative } \\
\text { analysis }\end{array}$ \\
\hline $\begin{array}{l}\mathrm{Li}, \mathrm{H} \text {, and } \mathrm{W} \\
\text { Zhao., } 2009\end{array}$ & $\begin{array}{l}\text { Dongbei } \\
\text { University of } \\
\text { Finance and } \\
\text { Economics }\end{array}$ & Social Economy & $\begin{array}{l}\text { Research on } \\
\text { Financial and } \\
\text { Economic Issues }\end{array}$ & $\begin{array}{l}\text { Cost-benefit } \\
\text { theory }\end{array}$ & $\begin{array}{l}\text { Theoretical } \\
\text { analysis }\end{array}$ \\
\hline $\begin{array}{l}\text { Liu, D, and } Y \\
\text { Ge., } 2012\end{array}$ & $\begin{array}{l}\text { Shanghai Quality } \\
\text { Supervision and } \\
\text { Inspection } \\
\text { Technology } \\
\text { Research Institute }\end{array}$ & Risk Assessment & $\begin{array}{l}\text { Research on } \\
\text { Financial and } \\
\text { Economic Issues }\end{array}$ & No & $\begin{array}{l}\text { Document } \\
\text { analysis }\end{array}$ \\
\hline Liu, P., 2010 & $\begin{array}{l}\text { Renmin University } \\
\text { of China }\end{array}$ & Public policy & $\begin{array}{l}\text { Journal of Public } \\
\text { Administration } \\
\text { Research and } \\
\text { Theory }\end{array}$ & $\begin{array}{l}\text { Institutional } \\
\text { perspective }\end{array}$ & $\begin{array}{l}\text { Quantitative } \\
\text { analysis }\end{array}$ \\
\hline $\begin{array}{l}\text { Liu, } P \text {, and } S \\
\text { Zhang., } 2015\end{array}$ & $\begin{array}{l}\text { Renmin University } \\
\text { of China }\end{array}$ & Public policy & $\begin{array}{ll}\text { Journal of } & \text { Central } \\
\text { China } & \text { Normal } \\
\text { University } & \end{array}$ & $\begin{array}{l}\text { Political } \\
\text { power }\end{array}$ & $\begin{array}{l}\text { Theoretical } \\
\text { analysis }\end{array}$ \\
\hline $\begin{array}{l}\text { Liu, S, and H } \\
\text { Zhang., } 2010\end{array}$ & Hunan University & $\begin{array}{l}\text { Public } \\
\text { accountability }\end{array}$ & $\begin{array}{l}\text { PhD diss. Hunan } \\
\text { University }\end{array}$ & $\begin{array}{l}\text { Public } \\
\text { accountbaility }\end{array}$ & $\begin{array}{l}\text { Qualitative } \\
\text { analysis }\end{array}$ \\
\hline Ma, Y., 2007 & $\begin{array}{l}\text { Shanghai Normal } \\
\text { University }\end{array}$ & Law & $\begin{array}{l}\text { Peking University } \\
\text { Press }\end{array}$ & $\begin{array}{l}\text { Public } \\
\text { administration }\end{array}$ & $\begin{array}{l}\text { Theoretical } \\
\text { analysis }\end{array}$ \\
\hline Ma, Y., 2015 & $\begin{array}{l}\text { Shanghai Normal } \\
\text { University }\end{array}$ & Law & $\begin{array}{l}\text { Tsinghua Law } \\
\text { Journal }\end{array}$ & $\begin{array}{l}\text { Public } \\
\text { administration }\end{array}$ & $\begin{array}{l}\text { Theoretical } \\
\text { analysis }\end{array}$ \\
\hline $\begin{array}{l}\text { Nie, Y, and } \mathrm{H} \\
\text { Yan., } 2009\end{array}$ & $\begin{array}{l}\text { South China of } \\
\text { Normal University }\end{array}$ & Public policy & Social Science & $\begin{array}{l}\text { Multi-level } \\
\text { governance }\end{array}$ & $\begin{array}{l}\text { Theoretical } \\
\text { analysis }\end{array}$ \\
\hline Peng, F., 2009 & Hunan University & Law & $\begin{array}{l}\text { Journal of Gansu } \\
\text { Political Science and } \\
\text { Law Institute }\end{array}$ & $\begin{array}{l}\text { Science and } \\
\text { politic }\end{array}$ & $\begin{array}{l}\text { Theoretical } \\
\text { analysis }\end{array}$ \\
\hline Peng, F., 2010 & Hunan University & Law & $\begin{array}{l}\text { Journal of Gansu } \\
\text { Political Science and } \\
\text { Law Institute }\end{array}$ & $\begin{array}{l}\text { Public } \\
\text { accountability }\end{array}$ & $\begin{array}{l}\text { Theoretical } \\
\text { analysis }\end{array}$ \\
\hline $\begin{array}{l}\text { Qi, H, and } \mathrm{J} \\
\text { Tang., } 2014\end{array}$ & $\begin{array}{l}\text { Kunmin University } \\
\text { of Science and } \\
\text { Technology }\end{array}$ & Public policy & $\begin{array}{l}\text { Journal of Kunming } \\
\text { University of Science } \\
\text { and Technology }\end{array}$ & $\begin{array}{l}\text { Science and } \\
\text { trust }\end{array}$ & $\begin{array}{l}\text { Theoretical } \\
\text { analysis }\end{array}$ \\
\hline Qi, J., 2011 & $\begin{array}{l}\text { Zhongnan } \\
\text { University of } \\
\text { Economics and } \\
\text { Law }\end{array}$ & Law & Jianghuai Forum & $\begin{array}{l}\text { Science } \\
\text { trust }\end{array}$ & $\begin{array}{l}\text { Theoretical } \\
\text { analysis }\end{array}$ \\
\hline $\begin{array}{l}\text { Shao, M, and Z } \\
\text { Hu., } 2016\end{array}$ & $\begin{array}{lr}\text { East } & \text { China } \\
\text { University } & \text { of } \\
\text { Political Science } \\
\text { and Laws }\end{array}$ & $\begin{array}{l}\text { Public } \\
\text { administration }\end{array}$ & Finance Economics & $\begin{array}{l}\text { State } \\
\text { society }\end{array}$ & $\begin{array}{l}\text { Theoretical } \\
\text { analysis }\end{array}$ \\
\hline Tang, W., 2009 & $\begin{array}{l}\text { Chendu } \\
\text { University }\end{array}$ & Social issues & $\begin{array}{l}\text { Theory } \\
\text { Magazine }\end{array}$ & $\begin{array}{l}\text { Public } \\
\text { engagement }\end{array}$ & $\begin{array}{l}\text { Theoretical } \\
\text { analysis }\end{array}$ \\
\hline Wan, J., 2008 & $\begin{array}{l}\text { South China } \\
\text { Agricultural } \\
\text { University }\end{array}$ & Rural agriculture & Management World & Power theory & $\begin{array}{l}\text { Qualitative } \\
\text { analysis }\end{array}$ \\
\hline
\end{tabular}




\begin{tabular}{|c|c|c|c|c|c|}
\hline Wang, G., 2011 & $\begin{array}{l}\text { Renmin University } \\
\text { of China }\end{array}$ & Public policy & China reform & $\begin{array}{l}\text { Information } \\
\text { theory }\end{array}$ & $\begin{array}{l}\text { Theoretical } \\
\text { analysis }\end{array}$ \\
\hline Wang, K., 2012 & $\begin{array}{l}\text { Beijing } \\
\text { University }\end{array}$ & Agriculture & Economics Dynamic & $\begin{array}{l}\text { Public } \\
\text { administration }\end{array}$ & Review \\
\hline $\begin{array}{l}\text { Wang, } K \text {, and B } \\
\text { Li., } 2007\end{array}$ & $\begin{array}{ll}\text { Beijing } & \text { Wuzi } \\
\text { University } & \end{array}$ & Agriculture & Reform & $\begin{array}{l}\text { Public } \\
\text { administration }\end{array}$ & $\begin{array}{l}\text { Theoretical } \\
\text { analysis }\end{array}$ \\
\hline $\begin{array}{l}\text { Wang, } K \text {, and } X \\
\text { Su., } 2018\end{array}$ & $\begin{array}{l}\text { Beijing Wuzi } \\
\text { University }\end{array}$ & Public policy & Reform & $\begin{array}{l}\text { Public } \\
\text { administration }\end{array}$ & $\begin{array}{l}\text { Theoretical } \\
\text { analysis }\end{array}$ \\
\hline $\begin{array}{l}\text { Wang, L, J He, } \\
\text { and M Zhu., } \\
2009\end{array}$ & $\begin{array}{l}\text { Beijing Normal } \\
\text { University }\end{array}$ & Public policy & $\begin{array}{l}\text { China Administrative } \\
\text { management }\end{array}$ & $\begin{array}{l}\text { Public } \\
\text { administration }\end{array}$ & $\begin{array}{l}\text { Theoretical } \\
\text { analysis }\end{array}$ \\
\hline Wang, X., 2012 & $\begin{array}{l}\text { China Agricultural } \\
\text { University }\end{array}$ & Law & Jinnan Journal & $\begin{array}{l}\text { Risk } \\
\text { management }\end{array}$ & $\begin{array}{l}\text { Qualitative } \\
\text { analysis }\end{array}$ \\
\hline $\begin{array}{l}\text { Wang, } Z \text {, and } Y \\
\text { Mao., } 2008\end{array}$ & $\begin{array}{l}\text { Renmin University } \\
\text { of China }\end{array}$ & Agriculture & Food Policy & Public trust & $\begin{array}{l}\text { Theoretical } \\
\text { analysis }\end{array}$ \\
\hline Wei, C., 2013 & Xibei University & Economy & $\begin{array}{l}\text { Journal of Jiangxi } \\
\text { University of Finance } \\
\text { and Economics }\end{array}$ & $\begin{array}{l}\text { Public } \\
\text { administration }\end{array}$ & $\begin{array}{l}\text { Theoretical } \\
\text { analysis }\end{array}$ \\
\hline Wu, Y., 2012 & $\begin{array}{l}\text { Southwestern } \\
\text { University of } \\
\text { Finance and } \\
\text { Economics }\end{array}$ & Law & $\begin{array}{l}\text { Chinese Social } \\
\text { Sciences }\end{array}$ & $\begin{array}{l}\text { Public } \\
\text { administration }\end{array}$ & $\begin{array}{l}\text { Theoretical } \\
\text { analysis }\end{array}$ \\
\hline Wu, Y., 2013 & $\begin{array}{l}\text { Southwestern } \\
\text { University of } \\
\text { Finance and } \\
\text { Economics }\end{array}$ & Law & $\begin{array}{l}\text { Study on the Law } \\
\text { and Business }\end{array}$ & Social trust & $\begin{array}{l}\text { Theoretical } \\
\text { analysis }\end{array}$ \\
\hline $\begin{array}{l}\mathrm{Xu}, \mathrm{H} \text {, and L } \\
\text { Xu., } 2008\end{array}$ & $\begin{array}{l}\text { H Xu: China } \\
\text { National Center } \\
\text { for Food Safety } \\
\text { Risk; L Xu: } \\
\text { Haerbin } \\
\text { commercial } \\
\text { University }\end{array}$ & Risk assessment & China Forestry Press & $\begin{array}{l}\text { Public } \\
\text { administration }\end{array}$ & $\begin{array}{l}\text { Theoretical } \\
\text { analysis }\end{array}$ \\
\hline $\begin{array}{l}\text { Yan, } H \text {, and } Y \\
\text { Nie., } 2009\end{array}$ & $\begin{array}{l}\text { South China of } \\
\text { Normal University }\end{array}$ & Public policy & $\begin{array}{l}\text { Journal of Public } \\
\text { management }\end{array}$ & $\begin{array}{l}\text { Public } \\
\text { administration }\end{array}$ & $\begin{array}{l}\text { Theoretical } \\
\text { analysis }\end{array}$ \\
\hline Yang, X., 2012 & $\begin{array}{l}\text { Zhongnan } \\
\text { University of } \\
\text { Finance and } \\
\text { Economics }\end{array}$ & Law & $\begin{array}{l}\text { Administrative Law } \\
\text { Research }\end{array}$ & $\begin{array}{l}\text { Risk } \\
\text { management }\end{array}$ & $\begin{array}{l}\text { Theoretical } \\
\text { analysis }\end{array}$ \\
\hline Yuan, D. , 2014 & $\begin{array}{l}\text { Southern } \\
\text { Weekend }\end{array}$ & Journalism & Southern Weekend & No & $\begin{array}{l}\text { Policy } \\
\text { analysis }\end{array}$ \\
\hline $\begin{array}{l}\text { Zhang, } \quad \text { X., } \\
2005\end{array}$ & $\begin{array}{l}\text { Journal of } \\
\text { International Food } \\
\& \quad \text { Agribusiness } \\
\text { Marketing }\end{array}$ & Public policy & $\begin{array}{l}\text { Journal of } \\
\text { International Food \& } \\
\text { Agribusiness } \\
\text { Marketing }\end{array}$ & Public trust & $\begin{array}{l}\text { Qualitative } \\
\text { analysis }\end{array}$ \\
\hline $\begin{array}{l}\text { Zhang, } \quad \text { C. } \\
2009\end{array}$ & Jinan University & Agricultural policy & $\begin{array}{ll}\text { Gansu } & \text { Social } \\
\text { Science } & \end{array}$ & $\begin{array}{l}\text { Co-governanc } \\
\text { e }\end{array}$ & $\begin{array}{l}\text { Qualitative } \\
\text { analysis }\end{array}$ \\
\hline $\begin{array}{l}\text { Zhang, F, Y } \\
\text { Fan, and } \quad B \\
\text { Ren., 2007 }\end{array}$ & Xibei University & $\begin{array}{l}\text { Business and } \\
\text { economy }\end{array}$ & $\begin{array}{l}\text { Zhengzhou Academy } \\
\text { for Economical } \\
\text { Administration press }\end{array}$ & $\begin{array}{l}\text { Transaction-c } \\
\text { ost theory }\end{array}$ & $\begin{array}{l}\text { Theoretical } \\
\text { analysis }\end{array}$ \\
\hline $\begin{array}{l}\text { Zhang, } \quad \text { G., } \\
2007\end{array}$ & Peking University & Public policy & $\begin{array}{l}\text { Peking University } \\
\text { Press }\end{array}$ & $\begin{array}{l}\text { Public } \\
\text { administration }\end{array}$ & $\begin{array}{l}\text { Theoretical } \\
\text { analysis }\end{array}$ \\
\hline $\begin{array}{l}\text { Zhang, } X \text {, and } \\
\text { C Sun, } 2008\end{array}$ & $\begin{array}{l}\text { Central University } \\
\text { of Finance and } \\
\text { Economics }\end{array}$ & Agriculture & $\begin{array}{l}\text { Economic System } \\
\text { Revolution }\end{array}$ & $\begin{array}{l}\text { Principal-agen } \\
\text { t theory }\end{array}$ & $\begin{array}{l}\text { Theoretical } \\
\text { analysis }\end{array}$ \\
\hline
\end{tabular}




\begin{tabular}{|c|c|c|c|c|c|c|}
\hline $\begin{array}{l}\text { Zhu, A, W } \\
\text { Chang, L Liu, } \\
\text { and C Zhu., } \\
2013\end{array}$ & $\begin{array}{l}\text { A Zhu \& C Zhu: } \\
\text { Fudan University; } \\
\text { W Chang \& L Liu: } \\
\text { Second Military } \\
\text { Medical University }\end{array}$ & Public policy & $\begin{array}{l}\text { Naval } \\
\text { Journal }\end{array}$ & Medical & $\begin{array}{l}\text { Information } \\
\text { theory }\end{array}$ & $\begin{array}{l}\text { Theoretical } \\
\text { analysis }\end{array}$ \\
\hline
\end{tabular}




\section{Chapter 3}

Stakeholder Perspectives on Infant Formula Safety Governance in China: A Decade after the Melamine Crisis 


\begin{abstract}
This paper critically engages with dynamics of the Chinese food safety governance infrastructure following the melamine crisis. It presents a qualitative analysis of sixteen in-depth stakeholder interviews in Hunan, Hubei and Henan. We reveal tensions between a segmented model of governance and a centralised model, between a centralised top-down model and stakeholder participation, and between a public model and a private, decentral market where corporate reputation must result in transparency and trust. Stakeholders also see gaps between ideals of inclusive, transparent and participatory governance, and effective problem-solving. Governance of food safety in China, even when targeting inclusion and public accountability, remains heavily dependent on the central state as a pivotal actor.
\end{abstract}




\section{Introduction}

In 2008, infant milk sold in China by Sanlu was contaminated with melamine and water. By the end of September, six children had died from the effects of melamine poisoning and a further 300,000 consumers suffered kidney stones and renal failure because of melamine exposure (Holtkamp et al., 2014; Pei et al., 2011). During the escalation of this incident, the Chinese central state ordered an emergency risk assessment report (Liu \& Liu, 2009), showing that melamine had been detected in the infant formula sold by twenty-two domestic companies including Yili, Mengniu, Bright Dairy, Shengyuan, and Yashili. This caused great concern - some may say panic - about the safety of China's infant formula (Wang, 2008). From this moment onward, the Chinese dairy industry experienced a trust crisis as well as huge setbacks in its development (Zhang and Zhou, 2008; Gong and Jackson, 2012). Over a decade, associated governance structures and especially accountability structures, have attempted to rebuild public trust.

Daniell and Kay (2017) argue that the essence of an accountability system associated with food safety is that it provides regulations to restrain bureaucracy, inaction, buck-passing and blame-avoiding in state actors, impelling them to take responsibility on food safety supervision, information disclosure, and risk management. Their envisioned ideal accountability system ensures information transparency to the public and promotes communicative interaction (justification and discussion) between agents and citizens. Additionally, accountability structures should ensure that if an incident occurs, rectification including compensation or sanctions apply, in order to protect citizens' interests, and to hold actors accountable (Bovens et al., 2014).

Chinese scholars who studied and discussed accountability structures surrounding the scandal argued that an 'accountability deficit' was the primary cause of the so-called 'milk scandal' (Delman and Yang, 2012). Feng (2011) argued that the relevant dairy companies should be held accountable by the state, including the raw milk producing households, illegal staff at the raw-milking purchasing stations who added melamine, and the companies who sold the melamine-tainted infant formula. $\mathrm{Ge}$ and Peng (2012) stressed that the dairy companies should assume responsibility of civil compensation to victims, as well as receive legal punishment. Others argued that accountability surrounding the milk scandal should not be limited to the market. Li (2009) explains that local governments, responsible for food safety supervision, have to be held accountable as well. Song et al. (2017) illustrate this by showing that local governments focused on stimulating economic development and market interests at the expense of food safety. More concretely, Le and Chen (2018) argue that the quality of melamine-detection in milk power (timeliness and effectiveness) by the Bureau of Quality and Technical Supervision is poor and Yan (2010) and Peng et al. (2015) showed that local governments tend to conceal food safety scandals and protect local companies rather than support information transparency. 
This led several scholars to conclude that the whole accountability structure was flawed and shared in the responsibility for the milk scandal, through defective procedures and regulations, bureaucratic culture, and unclear responsibilities following from segmented supervision patterns (Liu and Yan, 2011; Song et al., 2012; Xu, 2014). With respect to the issue of power distribution, Huang (2011) argues that unclear responsibility boundary setting between supervising departments led to power-overlaps and power-vacuums, and buck-passing. According to Huang, power centralisation in government in the form of a coordination agency could have tackled these issues. However, Lai (2013) and Wang and Li (2007) argue that power centralisation is not a solution, as it will create absolute power over food safety, and with it, corruption, and ultimately a failure of accountability. To Liu (2010), Lai (2014) and Edwards (2015), the traditional concepts of a food safety supervision system as a controlling and regulating organisation monopolised by the state is outdated and unable to restore public trust. The Chinese academic debate around food safety exhibits a trend towards co-governance and stakeholder participation in the governance of infant formula safety. These movements emphasise participation and consultative dialogue between decision makers and interest parties and invite public debate, interaction, and inclusiveness (Yang et al., 2020).

Inspired by these conceptual developments in accountability around food safety, coinciding with changes in the Chinese food safety control systems (Jia and Jukes, 2013), we empirically study the accountability dynamics around the Chinese milk scandal. We ask how diverse stakeholders attribute meaning to changing accountability infrastructures and dilemmas associated with infant formula safety governance. We ask whether different stakeholders, officials as well as non-officials, perceive this historical developmental trajectory of infant formula safety governance and its future differently.

This study aims to, primarily, empirically chronicle perspectives and views on the development of governance of food safety in China, and secondarily, provide input to discuss the feasibility of concepts such as democratic accountability, stakeholderism, and multi-level governance, developed in Western, academic and political discourses, in the Chinese context.

\section{Methods}

To study in the dynamics of the governance of infant formula safety and public trust in China, we qualitatively studied the perspectives of relevant stakeholders on food safety governance, supplemented with a policy document analysis. We focused on three main themes: (1) government and the accountability system, (2) risk assessment, and (3) risk communication. These themes were determined to be the most salient, based upon a review and analysis of Chinese academic literature on food safety governance (Yang et al., 2020 ).

The empirical core of the study consists of interviews with diverse stakeholders in the Chinese provinces of Hubei, Hunan and Henan. Data was collected through 16 semi-structured interviews 
with food safety experts, government representatives, employees of dairy companies, media professionals, and consumers (see table 1 for a more detailed overview). The study sample was purposefully selected: participants were approached based upon their experience, expertise and involvement in the governance of infant formula safety in their region.

Table 1: Informants characteristics and description of function

\begin{tabular}{|c|c|c|}
\hline Informant ID & Gender & Description \\
\hline ID1 & Female & $\begin{array}{l}\text { Vice Dean; Public Health Bureau; supervising the safety of primary food } \\
\text { production }\end{array}$ \\
\hline ID2 & Male & $\begin{array}{l}\text { Director; Industrial and Commercial Bureau; focused on circulation of dairy } \\
\text { products in market }\end{array}$ \\
\hline ID3 & Male & $\begin{array}{l}\text { Dean; Food and Drug Bureau; supervising infant formula safety, risk control } \\
\text { and consumers complaints }\end{array}$ \\
\hline ID4 & Female & $\begin{array}{l}\text { Vice Dean; Animal Husbandry and Veterinary Bureau; focused on } \\
\text { supervising cow-breeding safety }\end{array}$ \\
\hline ID5 & Male & $\begin{array}{l}\text { Vice Dean; Quality and Technical Supervision Bureau; focused on personnel } \\
\text { training, food safety communication \& technological support }\end{array}$ \\
\hline ID6 & Female & Vice Director; Agricultural Bureau; supervising catering safety \\
\hline ID7 & Male & Expert; Risk Assessment Centre \\
\hline ID8 & Male & $\begin{array}{l}\text { Professor; Agriculture University; focused on food safety supervision and } \\
\text { governance }\end{array}$ \\
\hline ID9 & Male & Expert; Food Safety Communication Centre \\
\hline ID10 & Female & Journalist; Media \\
\hline ID11 & Male & Editor; media \\
\hline ID12 & Male & Manager; Dairy Company \\
\hline ID13 & Male & Executive; Cow-breeding factory \\
\hline ID14 & Female & Infant formula retailer \\
\hline ID15 & Female & Young mother; using domestic infant formula \\
\hline ID16 & Female & Young mother; using foreign infant formula \\
\hline
\end{tabular}

In the interest of establishing access and trust with potential respondents, we informed them about the academic aims of the interviews. Prior to the interviews, a very concise interview guide summarising the research's main objectives and themes was provided to all respondents. The interview guide listed the following themes: (a) transitions of power distribution in supervising departments, (b) development of political and social accountability systems, (c) information disclosure and information transparency, (d) risk assessment and the value of expertise. These themes were operationalised in questions about concrete processes, activities or practices in the specific organisations employing the respondents, or, in the case of the interviews with young mothers, their private lives. Accordingly, the questionnaire used was tailor-made. In order to achieve an in-depth understanding of the governance of infant formula safety and public trust in China, the interviews were semi-structured, providing room for respondents to tell their story as they saw fit. 
The interviews were conducted between February and April 2018 in China (Hubei, Hunan and Henan provinces) and were conducted in Chinese. All quotes reproduced here were translated by RY. The interviewees were recruited through personal relationship networks instead of official appointment-making methods, in light of the sensitivity of the topic of infant formula safety in both government and dairy companies. For the same reason, in most cases, interviews could not be conducted as the respondents' work places, and interviews could not be recorded. We encountered multiple sensitivities, for instance, Chinese local government officials were privately restrained by their superiors to talk to strangers or journalists about controversial topics. The source of such restrictions is the so-called 'second session' (the second session of the 12th National Committee of the Chinese People's Political Consultative Conference) in March 2018, concerning the potential issues such as online rumour management, as well as governmental reputational damage. Detailed note taking and verbatim transcription from memory immediately afterwards, allowed us to maintain original connotations and quotes for our analysis.

Subsequent thematic analysis was guided by the theoretical discussions about governance and accountability (Bovens et al., 2014). Important themes that we identified most often and that we stressed the most by respondents were the supervision and accountability system, risk assessment, information disclosure and supervision dilemmas. We identified more detailed sub-themes via deductive manual iterative coding of the data ${ }^{4}$. Subsequently, exemplary data extracts were selected from the key sub-themes for inclusion as quotes (Collins, 2019).

\section{Results}

Accountability infrastructures involve a number of elements or stages: information, claims and transparency, explanations and discussions, and the imposition of remedies, including possible sanctions or rectification (Mulgan, 2014). In order to understand how stakeholders and respondents frame problems with accountability structures in China, we display edited stakeholder narratives on governance and accountability structures, risk assessment and risk communication.

\subsection{Governance and accountability}

In 2004, several years before the infant formula scandal, a new segmented supervision system was set up by the Chinese central state. It distributed responsibilities for food category across governmental departments with different expertises on both national and local level (Fan, 2004). State actors

\footnotetext{
4 These sub-themes include accountability \& supervision at central level; accountability \& supervision at local level; value of expert; information disclosure at central level; information disclosure at local level; risk communication between expert and public; accountability deficits.
} 
explained that this multi-sector supervision system meant that every supervision body maintained its specific expertise. An official in a local Public Health Bureau summarised this as follows:

The Agricultural Bureau was responsible for the supervision on primary agricultural products, the Public Health Bureau focused on the market sector, the Quality and Technical Bureau stressed regulation on the food processing, and the Food and Drug Bureau focused on the coordination of food safety supervision and manage food safety incidents. (ID1)

Another official, at the Industrial and Commercial Bureau, offers a rationale for why this infrastructure was required:

The increasingly complex food chain at the turn of $21^{\text {st }}$ century in China had disabled the single supervision body to regulate food safety risks efficiently. As response, multi-level supervision bodies were created to assure food safety from farm to table. (ID2)

Officials in the Quality and Technical Supervision and the Agriculture Bureau argued that these distributions of tasks and responsibilities were far from perfect, required constant maintenance and, in some case, supplementary policies. Yet despite these deficits, they argued it remained effective, especially after a series of food regulatory tools, such as food safety analysis and evaluation policies, food recall procedures, and food additive control, were amended:

To forage a professional supervision system, an array of technical instruments, such as scientific food hazard control measures, procedural food recall mechanism and standardized sample inspection were utilized to improve the food safety regulatory efficiency. (ID5)

However, a member of the Food and Drug Supervision Bureau voiced criticism on segmented accountability. He argues that supervision on infant formula safety through the segmented model was very likely to cause unclear responsibility boundaries among supervision bodies, resulting in both power overlaps and-vacuums:

The outbreak of Melamine Milk Scandal was primarily ascribed to the unclear responsibilities setting among regulatory agencies. The regulatory agencies pass the buck each other, resulting in Melamine in milk not being founded. (ID3)

An official in a local Animal Husbandry and Veterinary Bureau admitted that indeed such deficits existed in the segmented model. She pointed out that the Food Safety Commission, a coordination agency at the council level was established in 2010 specifically to overcome power overlaps and vacuums (ID4). She argues: 
Complementarily, Food Safety Commission was created for allocating task to the different regulatory agencies, building the collaboration mechanism among multi-level departments, ascertaining the causality of food regulators malpractice and food safety incidents, and holding officials accountable. (ID4)

In contrast, an academic we interviewed offered unveiled critique, stressing that a coordination agency was nowhere near enough. Neither the centralised model nor the segmented model was adequate. The 'human' factor caused supervision deficits which ought to be taken into account, requiring Chinese central state intervention (ID8). He described this intervention as follows:

To deter abuse power such as power-renting and official-business collusion among local officials, the central state enacted "Outlines of Administrative Accountability of Local Officials" following the Melamine Milk Scandal. (ID8)

An official in the Food and Drug Bureau underlines this narrative, arguing that the administrative accountability system played an active role after the melamine scandal in 2008, hampering information transparency, initiation and implementation of remedies as well as restoring public trust in governments (ID3). As an immediate consequence, a reporter at Hubei Daily news we spoke to, argued that, the "five dragons" (five supervision bodies) involved in the milk chain supervision at both national and local level must be held accountable:

When consumers reported the tainted Sanlu milk to regulatory agencies, no one responded. If measures were adopted promptly, the tragedy could have been avoided. The outbreak of milk scandal was primarily ascribed to official malpractice and official-business collusion. They should be punished stringently. (ID3)

Managers at both a dairy company and a co-breeding factory stress that the relevant companies involved in melamine milk production chain must be accountable too, including the melamine-producers, -retailers, -adders, and Sanlu company in particular (ID12,13). One of them argues:

These players in dairy supply chain intentionally misused, adulterated and sold milk with melamine, causing death and illness of babies. They should be sentenced. (ID12)

Where managers and the journalist above point to concrete actors and their accountability, the academic quoted above directs his critique to the level of the infrastructure. Not merely the governments and companies but the accountability infrastructure itself, the segmented model, exposed unclear responsibility boundary setting and should itself be held answerable for the melamine incident: 
A coordination agency failed to settle power vacuum and overlap in the segmented model and an ex post facto accountability was unable to deter abuse of power. (ID8)

On top of this, the accountability deficits criticised above in terms of its procedures, regulations, dynamics, relief system and cultures, also gave rise to account-holders playing 'hide and seek' with the public and the media (ID3,8):

The state leaders conventionally found scapegoats to take responsibilities for the food safety incidents. Meanwhile, several officials who were punished for wrongdoing in the aftermath of the scandal got promoted or reinstated. The public accountability system in China seems to just keep officials out sight for a while, like they are on a vacation. (ID3)

Against this background, an official in the Food and Drug Supervision Bureau explains that a centralised supervision model and a strict accountability system were created by the Chinese central state after the milk scandal, to tackle issues of unclear responsibility boundary setting and accountability deficits (ID3).

In 2013, the central state enacted regulations to merge the regulatory agencies at the local level. Meanwhile, the central state updated Food Safety Law in 2015, in which a stringent government accountability was created to constrain misfeasance of governmental actors. (ID3)

The professor and journalists we interviewed argued independently from one another that this new centralised supervision model is likely to suffer from the corruption that comes with absolute power that lacks an efficient accountability system. They called for external accountability structures populated by other stakeholders beyond government to help alleviate this (ID8, 10, 11). The professor explains those calls were, in part, taken into account:

Complementary to the centralized model, co-governance system emphasized construction of collaborative network that enabled diverse actors to engage in food safety governance to promote information transparency, scrutinize governmental behaviour and maintain their respective benefits and values. (ID8)

However, journalists argue that the established administrative accountability system is not as effective as portrayed by officials (ID10, 11). They invoke an event that took place 2013-2016 concerning Abbott milk powder to show that local supervision bodies were still unable to carry out administrative accountability as structured above, because they again found means to avoid blame and pass the buck:

Despite the increasing consumer complaints about quality issues in Abbott infant formula between 2013 and 2016, regulatory agencies refused to conduct investigations and hold Abbott 
accountable on the ground of that the quality of Abbott has been certified by states, the evidence provided by consumers was insufficient and the lack of transregional mechanism disabled local states to handle complaints about unsafe food purchased from other places. (ID10)

A journalist at Hubei Daily News argues that in this case victims had to seek out the media and third party allies themselves. Non-governmental stakeholders were sought to hold Abbott accountable after government structures:

Media reports about Abbott safety issues have fuelled widespread public concern. To alleviate the pressure of public opinion pressure, Abbott had to compensate victims. Nonetheless, Abbott company still claimed no safety issue in milk aiming to shirk responsibilities and maintain corporate reputation. (ID11)

These new additions to a more informal accountability infrastructure, outside of government control, encountered active resistance. A journalist in Xiaoxiang encountered many instances of such resistance and offers an example. For instance, third party testing institutions lacked state authorisation, allowing Abbott to question their legitimacy:

CER research, a third party testing agency, released outcomes of risk assessment in December 2013, claiming the quality of Abbott milk failing to meet national standards. Abbott openly doubted the legitimacy of CER and the accuracy of risk assessment reports. Meanwhile, Abbott contacted and induced risk assessors who involved in the milk quality risk assessment to deny the accuracy of these reports. Subsequently, the debates between Abbott and CER escalated, resulting in that citizens did not who was credible. (ID10)

As a consequence, our journalist respondent argues, social accountability thus came to a deadlock, not solely due to a lack of legitimacy and authority granted by the state, but because of a lack of collaborative structures among non-state stakeholders (ID11).

Against this backdrop, Chinese central state had to intervene again, to curb institutional fragmentation and weak incentives in the accountability infrastructures at the local level. Reporters describe that the central state was powerful enough to 'simply' instruct local government to take administrative accountability towards Abbott in May, 2014 (ID10, 11). As one of journalists argues:

Nearly 17,000 cans of defective Abbott infant formula were sold in Chinese market in last five years. To conduct effective regulation on milk, the central state established intergovernmental collaboration mechanism at local levels to hold Abbott and other illegal sellers. Meanwhile, the central state conducted a strict risk assessment on Abbott infant formula to ensure milk safety. (ID10) 
Stakeholders display different attitudes and experiences towards the segmented or centralised accountability infrastructures, as well as with respect to possibilities to participate in newer social accountability structures. Officials disagree on the distribution of responsibilities and the location of accountability and in the light of (re-)centralisation, academics and journalists call out for more public participation in accountability infrastructures. The current accountability infrastructures risk that local governing bodies continue to avoid blame and passed the buck around. Other stakeholders attempt to take up critical roles to facilitate transparency and discussion, but are severely limited because, as non-state actors, they lack state authorisation to do so. A consequence of this is that they are left on their own and participate in an accountability infrastructure in isolation, lacking any mutual coordination.

\subsection{Risk assessment and public trust}

A risk expert we interviewed, argued that 'a shift from food safety crisis response to risk management is deemed crucial to the construction of food safety governance models, in which risk assessment is the most technical part' (ID7). Risk assessment is treated as scientific basis for the formulation of standards and political decision-making. However, a reporter we interviewed argues that Chinese science keeps very close ties with politics in risk assessment (ID10). A member of a risk assessment committee is not so concerned about this:

Experts in risk assessment committees were affiliated and salaried by the state. They conducted scientific investigation and provided evidence for governmental decision-making. Meanwhile, citizens trusted experts and believed they are capable to make professional decisions. (ID7)

As a series of food safety incidents occurred, journalists argue, experts and the wider public grew to perceive risk differently, ultimately leading to the view that "Experts were conspiring with politics" (ID10). More and more scientific experts were enlisted by the state to speak truth on its behalf, which was criticised as 'science entangled with government' (ID10). A journalist argues:

Before 2008 China Milk Scandal, experts of risk assessment committee were the spokesperson of states to legitimatize the decision-making and conducted science popularisation to improve public trust in states. (ID10)

This exists in stark contrast with requests by citizens for independent expert risk assessment without state intervention (ID15). However, in the Chinese context of 'big government, small society' ${ }^{5}$, risk assessment was unlikely to remain independent as experts were keen to secure status through

\footnotetext{
5 In the Chinese context, the term "Big government, Small society" was defined in the "planned economy" movement of Chinese academic views in the 1930-1940s.
} 
institutional resources as well as government affiliation. One of the academics we interviewed argues that "In risk assessment, the more resources the experts relied on from the state rather than social organisations, the more those experts listened to the government" (ID9).

Another academic points out that in an attempt to counteract the government affiliation and preferences of experts, and cater to diverse risk perceptions among stakeholders, a mechanism for public participation in risk assessment, to help facilitate pluralistic discussion, was in fact created by the central state in 2010, after the 2008 milk scandal. He argues,

Now the national risk assessment committee is no longer composed of single political experts, but policy-makers, but is consist of experts from academic institutions, hospitals, laboratories, third party, and enterprises. They, representing different benefits and values, discuss, bargain and compromise during the risk assessment, favoring information transparency. (ID8)

Nonetheless, journalists identify a deficit in public participation in risk assessment. Citizens share the concern that the contemporary risk assessment system has not formed the desired pluralistic interaction between scientific experts, policy-makers, representatives of business, NGO and citizens (ID15, 16). A reporter confirms the view that consumers continue to be mere recipients of policy as opposed to actors in the science-policy nexus. This flows from policy-makers and scientific assuming that lay people cannot conceptualise the scientific uncertainties associated with technical risk assessment (ID10).

A media editor underlines the issue that expertise and technologies applied for risk assessment constrain lay public engagement (ID11). To overcome this problem, he argues that third party testing institutions could act as the representatives of public to engage in technical risk assessment.

In contrast, a journalist stresses that for third party testing agencies to participate in risk assessment fully, their authority and independence would have to be raised first. She argues that otherwise, it would very likely diminish public trust when the third party agencies expressed mostly or only business interests (ID10).

However, a professor argues that there are many forms of knowledge (including but not limited to scientific, managerial and lay knowledge) and that different risks and strategies stem from different contexts. Citizens should be considered lay experts who are entitled to epistemic justice (Fricker 2007), similar to experts in the technical deliberations to contribute knowledge (ID8). That is, a measure of respect for the experiential knowledge they bring into risk assessment of food safety:

In general, technical experts conduct risks assessment on defective food reported by citizens, but they lack the persistent monitor on food supply chain. In contrast, the public tends to keep more attention on food quality and has developed rich experience to detect food safety issues 
to ensure individual health. Integrating lay expertise and experience would help to detect and mitigate food safety risks. (ID 8)

While the risk assessment expert is satisfied with current assessment infrastructures, academics, and journalists each express their own concerns. This results in a tension between the top-down model supported by the expert, and public participation supported by non-state actors. After the milk scandal, a compromise was reached. It allows other stakeholders beyond the government to participate in risk assessment. As of 2015, the Chinese central state allows them to discuss, bargain and compromise with one another, with the purpose of counteracting the association of risk and risk perception with the state alone, and, ultimately, to building public trust, even though doubt was cast on the public understanding of science. The process, however, continues to be highly orchestrated by the central state.

\subsection{Risk communication and transparency}

Next to accountability, and risk assessment infrastructures, knowledge claims and information discourse are of primary importance to transparency and public perception of infant formula safety. An expert in risk communication argues that the way information is disclosed can contribute to perceived uncertainties on food safety and affect public risk perception as well as public trust (ID9).

An official in the Public Health Bureau explained that since 2004 a top-down segmented information disclosure system was put in place, referring to five supervision bodies involving in food chain, releasing their information associated with food safety individually. Compared to the preceding command-and-control approach, one of the Bureau's officials argues, citizens could access the information in each link of the food safety production chain:

With the increasingly risky food chain, it is necessary to establish information traceability system to ensure information transparency from farmer to table, and players in food chain were accountable for food safety issues. (ID1)

However, journalists vigorously oppose this view. They argue that the information asymmetry and information confusion among public specifically caused by the segmented model were by-no-means negligible. This segmented model allowed power overlaps and -vacuums to occur (see above) and they recognised similar problems in information disclosure (ID10, 11):

Bureaucratic fragmentization caused conflicted and inaccurate information disclosure. Meanwhile, segmented model brought about power vacuum. To avoid the pressure of public opinions and top-down accountability, some local regulatory agencies concealed negative information and kept delay and inaction in information disclosure. (ID 11) 
An official in the Quality and Technical Supervision Bureau, drawing from similar arguments, explains that for this reason a coordination agency was established in 2015: to achieve unitary information release and sharing with the purpose of information asymmetry and to avoid public confusion:

A coordination agency was created to negotiate food safety regulation to curb power overlap and vacuum. Meanwhile, this coordination agency was responsible for information sharing among multiple-level apparatuses to facilitate uniform information disclosure of food safety. (ID5)

Nonetheless, one of the academics we interviewed maintains that a divergence existed between the information transparency suggested to exist, and the perceived transparency by the public (ID8). Additionally, local governments cannot solely perform food safety governance as increasingly intricate food safety issues emerge, non-state stakeholders are required to participate, such as food producers. A professor argues:

With the increasingly risky food supply chain, states are unable to ensure food safety solely. Enterprises and societal actors should be involved to promote information transparency. Meanwhile, reciprocal risk communication between diverse stakeholders should be established to favour public trust. (ID8)

After the 2008 milk scandal, risk communication and information disclosure became and continues to be a contested topic (Zhu et al., 2019). Officials and other experts disagreed on whether disclosure and communication were adequate and who should participate. After 2008, in practice, a market-focus emerged. This meant that some of the responsibilities were delegated to producers and consumers through information traceability systems. The purpose of these systems was to mitigate uncertainties by providing information 'from farm to fork' in terms of infant formula safety. In them, the government provided legal and regulatory support, all food chain actors are informants and, citizen participate as non-state supervisors (ID8-11, 15). Nevertheless, despite disagreement persisting, citizens recognised advantages:

The online infant formula information traceability system was established by the state in 2013 to allow players in food supply chain to upload relevant information. Citizens are eligible to trace these information, and they can give comments and share experience for milk purchase on this system, which will effect consumers' purchase choice and corporate reputation. To obtain a good regulation, enterprises are competitive to keep information transparency. (ID15) 
However, journalists continue to point out the deficiencies in the information traceability system in terms of the authority of information providers and the accessibility of information, as well as high investment costs for businesses and continued risk of abuse. A journalist argues:

The construction and operation of information traceability need much financial investment, signifying that business cost of enterprises will increase, decreasing enterprises' motivation to utilize traceability system. Meanwhile, due to the complicate food supply chain in China, information of milk safety from farm to table is unable to be recorded in this system. Moreover, consumers have to access to the information via special application, decreasing the use rate among citizens. (ID10)

Officials operating under the segmented as well as central accountability infrastructure consider government the most efficient at risk communication and building public trust. In contrast, journalists and academics express their worry about the conflict between information exposed by both governments and companies and transparency perceived by public. They call for supplementing information traceability with public participation to benefit for transparency and public trust. When it comes to talking about risk, stakeholders in the food safety chain display significantly different positions when it comes to who ought to be involved and why.

\section{Discussion}

Our study shows that stakeholders engaged in discussing dynamics of infant formula governance view the governance and accountability landscape and its changes differently. Officials stress government reform, aiming to improve the efficiency of governance through various means such as the central model replacing the segmented model, strict accountability, top-down risk assessment, and segmented information disclosure facilitated by a coordination system. Academics stress the need for a decentral forum where other stakeholders beyond government participate in governance and share accountability, rather than the public sphere being included nominally, a position largely shared with the young mothers we talked to. Members of the media perceive risks and benefits critically, as well as sceptically approaching the co-governance system where and when centralised models and public participation were fused. They continue to stress potential risks, such as the weak incentives associated with the top-down model, extremely limited capacity of public participation, and the lack of authority for third parties in the decentral market.

As Chinese scholars previously documented, food safety governance and accountability systems exhibits movements towards both decentralisation and recentralisation of power (Cai, 2015; Gul, 2016; Yi, 2013). Simultaneously, stakeholderism cautiously found its way into accountability, risk communication and risk assessment, while simultaneously top-down control over local enforcement 
agencies was intensified (Yang et al., 2020). Unsurprisingly, in the light of the development described above, the accountability system was subject to a lot more resistance than many Chinese authors suggested (Liu and Sun, 2015; Wen, 2013). Non-governmental stakeholders diagnosed gaps between ideals and outcomes of the accountability infrastructure. While those ideals stressed inclusive approaches to governance, consisting of top-down model and stakeholderism, actual practices exhibited at least three consistent features undermining those ideals. These are, first, that local supervision bodies were dodging responsibility, avoiding blame and passing buck in the infant formula scandal by straightforwardly denying responsibility and suppressing evidence. Second, other stakeholders beyond government were in practice unable to hold a company accountable (Abbott, in this case) and social accountability thus was not allowed to develop in full. Third, central state still remains to be the pivotal player to activate vertical accountability and perform any true imposition of remedies. The Chinese situation does not offer non-state actors, the ability or authority to hold governments accountable, except when specifically authorised by that very same state. Differently from, as Warren (2014) argues, seeing the core of accountability in democracy and participation beyond the state, accountability in China very much centres on the state.

Our analysis also shows that despite being extremely limited, social accountability structures do operate in China. Stakeholder participatory accountability often allows for more information disclosure and public debate. However, because they lack all types of power allowing enforcement themselves, they need to provoke the executive branch of the state to take remedial action through the power of adverse publicity and potential reputational damage (Collins and Quinlivan, 2009). Nonetheless, neither the state nor the public is able to solely complete an accountability infrastructure where a number of stages or complex systems including reporting, informing, and discussing, imposition of remedies were involved (Mulgan, 2014).

\section{Conclusion}

The pivotal role of Chinese central state, which stepped in as the final authority in the milk scandal case, as it did in so many other cases, obscures the dynamics of accountability in Chinese society. Responsibilities and power, as well as the associated tasks of giving account and providing information, are perpetually contingent, limiting the ways in which our frames of understanding apply. Nonetheless, we can conclude that Chinese food safety governance infrastructures, and in their wake, risk assessment and risk communication infrastructures associated with infant formula, suffered from a specific, tripartite accountability deficit (Daniell and Kay, 2017). A range of issues need to be solved, including the development of collaborative mechanisms amongst non-state actors, alleviating the weak capacity of public, trade-off of power distribution between state and stakeholders, weak 
incentives and institutional fragmentation in local government before achieving desirable accountability and multi-level governance.

\section{References}

Bovens, M., Goodin, R. E. and Schillemans, T., 2014. The Oxford handbook public accountability. Oxford University Press.

Cai, C., 2015. From "big government" to "wise government": the logic of Chinese government transformation_ from the perspectives of transaction cost and politics. Public Administrative Review 2, pp. 99-124.

Collins, H., 2019. Forms of Life: The Method and Meaning of Sociology. MIT Press.

Collins, N. and Quinlivan, A., 2009. Multi-level governance. In: Coakley, J. and Gallagher, M. eds. Politics in the Republic of Ireland. Routledge, pp. 359-380.

Daniell, K., \& Kay, A., 2017. Multi-level Governance: An Introduction. In: A Daniell, K. and Kay, A., ed. Multi-level Governance: Conceptual challenges and case studies from Australia. The Australian National University Press, pp. 3-32.

Delman, J. and Yang, M., 2012. A Value Chain Gone Awry: Implications of the "Tainted Milk Scandal" in 2008 for Political and Social Organization in Rural China. In A Bislev, and Thogersen., B. Eds. Organizing Rural China, Rural China Organizing. Lanham: Lexington Books. pp. 205-221.

Edwards, M. E., 2012. Food insecurity in Western US states: Increasing collaboration between state agencies and nonprofit organizations. Food, Culture \& Society 15(1), pp. 93-112.

Fan, X., 2004. Taking responsibility on the shoulders_-Director Zheng.Y talks about implementing the "Decision of the State Council on Further Strengthening Food Safety Work". Journal of Chinese Food Safety Supervision 5, pp. 4-7.

Feng, H., 2011. Accountability, Regulatory Performance, and Economic States - Reflections on the Status of Public Security Incident Accountability. Law Review 3, pp. 21-8.

Fricker, M., 2007. Epistemic injustice: Power and the ethics of knowing. Oxford University Press: Oxford, UK.

Ge, Y. and Peng, Y., 2012. Food safety supervision situation and suggestions for small food workshops and small vendors. Legal Expo 12(1), pp. 25-6.

Gong, Q. and Jackson, P., 2012. Consuming anxiety? Parenting practices in China after the infant formula scandal. Food, Culture \& Society 15(4), pp. 557-578.

$\mathrm{Gu}, \mathrm{X} ., 2016$. Optimal government scale, coordinated economic and social development and dispute between big government and small government. Study and Explore 1, pp. 85-91.

Holtkamp, N. Liu, P. and McGuire, W., 2014. Regional patterns of food safety in China: What can we learn from media data? China Economic Review, 30, pp. 459-468.

Huang, X., 2011. Solving the dis-function of accountability system-from the perspective of food safety supervision. Administrative Management Reform 9, pp. 36-39.

Jia, C. and Jukes, D., 2013. The national food safety control system of China-a systematic review. Food Control 32(1), pp. 236-245.

Lai, S., 2013. Accountability, inertia and publicity: research on local governments' behavior based on 97 cases of public crisis. Public Administration Journal, 2, pp. 18-27.

Lai, S., 2014. Power Allocation, Accountability and Local Government Food Safety Supervision Performance: Controversy and Inspection. Public Administrative Review. 7(2), pp. 120-42.

Le, M. and Chen, W., 2018. Analysis of institutional changes and policy characteristics of China's dairy industry under the food safety crisis. Finance and Economics, 231, pp. 105-113.

Li, X., 2009. Discussion on China's food safety supervision system from melamine incident. China Food Hygiene Magazine, 21, pp. 208-211.

Liu, N. and Liu, X., 2009. Issues and countermeasures of milk dairy safety in China. Financial economics monthly, 6, pp. 101-102.

Liu, P., 2010. Tracing and periodizing China's food safety regulation: A study on China's food safety regime change. Regulation \& Governance 4(2), pp. 244-260.

Liu, Y. and Yan, C., 2011. From change toward progress: the experience from Melamine incident. Wuhan University Journal (Philosophy \& Social Sciences), 2, pp. 80-7. 
Mulgan, R. 2014. Accountability deficits. In: Bovens, M., Goodin, R. E. and Schillemans, T. (Eds.). The Oxford handbook of public accountability. Oxford: Oxford University Press, pp. 545-559.

Pei, X., Tandon, A., Alldrick, A., Giorgi, L., Huang, W. and Yang, R., 2011. The China melamine milk scandal and its implications for food safety regulation. Food policy, 36(3), pp.412-420.

Peng, Y., Li, J., Xia, H., Qi, S. and Li, J., 2015. The effects of food safety issues released by we media on consumers' awareness and purchasing behavior: A case study in China. Food Policy, 51, pp.44-52.

Song, Y., Cao, H. and Lv, C., 2017. Analysis of spatial effects of food safety regulation. China Science and Technology Forum, 9(3), 127-134.

Song, Y. and Wei, X., 2012. Administrative accountability system building in food safety supervision in China. China Administrative Governance 12(2), pp. 56-58.

Wang, K. and Li, B., 2007. Food safety issues and regulation. Exploration 4, pp. 44-47.

Wang, X., 2008. Yili, Mengniu, Bright Dairy milk also contains melamine. New Finance, 10, pp. 92.

Warren, M. E. 2014. Accountability and democracy. In M Bovens, R.E Goodin, \& T Schillemans (Eds.), The Oxford Handbook of Public Accountability. Oxford University Press. pp. 39-54.

Wen, H., 2013. Analysis and countermeasures on the governmental buck-passing in the emergency. Political Research, 6(3), pp. 52-60.

Xu, X., 2014. Problems and countermeasures in accountability system of food safety supervision. Theoretical Exploration, 4(3), pp. 71-74.

Yan, H., 2010. Reform of China's Food Safety Supervision System_—Based on the Analysis of the Holistic Government Theory. Academic Research, 5, pp. 43-52.

Yang, R., Horstman, K. and Penders, B., 2020. Constructing the accountability of food safety as a public problem in China: a document analysis of Chinese scholarship, 2008-2018. Journal of Chinese Governance, pp.1-27.

Yi, S., 2013. Analysis of "Small Government", "Big Society" and "Civil Society". Marxism Research, 9 (3), pp. 128-133.

Zhang, H. and Zhou, F., 2008. The food safety regulation system and China milk scandal. Theoretical Exploration, 6, pp.145-147.

Zhu, X., Huang, I. Y. and Manning, L., 2019. The Role of Media Reporting in Food Safety Governance in China: A Dairy Case Study. Food Control, 96, pp. 165-179. 


\section{Chapter 4}

Addressing Vaccine Hesitancy in China: A Scoping Review of Chinese Scholarship 
Published as Yang, R., Penders, B. \& Horstman, K. (2020). Addressing Vaccine Hesitancy in China: A Scoping Review of Chinese Scholarship. Vaccines 8 (1): 2.

\begin{abstract}
Despite the well-developed Chinese National Immunization Program, vaccine hesitancy in China is rising. As part of the response, Chinese scholars have studied determinants and proposed solutions to vaccination hesitancy. We performed a scoping review of Chinese literature (2007-2019), drawn from four Chinese databases. We mapped relevant information and presented a systemic account of the proposed determinants and responses to vaccine hesitancy in China. We identified 77 relevant studies that reveal four approaches to vaccine hesitancy. Most Chinese studies define vaccine hesitancy as a problem of vaccine safety and vaccine incident response and place accountability on the level of governance, such as regulation deficits and inappropriate crisis management. A first minority of studies tied vaccination hesitancy to unprofessional medical conduct and called for additional resources and enhanced physician qualifications. A second minority of studies positioned vaccination hesitancy as a problem of parental belief and pointed to the role of media, proposing enhanced communication and education. Chinese literature ties vaccine hesitancy primarily to vaccine safety and medical conduct. Compared to international research, parental concerns are underrepresented. The Chinese context of vaccination scandals notably frames the discussion of vaccination hesitancy and potential solutions, which stresses the importance of considering vaccination hesitancy in specific social and political contexts.
\end{abstract}




\section{Introduction}

Four decades after the start of China's National Immunization Program (NIP) for children in 1978, a complete vaccine chain and a strict regulation system up to the WHO standards have been established in the country (McLaughlin, 2016; Chen, 2017). The Chinese vaccination program distinguishes between Category 1 and Category 2 vaccines. Category 1 vaccines are provided for free for all children until 14 years, and the use of these vaccines is - although not mandatory-considered a social duty (Ministry of Health, 2019). Category 1 vaccines include vaccines to prevent diseases, such as the hepatitis B vaccine, Bacillus Calmette-Guérin vaccine, polio vaccine, diphtheria-tetanus-pertussis (DTP) vaccine, and MMR vaccine. Children are vaccinated at the local centre for disease control (CDC) or affiliated agencies before they enter school, join the army, or go abroad. Category 2 vaccines are optional vaccines and that have to be paid for by the parents. The vaccines in this category include, for instance, vaccines to prevent human papillomavirus (HPV), mumps, rubella, pneumococcus, and rotavirus. The coverage of Category 1 vaccines is higher than that of Category 2 vaccines and, sometimes, the authorities consider moving a vaccine from Category 2 to Category 1 -as is currently the case with the pneumococcal vaccine - to reduce suffering among children (Wagner et al., 2017). According to a report by the national CDC, the Category 1 vaccination rate in China in 2019 was higher than $90 \%$, which is among the highest in the world (Ministry of Health, 2019).

A systematic review of global studies on vaccination hesitancy identified only one Mandarin study published in 2007 and two studies of vaccination hesitancy in China published in English journals (Larson et al.,2014). Dube et al. (2014) aimed to map vaccine hesitancy globally on the basis of interviews with immunization managers, no Chinese interviewees were included. Nevertheless, vaccine hesitancy is considered an important problem in China (Wagner et al., 2017; Ren et al., 2018). In the last decade, a series of reports about the serious side-effects of vaccination has increased vaccination hesitancy and distrust in the immunization program (Yu et al., 2016). In 2010, media outlets reported on vaccination-induced disability and questioned the death of nearly a hundred 
children due to the uptake of invalid vaccines that were exposed to high temperatures (Chen et al., 2015). In 2014, it was reported that eight babies died after hepatitis vaccination in southern China (Chen et al., 2015), and in 2016, a large number of expired vaccines circulated in Shansong Province caused public anxiety (Liu et al., 2018). In 2018, the Changsheng company falsified records of vaccine production, and as a result, children were injected with unqualified vaccines, leading to panic among parents nationwide (Cacere, 2018). These incidents have eroded people's confidence in China's NIP. According to (Zhang, 2017), after the Hepatitis B vaccine crisis of 2014, 30\% of parents started doubting vaccination. In a survey conducted by Wang et al. (2019) in a city in the Shandong province, $77.78 \%$ and $87.78 \%$ of parents expressed their doubts about Category 1 and 2 vaccinations, respectively, after the Shandong vaccine crisis of 2016. According to (Tong, 2019), after the Changsheng vaccine crisis of 2018, 93.4\% of parents in Yangzhou had less trust in Chinese vaccines. In line with this reduced trust, the vaccination rate dropped. Affected by the 2014 Kangtai hepatitis vaccination problems, the hepatitis vaccination rate dropped by $30 \%$ in 10 provinces. In 2016 , the vaccination rates for a few Category 2 vaccines, especially the rotavirus vaccine, decreased massively. The rates of rotavirus vaccine, Hemophilus influenzae type $\mathrm{b}$ vaccination and varicella live attenuated vaccination decreased by $20.49 \%, 40.60 \%$, and $28.26 \%$, respectively, compared to those in 2015 (Zhou et al., 2018). In addition, owing to the effects of these vaccine safety crises, the Category 2 influenza vaccination rate stood at only $2 \%$ in 2018 (Peng et al., 2018).

Vaccine hesitancy was defined by the WHO in 2015 as a delay in acceptance or refusal of vaccination despite availability of vaccination services (Dube et al., 2014). Building on the definition of vaccine hesitancy, the WHO Strategic Advisory Group of Experts (SAGE) drafted a "Model of determinants of vaccine hesitancy" in 2012, organized around three key domains. These are 1) contextual influences - including historic, social-cultural, environmental, health system/ institutional, economic, or political factors; 2) individual and group influences-including influences arising from personal perception of the vaccine or influences of the social/peer environment; and 3) vaccine and vaccination-specific issues, which are directly related to the characteristics of the vaccine or the vaccination process (Dube et al., 2014; Larson et al., 2014). Most studies have focused more on individual and group influences and contextual influences than on vaccine-related issues (Sadaf et al., 2013; Geelen et al., 2016; Jarrett et al., 2015). Accordingly, education of, communication with, and information dissemination to parents are collectively considered an important strategy globally. Studies on vaccination hesitancy in China published in international journals paint a similar picture. For instance, it has been argued that the public lacks adequate vaccine knowledge and is unable to recognize the risks of vaccination ( $\mathrm{Li}$ et al., 2018). The authors of these study advised that the Chinese state should launch educational campaigns to improve parental awareness and knowledge of vaccination. Along similar lines, Chen et al. (2015) and Yue et al. (2016) have argued that media 
coverage of vaccine incidents have amplified public concerns and fuelled vaccine hesitancy. According to Chen et al. (2015), to counteract these media influences, an online communication mechanism should be established by the state to engage with the public in a timely manner, avoid misinformation, immediately launch an investigation to determine the clinical situations of causality, and monitor public confidence.

However, other internationally published studies on vaccination hesitancy in China have not focused on parental considerations and the influences of media on parental decisions but instead on the governance of vaccine safety. Yuan (2018), Caceres (2018) and Zhou et al. (2019) have argued that pharmaceutical enterprises are responsible for the vaccine-related scandals in China and that the government should reform the supervisory model to strengthen regulation of the vaccine chain from production to market and to alleviate public anxiety. Similarly, Liu et al. (2015) argued that the surveillance system of Adverse Events Following Immunization played a major role in stimulating distrust because the system was unable to collect sufficient data about the side effects of vaccination and underreported the social impact of such side effects. According to Liu et al. (2015), the government should strengthen its surveillance capacity and develop a new, active surveillance system.

To provide more insights into vaccination hesitancy in China, we aim to analyse how vaccination hesitancy and the governance of vaccination hesitancy in China are studied in Chinese academia. Most studies on the governance of trust in vaccination in Chinese academia focus either on a specific case study (Wang and He, 2016) or on a subset of governance strategies (e.g., crisis management, accountability of enterprise) (Hu, 2014). A systematic exploration of studies on this topic is yet to be conducted. To address this gap, we conducted a scoping review of Chinese publications. We analysed a specific set of publications by focusing on three main questions: How is the problem of vaccine hesitancy defined? How are the responsibilities for this problem allocated? What are the proposed solutions?

\section{Materials and Methods}

To perform a scoping review, we followed the framework proposed by Arksey and O'Malley (2005), supplemented with the PRISM-ScR extension for scoping reviews in as much as possible given the different information contained in Chinese databases and research papers (Tricoo et al., 2018). This framework can be divided into five stages: (1) Identification of the research questions; (2) identification of relevant studies; (3) study selection; (4) data charting; and (5) reporting the findings.

\subsection{Identifying Research Questions}


This scoping review aims to study how Chinese scholars have analysed the governance of the Chinese NIP: How have they defined the problem, how have they assigned responsibility, and which solutions have they proposed? The purpose is to map and understand the Chinese academic and professional debate about vaccine hesitancy and to highlight areas for further analysis.

\subsection{Identifying Relevant Studies}

To identify relevant studies, we focused on scholarly and grey literature about the governance of vaccine hesitancy in China published between 2007 and September 2019. The starting point was set to 2007 because we did not find any research on vaccine hesitancy published before 2007. We consulted four China databases, namely China National Knowledge Infrastructure (CNKI), Baidu Scholar (BS), Wanfang (WD), and Chongqing (CVIP), which index academic and professional articles, government reports, and public commentaries. Chinese databases employ slightly different demarcation criteria for scholarship and index some semi-journalistic publications. Since Chinese research infrastructure considers them to qualify as scholarship, we did not exclude them. These four databases are widely used by Chinese scholars, and they are considered authoritative by academics and professionals. We searched these databases on scope, including the title and abstract. Aiming to obtain insights into the scholarly debate on the governance of vaccines and concerns surrounding vaccination in China, the following search terms were selected: vaccine concern, vaccination concern, vaccine incident response, safety issue and cause, enterprise production, media report, supervision system, medical staff, risk assessment, public participation, assessment criteria, risk communication compensation system, and countermeasures.

\subsection{Selection of Relevant Studies}

Following an electronic search, titles and abstracts were screened and full articles were reviewed to determine whether they met the eligibility criteria. The inclusion and exclusion criteria are listed in Table 1.

Table 1. Selection criteria for study inclusion and exclusion.

\begin{tabular}{|c|c|}
\hline Inclusion & Exclusion \\
\hline $\begin{array}{l}\text { 1. Scholarly peer-reviewed articles, conference papers, } \\
\text { government reports, media reports. }\end{array}$ & $\begin{array}{l}\text { 1. Publications that only mentioned vaccine safety } \\
\text { in the conclusions. }\end{array}$ \\
\hline $\begin{array}{l}\text { 2. Papers focused on governance of vaccination and } \\
\text { public trust. }\end{array}$ & $\begin{array}{l}\text { 2. Papers focused on preclinical medicine and } \\
\text { veterinary medicine research. }\end{array}$ \\
\hline
\end{tabular}

\subsection{Charting Data}


We recorded all relevant publications in a spreadsheet, including information about authors, publication year, authors' expertise, disciplinary focus, category of vaccine hesitancy (demarcating four sets of problem/responsibility/solution conceptualisations) (see Table A1). We screened the articles based on how the authors defined the problem of vaccine and vaccination concerns, how they assigned responsibility for the problem, and which measures they proposed.

\subsection{Presentation of Results}

We present the results by organizing them into five sections: How many relevant articles were selected? How do scholars define the problem of vaccine hesitancy? How did they assign responsibility for the problem? Which measures did they propose? How did they respond to new policies?

\section{Results}

\subsection{Selected Articles}

We identified 1200 papers, out of which 250 papers were excluded because they were repeatedly presented in four databases, resulting in 950 papers (see Figure 1). After title and abstract screening, 90 papers were included for full text screening. Out of the 90 articles, 32 papers were excluded for the following reasons: 17 articles focused on the analysis of microbial vaccines, 7 articles studied foreign vaccines, 5 only mentioned vaccines in the conclusions, and 4 had overlapping content. In case of overlap or duplication, we included the oldest publication in the set. In addition, 20 new articles which were not part of the original search results $(n=1200)$, were included after bibliography screening, as a result of divergent terminological use. Finally, 77 relevant articles were identified for inclusion in the review. 


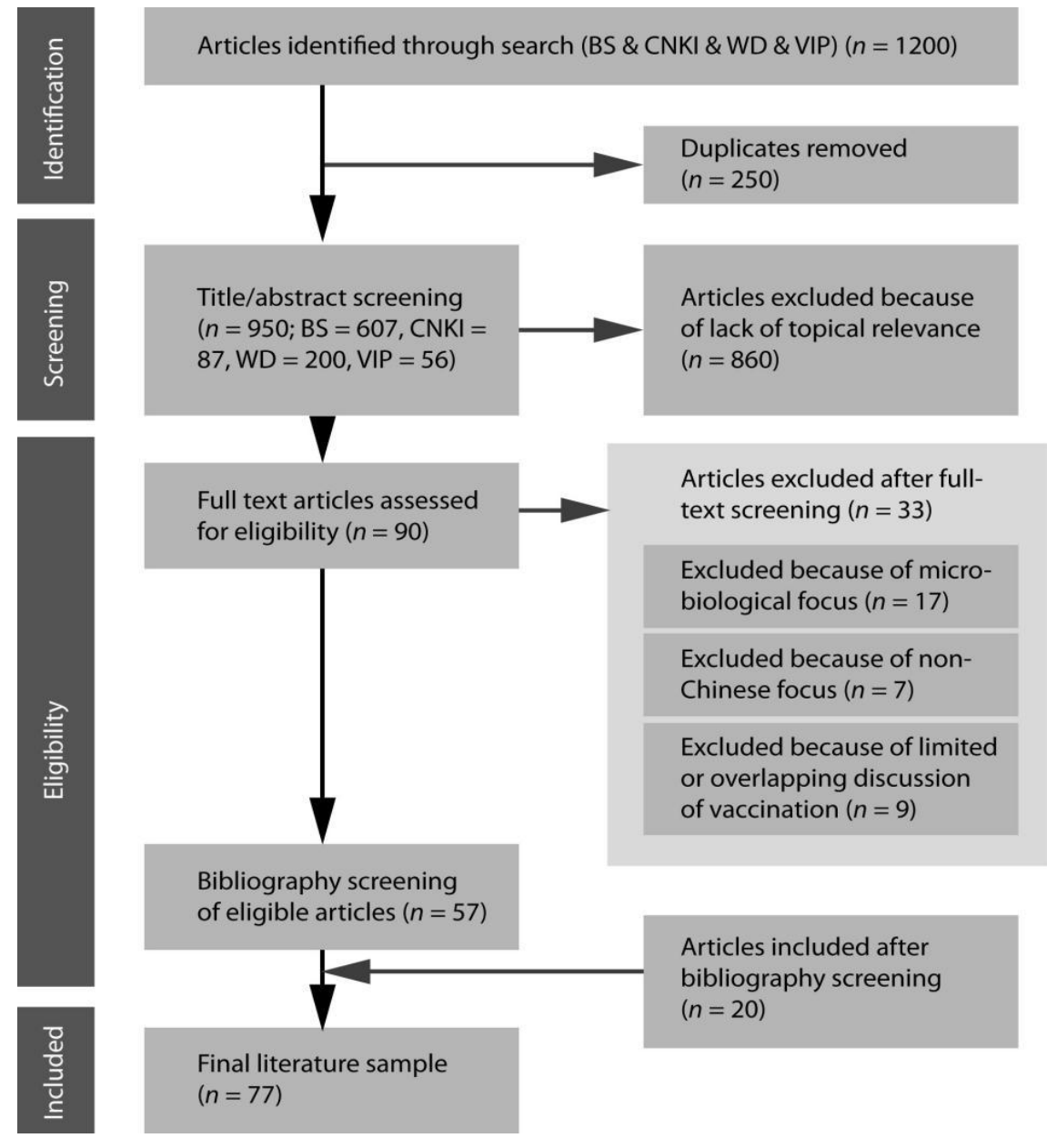

Figure 1. PRISMA chart.

\subsection{Defining the Problem of Vaccine Hesitancy}

Among the selected articles, we distinguished four different approaches to vaccine and vaccination hesitancy, namely vaccine safety $(n=35)$, vaccine incident response $(n=17)$, professional conduct $(n$ $=12$ ), and parental concerns $(n=13)$ (see Figure 2). This categorisation is based on the three research questions, focussing on the description of the problem, the group assigned responsibility for that problem, and the proposed solutions. Most of the studies focused on unsafe-vaccine-induced hesitancy, and an increasing number of studies on this topic were published between 2010 and 2019 . Although the number of studies on parental concerns has increased gradually over the last seven years, such studies were a minority. Most articles on incident response were published between 2014 and 
2019, which may be affected by the hepatitis B vaccine incident of 2014, illegal vaccine event of 2016 in Shandong, and Changsheng vaccine scandal of 2018.

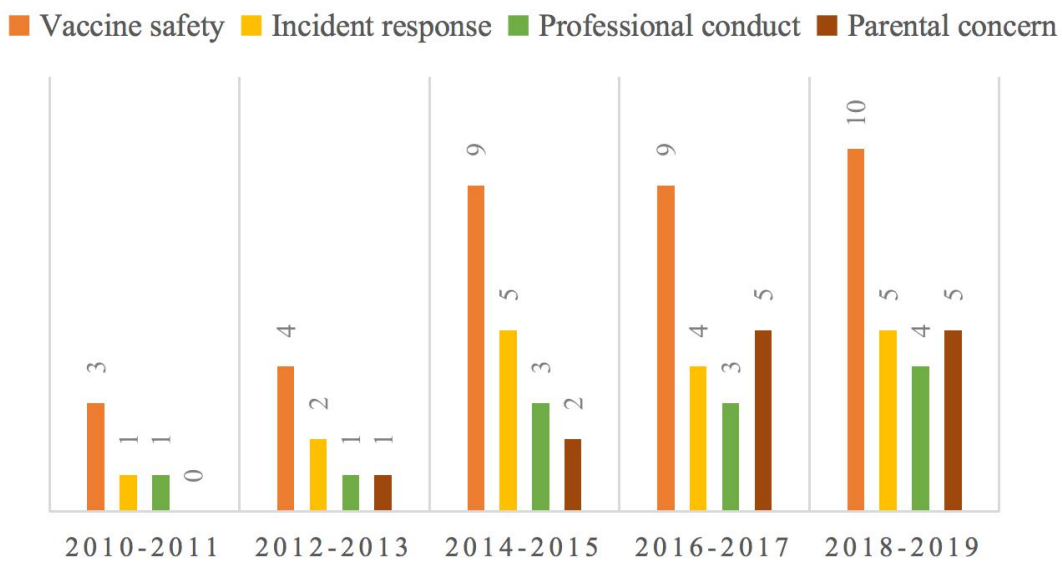

Figure 2. Distribution of publications on the governance of vaccine hesitancy across four categories during 2010-2019. Categories were assigned based upon problem articulation, solution proposals, and the allocation of responsibility (see Section 3.2).

\section{Vaccine Safety}

Most scholars have argued that vaccine hesitancy can be ascribed to unsafe vaccines. Enterprises adopted illegal production techniques and falsified production records, leading to huge risks related to vaccine safety (Sun et al., 2015; Li et al., 2016; Chinese Administrative Management Group, 2018; Liu et al., 2017). This resulted in parents believing that vaccines are unsafe and may harm the health of their children (Tong, 2019). According to epidemiologists, unqualified refrigeration decreases the efficacy of vaccines, which is unfavourable for disease prevention and reduces public trust in vaccine safety (Sun, 2014; Yu et al., 2014; Di, 2015; Ma, 2015; Chen et al., 2016; Shi, 2017; Yuan and Li, 2017; Zheng, 2017).

Scholars have pointed to illegal corporate production, supervision model deficits, state-business collusion, and bureaucratic production system as routes for understanding the presence of unsafe vaccines. Some social scientific studies have indicated that driven by commercial profits, enterprises produced problematic vaccines, which were used to inoculate many children nationwide (Meng and $\mathrm{Xu}, 2012$ ). When this fact was disclosed by the media, companies responded by suppressing evidence and shirking responsibilities, and according to the authors, they should be punished severely for these acts (Meng and Xu, 2012; Hu, 2014; Wang, 2016; Lu, 2018). Moreover, a couple of public policy scholars have stressed that the bureaucratic production system leads to price 
squeezing in vaccines, and to obtain profits, enterprises must produce vaccines illegally (Qian and Wang, 2012; Chen et al., 2015).

Furthermore, sociologists and public policy experts Zheng (2014) and Zhou and Li (2014) have argued that local state leaders who collude with companies to further their economic interests and for self-career advancement are responsible for problematic vaccines. They administer the distribution of state resources and prioritize the disbursal of loans to enterprises via power and rent-seeking, which provokes commercial bribery (Zhou and Li, 2014). Moreover, to spur local economic development and favour the promotion of their political careers, local leaders connive in corporate violations, which weakens the governmental supervision capacity to some extent (Zhang, 2014).

A handful of scholars in the fields of public policy have proposed that supervision mode deficits are to blame for problematic vaccines. They have argued that the Chinese horizontally segmented regulatory model with less collaboration among supervisory bodies leads to power overlaps and vacuums, which hinders strict supervision of the vaccine industrial chain from production to market (Li, 20111; Jiang et al., 2014; Li, 2019). Meanwhile, owing to reformation of the vertical hierarchical regulatory system in 2012, daily supervision tasks are top-down reallocated at the grassroots supervisory departments. Consequently, grassroots governments that lack experienced medical staff and advanced technologies have been unable to complete the highly technical supervision tasks, thus weakening the state's capacity to enforce regulations pertaining to vaccine safety (Zhang, 2018).

\section{Vaccine Incident Response}

Along similar lines, several social policy researchers have noted that public distrust should be attributed to failed crisis management efforts on the part of the state and experts, for example, risk assessment and risk communication of vaccine incidents. The lack of public participation and lack of information transparency in risk assessment ( $\mathrm{Lu}, 2018)$, as well as suspicions about state-expert conspiracy, have reduced the credibility of expert risk assessment (Lai, 2013; Qi and Cheng, 2015; Han, 2016). Lai (2013) have argued that a qualification entry setting restrains the participation of the lay public and that experts privatize data and keep the process non-transparent in an attempt to reduce disputes and pressure from the society. Moreover, they argue experts conventionally give voice to the public interest and public values in China. Yet they are now subject to politics, which has spurred distrust (Lai, 2013; Qi and Cheng, 2015).

The lack of systematic risk communication is related to public distrust as well. Journalists have argued that because local officials are concerned about accountability, they tend to restrain the dissemination of negative information when crises occur and have little regard for information transparency and risk communication in an attempt to reduce social concerns (Sui, 2014; Xiao, 2017; 
Song, 2018; Song, 2018). In addition, there are no special personnel and specific policies and strategies to support systematic communication between the state and public, leading to increased distrust of the state (Xiang, 2012; Huang, 2018; Zhao et al., 2018).

\section{Professional Conduct of Vaccination}

In addition to vaccine safety and incident response, Chinese scholars have related the professional conduct of vaccination personnel to vaccination concerns. Epidemiologists have argued that pre-vaccination contraindication intimation and post-vaccination observation for 30 min could reduce the occurrence of vaccination side effects and increase trust in the vaccination process ( $\mathrm{Yu}, 2016$; Yang, 2017). However, in practice, doctors exhibit little regard for pre-vaccination screening and post-vaccination observation, stressing instead on completion of the vaccination task (Cheng et al, 2014; Liu, 2015). In addition, doctors are impatient and not very responsive to questions during vaccination, which causes the public to be dissatisfied with medical services (Wang, 2012; Guo et al., 2018). Furthermore, the use of relatively old technologies at the grassroots level, such as old refrigeration systems and unqualified information traceability mechanisms, are to blame for reduced trust (Zhao et al., 2016; Zhou et al., 2017; Qiao et al., 2018).

\section{Parental Concern}

Other scholars have pointed out the contribution of parents to increased vaccination hesitancy. A public health expert has argued that declined trust in vaccination can be ascribed to the cognitive biases of parents (An et al., 2018). Parents consider vaccination as highly risky and keep doubting vaccines, which results in public distrust and decreases the rate of Category 2 vaccination (Liu et al., 2018). According to epidemiologists (Peng et al., 2018), owing to parental hesitancy, the average annual flu vaccination rate in China stand at only $2 \%-3 \%$. In addition, in $2017,40.5 \%$ of parents in western China were hesitant to vaccinate their kids against EV71 (Tang, 2018). However, several CDC experts have argued that imprecise reports in the media stimulated parental distrust: eye-catching titles, such as "toxic vaccine," "life-killing vaccine," and "fearing and screaming" further stimulated parental risk perception and parental concerns (Yang, 2017; Dai and Zhu, 2018). Epidemiologists (Cao et al., 2012; Ma, 2016; Yu, 2016) have also argued that parents do not have adequate cognitions on the hazards of epidemics and the benefits of vaccination, resulting in the distrust of vaccines. Zhuang and Wang (2016) have emphasized that the lengthy queues for vaccination, bad attitude of medical staff, and lack of communication increased public dissatisfaction in vaccination. In addition, An et al. (2018) have focused on the poor accessibility of vaccines because of the high prices of Category 2 vaccines, or the need to travel far affected the registration system, since children in some places were required to accept Category 1 vaccination in their town of 
birth. Researchers have highlighted the prevalence of vaccination hesitancy among medical staff, which leads to negative publicity about vaccines (Qiao, 2018).

\subsection{Defining Solutions for Reducing Vaccination Hesitancy}

In line with the different ways in which Chinese academics have defined the problem of vaccination hesitancy, studies have focused on different strategies to deal with the problem. A dozen studies have called for a centralized model to supervise vaccination safety. Before 2000, vaccines were distributed top-down by the state, and local governments were responsible for vaccine hygiene regulation. Owing to strict political control over the vaccination infrastructure at that time, adverse incidents related to vaccines rarely occurred (Kunming CDC, 2018a). In 2010, in response to the expansion of the vaccination program and the increasing complexity of the vaccine chain, a segmented model was introduced: Five different supervisory bodies assumed responsibility for vaccine safety in different phases of the vaccine chain (Hu, 2014; Chinese Administrative Management Group, 2018; Kunming CDC, 2018b). However, with the emergence of vaccine incidents, the segmented model was again centralized to tackle the power vacuum and overlap (Yu et al., 2016; Xue and Li, 2018). Moreover, a strict administrative accountability mechanism was introduced to restrain illegal production and official malpractice (Yi and Liao, 2013).

In addition to improvements to the supervisory model, some scholars have suggested that the system for controlling the cold chain should be improved as well. Public health experts have advised that vaccine-related risks be classified, equipment updated, standard operation procedure regulation (SOP) enacted, regular risk assessment of refrigeration carried out, and information traceability through good data management established (Zhang and Chen, 2010; Zhou et al., 2017).

Several studies have emphasized that professional medical conduct should be regulated. A group of public health experts have proposed that the vaccination standards be raised, such as pre-vaccination screening and post-vaccination follow-up (Wu, 2013; Yang and Ding, 2014). During vaccination, communication between doctors and parents could be improved, information could be shared, and professionals could be more responsive to questions and doubts (Wang, 2018). To increase the accountability of doctors (Feng, 2014; Yang and Ding, 2014), information systems for recording data, such as the health status of a child and vaccination procedure, should be improved. Other scholars have focused on creating entry qualifications for doctors and implementing regular training and annual assessments for doctors to improve their skills (Wen, 2011; Zhong et al., 2017). Advanced refrigeration equipment, medicinal freezers, and alarm devices for temperature should be adopted at hospitals to ensure vaccine safety ( $\mathrm{Wu}, 2013)$.

A handful of scholars have argued for a so-called participatory turn during incident response. Sociologists (Sui, 2014; Xiao, 2017) have suggested that risk assessment procedures should allow 
stakeholder participation, and discussion should be conducted with these stakeholders to ensure the fairness of risk assessment and prevent data falsification by experts. Several scholars have proposed a systematic risk communication system to facilitate expert-public communication (Song, 2015). Furthermore, several scholars have highlighted the importance of adequate compensation mechanisms to tackle crisis-led public distrust. They have argued in favour of expanding the scope of compensation to cover all vaccination-reaction-led causalities, simplifying compensation procedures, and introducing commercial insurance to increase compensation (Yue et al., 2014; Jia, 2016; Sun et al., 2017; Lai, 2018; Ye and Zhang, 2019).

Some scholars have addressed parental concerns and beliefs. They have suggested that the state should regulate the media to control online rumours (Yang, 2017; Dai and Zhu, 2018). Some have argued for adequate education of the public to mitigate personal risk perception (Ma, 2016; Yu, 2016; Zhuang and Wang, 2016; Wang et al., 2019), expanding the scope of free vaccines to reduce family expenses, and compulsory vaccination to tackle vaccination refusal (Wang et al., 2019).

\subsection{Implementing New Policies}

Some Chinese studies on vaccination hesitancy have put forth new policies to reduce the public's distrust in vaccination. Several studies have analysed the centralization of the segmented model to overcome the deficits in the segmented model. Yi and Liao (2013) indicated that the centralized model makes the Food and Drug Administration responsible for vaccine production, storage, circulation, and marketing, and the Health Department responsible for vaccine safety in medical institutions. Following this, Zhang (2017) stated that a strict top-down accountability system, public complaint mechanism, and specific punishment mechanisms were installed in 2015 to hold officials and manufacturers accountable. According to an analysis of Xue and Li (2019), in 2018, a centralized agency called the Market Supervision Administration, which was formed by merging the Food and Drug Administration, Industrial and Commercial Administration, and Health Administration, was established nationwide to prevent shirking of the responsibility for implementing vaccine safety regulations and to optimize the allocation of supervisory resources.

A few studies have analysed the "Draft of Vaccine Regulation Law" that was published by the state in 2018. This draft has sparked scholarly discussions in China. The "Law of Vaccine Regulation in China" was approved in the 11th meeting of the Standing Committee of the 13th National People's Congress on 29 June 2019, and will be implemented on 1 December 2019 (Ye and Zhang, 2019). Most scholars have assessed this new law rather positively. Both public policy experts and public health experts (Chinese Administrative Management Group, 2018; Qiao, 2018; Sun et al., 2018; Zhao, 2019) have argued that this law underlines the importance of adequate communication with the public. Additionally, according to an analysis of Lai (2018), the law prescribed a compensation system for 
vaccination victims who exhibited an abnormal vaccination response. Furthermore, Yue et al. (2019) argued that the state encourages commercial insurance providers to provide more compensation to victims and that it complements the public compensation system in an important way. The attempt made in the "Draft of Vaccine Regulation Law" to raise the quality standards of medical doctors was also received positively. Wang (2018) stated that the law will oblige doctors to inform parents about contraindications before vaccination and monitor post-vaccination effects, and in the study of Xiao (2017), it was argued that the medical institutions and doctors involved in vaccination should have specific qualifications.

Some Chinese scholars have clarified that although new policies were introduced to deal with vaccination hesitancy, the implementation of these policies was hampered. A journalist Li (2011) emphasized that it is difficult to hold medical doctors accountable in cases of malpractice because the criteria for malpractice are rather subjective. Although regulations state that doctors should bear certain responsibility for medical accidents, there are no criteria to define the severity of medical incidents or the degree of doctors' responsibility. Complementarily, a public policy expert Zhang (2014) stated that the system of accountability is very complex: Different bodies play different roles in the organization of accountability for medical incidents, and a lack of collaboration among these bodies causes tensions related to accountability. The local government, health bureau, court, social supervision committee, and medical ethics committee govern political accountability, administrative accountability, legal accountability, social accountability, and professional accountability, respectively. As a result, medical staff are confused as to whom they are accountable to and what they are accountable for (Wang, 2007).

Some sociologists (Han and Zhou, 2016; Qi and Cheng, 2015; Xiao, 2017) have argued that public distrust in vaccines has increased because of experts' subjective judgment and decision-making without incorporating public values and that to reduce this distrust, different stakeholders should be engaged in risk-assessment procedures. According to a journalist Song (2018), experts perform risk assessment within a rather narrow biological, chemical, and physical scope, and they are unable to incorporate novel viewpoints and considerations lying outside their framing of the problem. A CDC expert Zhang (2017) argued that engaging lay people who are unable to conceptualize the hazards in risk assessment will hamper expert risk assessments. Others disagree with this line of reasoning. Xiao (2017) has been argued that risk communication, instead of being a democratic dialogue, is dominated by experts who communicate top-down and regard the public as ignorant and irrational.

\section{Discussion}


This scoping review of studies related to the governance of vaccine hesitancy that were published in China between 2007 and September 2019 is the first of its kind to the best of our knowledge. The findings indicate that most studies on vaccine hesitancy have defined it as a problem related to vaccine incidents and vaccine safety. A smaller number of studies have defined it as a problem related to professional conduct, and a very small number have defined it as a problem related to parental beliefs or cognitions. Accordingly, most studies have assigned the responsibility for vaccine hesitancy to governance system factors, such as an inadequate supervision model and reduced participation and transparency. As solutions, they have proposed reformation of the supervision model, a strict top-down accountability system, and participatory turn in crisis response. A handful of studies have ascribed vaccination hesitancy to less responsive and less experienced doctors and relatively outdated technical equipment at the grassroots level. Professional training, resource investment, and regulation of doctors have been called for as solutions. Studies that focused on parental doubts and beliefs pointed to the influence of the media and inadequate public education. These studies proposed public outreach and communication as solutions. A few studies evaluated the new policies formulated to tackle this problem and pointed to diverse factors that hampered the effective implementation of these policies.

Vaccination hesitancy is a global phenomenon. However, in a systematic review conducted by Larson et al. (2014), it was concluded that the global determinants of vaccination hesitancy are country- and context-specific. In line with this, Dube et al. (2014) have demonstrated that immunization managers in different global regions have identified diverse locally relevant factors: religion, culture, socioeconomic situation, influential leaders and anti-vaccination lobbies, geographic barriers, personal risk perception and knowledge, introduction of a new vaccination, hesitancy among healthcare workers and among migrants, cost of vaccines, and role of healthcare professionals. Both studies have argued that understanding the contextual factors is important for developing adequate strategies to reduce vaccine hesitancy (Dube et al., 2014; Larson, 2014). This review underlines this insight by demonstrating the context-specific characteristics of vaccination hesitancy in China. Although many of the global determinants apply to the Chinese context, most studies have emphasized vaccine-related factors for hesitancy: Hesitance was mostly found to be associated with the safety of vaccines in the incidents that resulted in the death of children. Unsurprisingly, scholars have stressed the importance of reforming the model for supervising vaccine safety in China ( $\mathrm{Li}$ and Chen, 20111; Qiao and Wang, 2012; Jiang, 2014; Zhang, 2014; Zhou, 2014; Sun et al., 2015; Li et al., 2016), participation of stakeholders in the governance of safety (Xiao, 2017; Liu et al., 2017), more effective communication after several vaccine scandals have induced hesitancy (Huang, 2010; Wang and He, 2016; Liu et al., 2018), and raising the standards of medical doctors (Wen, 2011; Zhong et al., 2017). 
As such, the results of this review differ from the findings of another systematic review of vaccine hesitancy studies published between 2007 and 2012 (Larson et al., 2014). The previous review of vaccine hesitancy in the West Pacific Region, the region in which China is located, was related mainly to specific socioeconomic backgrounds and personal beliefs, as well as attitudes and knowledge pertaining to vaccination, not to vaccine safety (Larson et al., 2014). In our review, it appears that many academics and professionals in China consider vaccine hesitancy in relation to concerns about vaccine safety and its governance and supervision model. This difference in outcomes can possibly be explained by the fact that not many Chinese studies were included in the study of Dube et al. (2014), which, in turn, may be ascribed to the selected time period: Vaccine hesitancy in China was not studied extensively before 2012. It became a major problem only after a series of vaccine safety scandals and incidents in the last decade. This specific Chinese context helps us understand why a large number of studies by Chinese scholars have addressed vaccine hesitancy in relation to vaccine safety, the governance of vaccine safety, and the quality of healthcare professionals. Along similar lines, to reduce vaccine hesitancy and to increase public trust, most studies have pointed to improvements to the governance and supervision systems of vaccines in China. Few studies have dealt with parental beliefs and cognitions, but even most of these studies consider the beliefs of parents in the context of severe vaccination incidents.

Interestingly, our review revealed that the disciplinary backgrounds of scholars influence how they frame vaccination hesitancy. It appears that $54 \%$ of sociology and public policy experts, as well as $43 \%$ of public health experts tie vaccination hesitancy to vaccine safety and the governance of vaccine safety. A total of $41 \%$ of sociology and public policy experts, as well as $36 \%$ of journalists, mentioned inappropriate crisis management and a lack of participatory governance turns as the determinants of vaccine hesitancy. All the public health experts position vaccine hesitancy as a problem related to unprofessional conduct by healthcare professionals and parental beliefs (see Figure $3)$.

\section{Strengths and Limitations of Our Research}

The adoption of a scoping review methodology enabled us to present an overview of Chinese studies on vaccine hesitancy and vaccine hesitancy governance. Moreover, we identified a relationship between the expertise of scholars and the way they defined vaccine hesitancy as a problem, as well as the routes to reduce vaccine hesitancy. Our study findings should be considered in the light of certain limitations. First, we reviewed publications from 2007 to September 2019, and we may have overlooked important studies published before 2007. However, there are indications that vaccine hesitancy was not a public problem in China before 2007. By then, China had not experienced severe vaccine incidents, and most people readily accepted immunization after witnessing the impact of 
infectious diseases, such as SARS in 2003 and avian influenza in 2004 (Wang, 2007). The social memory of such epidemics intensified the public's sense of human vulnerability and generated in the public a fear of future infectious disease, which spurred the public to vaccinate their children. Second, the fact that we identified 20 articles only after bibliography screening displays that there is a high terminological diversity at play in issues of vaccine hesitancy in the Chinese databases (e.g., "vaccine circulation"). Over time, as this resource is used more and links between Western and Chinese debates are intensified, we expect higher terminological standardisation. Careful bibliographic screening help reveal this, but it is possible that a small number of studies nonetheless were not caught. Given the scoping nature of this review, associated methodological risks are limited, but for systematic reviews using these databases, this is a concern. Finally, we solely focused on scholarly arguments from four Chinese databases and excluded public opinions and grey literatures. To obtain additional insights into the specific Chinese context of vaccination hesitancy, studies in the future should glean data about the narratives of the public's concerns related to vaccine governance.

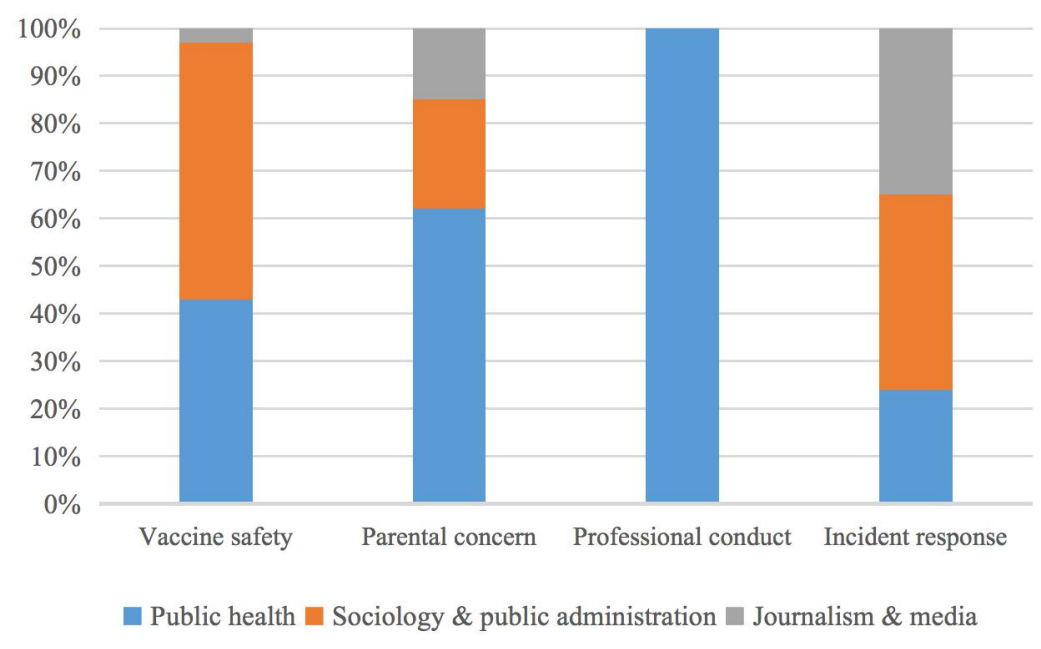

Figure 3. Relationship between categories of vaccine hesitancy and disciplinary backgrounds of scholars. Categories were assigned based upon problem articulation, solution proposals, and the allocation of responsibility (see Section 3.2 and Figure 2). Disciplinary background is drawn from author affiliations and personal information, also listed in Table A1.

\section{Conclusions}

Chinese scholars primarily defined vaccine hesitancy as a vaccine safety problem and only secondarily as an issue of professional medical conduct or parental beliefs. Consequently, they primarily locate accountability on the level of governance and only secondarily at the level of public 
communication and media. The analysis suggests that strategies to mitigate public distrust in vaccination programs should not only be limited to education of, communication with, and information dissemination to parents but should also emphasize vaccine safety control, social participation, and transparency in vaccination governance, as well as raising the standards of medical professionals engaged in vaccination. Globally, most strategies to deal with vaccination hesitancy focus on the users of vaccination. However, in the Chinese context, scholars stress the importance of improving the vaccination program itself.

\section{References}

An, L., Chen, W.and Sun, M., 2018. Analysis of vaccination status and influencing factors of varicella vaccine in children in Tianjin. Med. Anim. Control., 34, pp. 49-52.

Arksey, H. and O'Malley, L., 2005. Scoping studies: towards a methodological framework. International journal of social research methodology, 8(1), pp.19-32.

Cacere, M., 2018. Vaccine Scandal in China Crosses "Moral Bottom Line". 25-July. Available online: https://thevaccinereaction.org/ 2018/07/vaccine-scandal-in-china-crosses-moral-bottom-line/.

Cao, L., Wang, H. and Zheng, J., 2012. Investigation and Analysis of Vaccination Rate of Expanding National Immunization Program in China. Chin. J. Vaccines Immun., 5, pp. 419-424.

Chen, B., Zhang, J.M., Jiang, Z., Shao, J., Jiang, T., Wang, Z., Liu, K., Tang, S., Gu, H. and Jiang, J., 2015. Media and public reactions toward vaccination during the 'hepatitis $B$ vaccine crisis' in China. Vaccine, 33(15), pp.1780-1785.

Chen, T., 2017. Investigation on medical staff's knowledge on hepatitis B prevention. J. Tradit. Chin. Med. Manag. 12, pp. 107-108.

Chen, W., Gao, Z. and Li, Y., 2016. Investigation on the Impact of Illegal Vaccine Cases in Shandong on the Vaccination Attitudes and Behaviors of Children in Tianjin. China Public Health 32, pp. 881-884.

Cheng, M., Su, Z.and Lian, Q., 2014. Study on the effect of vaccination informing on the rate of vaccination adverse reactions. Lab. Med. Clin. 5, pp. 706-707.

Chinese Administrative Management Group., 2018. Balancing state supervision and market: Challenge and countermeasures of vaccine safety. Chin. Adm. Manag. 400, pp. 8-14.

Dai, W. and Zhu, Q., 2018. Research on Information Mechanism of Risk Amplification in Media Environment-Taking 2016 Shandong Vaccine Event as an Example. J. Southwest Univ. Natl. (Soc. Sci. Ed.)., 39, pp. 153-157.

Di, W., 2015. Company's Quality Risk Analysis and Control Strategy for Refrigerated Drug Transportation. Ph.D. Thesis, East China University of Science and Technology, Shanghai, China, 2015.

Dubé, E., Gagnon, D., Nickels, E., Jeram, S. and Schuster, M., 2014. Mapping vaccine hesitancy - Country-specific characteristics of a global phenomenon. Vaccine, 32(49), pp.6649-6654.

Geelen, E., van Vliet, H., de Hoogh, P. and Horstman, K., 2016. Taming the fear of voice: dilemmas in maintaining a high vaccination rate in the Netherlands. Social science \& medicine, 153, pp.12-19.

Guo, W., Wang, J.and Yu, X., 2018. Investigation on the willingness and influencing factors of EV71 vaccine for vaccination medical staff in Dezhou City. J. Prev. Med., 3, pp. 171-173.

Feng, B., 2014. Design and Implementation of Vaccine Cold Chain Supervision System. Master's Thesis, University of Electronic Science and Technology of China, Chengdu, China.

Han, J. and Zhou, W., 2016. System Optimization of Third-Party Participation in Social Stability Risk Assessment of Major Events. J. Chongqing Univ. Sci. Technol., 11, pp. 38-41. 
Hu, Y., 2014. Current Status and Improvement Countermeasures of Vaccine Supply and Supervision System in China. Chin. J. Drug Eval. 3, pp. 175-179.

Huang, Y., 2010. Analysis of risk management deficits in the Shangxi vaccine crisis. 2 Collect. Econ., 25, pp. 39

Jarrett, C., Wilson, R., O’Leary, M., Eckersberger, E. and Larson, H.J., 2015. Strategies for addressing vaccine hesitancy-A systematic review. Vaccine, 33(34), pp.4180-4190.

Jia, X., 2016. Problems and Countermeasures in the Relief System of Abuse Response Abnormality in China. Med. J. China., 29, pp. 50-53.

Jiang, Y., Yu, W. and Zhang, X., 2014. A telephone survey of public trust in vaccination after the hepatitis B vaccine incident in 2013. Chin. J. Vaccines Immun. 4, pp. 314-317.

Kunming CDC., 2018. Immunization Planning Experts Remind that do Not Hesitate to Inoculate. Kunming CDC blog. $25 \quad$ April. Available online: http://www. wanfangdata.com.cn/details/detail.do?_type=perio\&id=xdys201512015.

Kunming CDC., 2018. History of Chinese Vaccine Development_Past and Present of Vaccination. 25 June. Available online: http//www.sohu.com/a/229424002_99994855.

Lai, H., 2018. Research on Legal Issues of Vaccine Damage. Law Press: Beijing, China.

Lai, S., 2013. Accountability, Path Dependence and Disclosure: Local Government Behavior Research Based on 97 Public Crisis Cases. J. Public Adm., 10, pp. 18-27.

Larson, H.J., Jarrett, C., Eckersberger, E., Smith, D.M. and Paterson, P., 2014. Understanding vaccine hesitancy around vaccines and vaccination from a global perspective: a systematic review of published literature, 2007-2012. Vaccine, 32(19), pp.2150-2159.

Li, H., 2019. Vaccination: The Public Should Not Hesitate. China Science Newspaper. 29-April. Available online: http://www.qstheory.cn/science/2019-04/29/ c_1124431677.htm.

Li, T., 2011. Why Is it difficult for Doctors to Be Accused of "Medical Accidents"? China Young Online. 02-September. Available online: http://zqb.cyol.com/ html/2011-09/02/nw.D110000zgqnb_20110902_2-07.htm.

Li, T., Wang, H., Lu, Y., Li, Q., Chen, C., Wang, D., Li, M., Li, Y., Lu, J., Chen, Z. and Ma, Y., 2018. Willingness and influential factors of parents to vaccinate their children with novel inactivated enterovirus 71 vaccines in Guangzhou, China. Vaccine, 36(26), pp.3772-3778.

Li, W., Chen, W. and Zhang, J., 2016. Is it safe to vaccinate? Innov. Era, 5, pp. 13-14.

Li, Y. and Chen, B., 2011. Reflection and Restatement of the Second Kind of Vaccine Supervision Mechanism from the Perspective of Constitutionalism. Med. J. China 24, pp. 72-74.

Liu, D., Wu, W., Li, K., Xu, D., Ye, J., Li, L. and Wang, H., 2015. Surveillance of adverse events following immunization in China: Past, present, and future. Vaccine, 33(32), pp.4041-4046.

Liu, F., 2015. Discussion on the application of mother classroom in vaccination. Henan J. Prev. Med. 5, pp. $100-101$.

Liu, X., Hu, W. and Zhang, S., 2018. The trust degree of parents on the Shanxi vaccination progrma affected by the Shandong vaccine crisis in 2016. J. China Vaccine Immun. 24 (3), pp. 83-88.

Liu, X., Lin, R., Yang, C., Yu, S. and Zhang, B., 2017. Status, problems and countermeasures of vaccine safety supervision in China. China Public Health Manag. 2, pp. 50-53.

Lu, Y., 2018. Study on the Governance Issue of Vaccine Enterprises in China from the Perspective of Social Responsibility. Med. Law Sci., 10, pp. 55-60.

Ma, G., 2016. The Impact of the Health Belief Model on the Timely Vaccination of Migrant Children in the Community and Intervention Studies. Ph.D. Thesis, University of South China, Hengyang, China.

Ma, J., Zhou, L. and Zhou, L., 2015. The influence of negative information of hepatitis B vaccination on the vaccination trust of parents of urban and rural children in Ningxia. J. Ningxia Med. Univ., 37, pp. 1046-1049.

McLaughlin, K., 2016. Scandal clouds China's global vaccine ambitions. Science, 352, pp. 506. 
Meng, X. and Xu, L., 2012. Legal Mechanism, Institutional Investors and Corporate Governance-Based on Analysis of Chongqing Beer Hepatitis B Vaccine Project. Econ. Theory Bus. Manag. 32, pp. 96-103.

Ministry of Health: China's Immunization Program Vaccination Rate Continues to Remain Above 90\%. Available online: https://51jinke.com/news/5c739d48d42cbc28a9df0691 (accessed on 5 February 2019).

Peng, Z., Wang, D. and Yang, J., 2018. Current status of influenza vaccine application and policy promotion of vaccination. Chin. J. Epidemiol., 39, pp. 1045-1050.

Qi, C. and Cheng, L., 2015. Construction of the ethical accountability mechanism for medical staff. In Proceedings of the 9th Annual Conference of the Shandong Medical Ethics Society and the 2nd Session of the 4th Council, Shandong, China, 29 April.

Qian, X. and Wang, G., 2012. Analysis of China's Vaccine Supervision System Based on Executive Force Perspective. Chin. Pharm., 37, pp. 3474-3476.

Qiao, X., Wei, J.and Lu, D., 2018. Analysis of influencing factors of vaccination trust among grassroots medical staff. Int. J. Epidemiol. Infect., 45, pp. 436-440.

Ren, J., Wagner, A.L., Zheng, A., Sun, X., Boulton, M.L., Huang, Z. and Zikmund-Fisher, B.J., 2018. The demographics of vaccine hesitancy in Shanghai, China. PloS one, 13(12), pp. 1-12.

Sadaf, A., Richards, J.L., Glanz, J., Salmon, D.A. and Omer, S.B., 2013. A systematic review of interventions for reducing parental vaccine refusal and vaccine hesitancy. Vaccine, 31(40), pp.4293-4304.

Shi, L., 2017. The Impact of "Shandong Vaccine Incident" on the Attitudes and Behaviors of Parents of Children in Two Counties of Henan Province. China Health Educ. 33, pp. 255-257.

Song, J., 2015. Case Study of Kangtai Hepatitis B Vaccine Trust Crisis in 2013. J. Natl. Sch. Adm., 5, pp. 84-88.

Song, J., 2018. The Vaccine Safety Management Law Seeks for Advice: Severely Punish Illegal Behavior and Implement Four Most Strict Standards. Beijing Daily News. 12 November. Available online: https://baijiahao.baidu.com/s?id=1616889356040775516\&wfr= spider\&for=pc.

Song, J., 2018. The Compensation Mechanism Needs to Be Established. China Business Website. 27 June. Available online: http://www.cb.com.cn/zjssb/20180726/1248527.html.

Sui, X., 2014. Penglai City Took the Lead to Establish a Social Risk Assessment Mechanism. The Mass Newspaper. $\quad 02 \quad$ September, Available online: http: //www.dzwww.com/shandong/sdnews/201409/t20140902_10950508.htm.

Sun, L., Cong, Y. and Wang, Y., 2017. Public Attitude Analysis of Commercial Insurance Compensation Model for Abnormal Vaccination in Hebei Province. Chin. J. Vaccines Immun., 3, pp. 278-281.

Sun, L., Guo, J. and Li, J., 2018. Comparative analysis of factors affecting the knowledge and belief of divalent polio vaccine by vaccination doctors and parents. Med. Anim. Control, 8, pp. 715-721.

Sun, W.,2014. Child Plan Immunization. In Proceedings of the 31st Academic Conference of the Chinese Society of Chinese Medicine Pediatrics, Beijing, China, 14 January.

Sun, Y., Xu, L. and Li, S., 2015. Evaluation of the application effect of real-time monitoring system for vaccine cold chain temperature. Chin. J. Vaccines Immun. 6, pp. 675-679.

Tang, Z., 2018. Development and Preliminary Application of Children's Parents' Hesitation Questionnaire on Enterovirus 71 Inactivated Vaccine. Master's Thesis, Chinese Center for Disease Control and Prevention, Beijing, China.

Tricco, A.C., Lillie, E., Zarin, W., O'Brien, K.K., Colquhoun, H., Levac, D., Moher, D., Peters, M.D., Horsley, T., Weeks, L. and Hempel, S., 2018. PRISMA extension for scoping reviews (PRISMA-ScR): checklist and explanation. Annals of internal medicine, 169(7), pp.467-473.

Tong, X., 2019. Investigation on the awareness of residents' safety in Yangzhou City. China New Telecommun. 21, pp. 239-240.

Wagner, A.L., Boulton, M.L., Sun, X., Mukherjee, B., Huang, Z., Harmsen, I.A., Ren, J. and Zikmund-Fisher, B.J., 2017. Perceptions of measles, pneumonia, and meningitis vaccines among caregivers in Shanghai, China, and the health belief model: a cross-sectional study. BMC pediatrics, 17(1), p.143. 
Wang, B., 2018. Health Commission: Do a Follow-Up Observation and Counseling Service for Rabies Vaccinatees to Protect Their Legitimate Rights. China News. 07 August. Available online: http://www.xinhuanet.com/politics/2018-08/07/c_1123237162.htm.

Wang, C., Li, G. and Zhang, Y., 2019 Investigation on the status of vaccination among children aged 0-6 years in a county after the "Shandong Vaccine Incident". J. Pract. Prev. Med. 26, pp. 63-66.

Wang, P.and Yang, F., 2016. Discussion on Vaccine and Cold Chain Management Experience. China Health Ind., 13, pp. 187-189.

Wang, Y., 2007. Strengthening the public health management of medical institutions is the key to improving the quality and level of disease control in China. Chin. J. Med., 87, pp. 512-514.

Wang, Y., 2012. How to screen contraindications before vaccination. J. Med. Front., 2, pp. 311.

Wang, Y. and He, R., 2016. The Dilemma of Vaccine Circulation Industry Chain Management and Multi-Center Management System of Vaccine Safety. Enterp. Manag., 6, pp. 18-22.

Wang, Y., Sun, L. and Li, M., 2019. Analysis of influencing factors of vaccination hepatolysis in a medical community in Beijing. Chin. J. Reprod. Health., 30, pp. 149-153.

Wen, W., 2011. Discussion on Scientific Training and Assessment of Grassroots Vaccination Workers. Chin. J. Sch. Dr., 25, pp. 390-391.

Wu, Z., 2013. Current Situation and Management Countermeasures of Rural Children's Vaccination. Chin. J. Health Nutr., 6, pp. 85.

Xiang, F., 2012. Case analysis of medical disputes involving hepatitis B vaccine and BCG-coupled death. Zhejiang Prev. Med., 24, pp. 89.

Xiao, X., 2017. Dilemma of Public Participation in Risk Assessment. Decis. Consult. 5, pp. 81-85.

Xue, L. and Li, X., 2018. Deepening the Reform of Regulatory model and Promoting the Modernization of Market Supervision. China Adm. 398, pp. 23-31.

Yang, H., 2017. Research on the Drug Safety shifting from Administrative Supervision to Collaborative Governance in Shandong Vaccine Crisis. J. Tianjin Adm. Coll. 19, pp. 8-15.

Yang, M. and Ding, C., 2014. Discussion on the causes and countermeasures of adverse reactions of vaccination against DTP. Chin. J. Health Nutr., 7, pp. 4035.

Ye, L.and Zhang, X., 2019. Vaccine Management Law will be Enforced on 1 December 2019. Med. Soc., 7, pp. 66.

Yi, H. and Liao, T., 2013. Administrative accountability of food and drug-Taking the food and drug safety supervision system reform and function transformation as the entry point. Food Sci., 34, pp. 374-379.

Yu, F., 2016. Study on the influencing factors of immunization program immunization for migrant children. Chin. J. Health Nutr., 26, pp. 11-14.

Yu, W., Ji, S., Liu, J., Cong, B., Zhou, Y., Zhang, X., Cui, F. and Wang, H., 2016. Continuity monitoring and analysis of the impact of illegal vaccines in Shandong on the vaccination of children's parents. Chin. J. Vaccines Immun., 6, pp. 601-605.

Yu, W., Li, F. and Zhang, Z., 2014. Investigation and analysis of the trustworthiness of vaccination among parents of some provinces after the hepatitis B vaccine incident in 2013. Chin. J. Vaccines Immun., 3, pp. 233-236.

Yu, W., Liu, D., Zheng, J., Liu, Y., An, Z., Rodewald, L., Zhang, G., Su, Q., Li, K., Xu, D. and Wang, F., 2016. Loss of confidence in vaccines following media reports of infant deaths after hepatitis $\mathrm{B}$ vaccination in China. International journal of epidemiology, 45(2), pp.441-449.

Yuan, C. and Li, K., 2017. Analysis of Parents' Trust of Vaccination. J. Mudanjiang Med. Coll. 2, pp. 127-129.

Yuan, X., 2018. China's vaccine production scare. Lancet, 392, pp. 371.

Yue, C., Sun, X., Wei, N., Yu, W., Cui, F., Wang, H., Li, L., Zhang, L., Shi, G. and An, Z., 2016. Quick assessment of the influence of the Hepatitis B vaccine event on children's vaccination. Human vaccines \& immunotherapeutics, 12(10), pp.2611-2615. 
Yue, D., Chang, J., Hou, Z., Wu, Q. and Meng, Y., 2014. International vaccination anomaly response compensation mechanism for reference. China Health Econ., 1, pp. 93-96.

Zhang, D. and Chen, T., 2010. I know the truth about Shanxi vaccine. Communist Party Memb.,12, pp. 26.

Zhang, H., 2018. Innovative concepts and measures, exploring a new model of vaccination supervision. Chin. $J$. Health Superv., 1, pp. 15-18.

Zhang, K., 2017. The current problems and countermeasures of Drug Management in China. Rural Econ. Technol. 28, pp. 115-116.

Zhang, Y., 2014. Third Party Participation in Risk Assessment for Major Events: Significance, Dilemma and Countermeasures. Inn. Mong. Soc. Sci., 35, pp. 167-172.

Zhang, Y., 2017. Media reports that Chinese parents have decreased confidence in vaccination after hepatitis B vaccine causes infant death. Chin. J. Prev. Med. 51,pp. 518.

Zhang, Z., 2014. Research on Accountability of Medical Security Management in China. Chin. Med. Manag. Sci. 4, pp. 13-18.

Zhao, X., Zhou, L. and Yang, X., 2016. Investigation on the influence of hepatitis B vaccine incident on hepatitis $\mathrm{B}$ vaccination rate and cognitive attitude of parents in hepatitis B vaccine in Jinan City. Chin. Community J., 4, pp. 186-187.

Zhou, M., Qu, S., Zhao, L., Kong, N., Campy, K.S. and Wang, S., 2019. Trust collapse caused by the Changsheng vaccine crisis in China. Vaccine, 37(26), pp.3419-3425.

Zhou, W. and Li, H., 2014. Rent-seeking and Governance in Government Public Service Contract Outsourcing. Theor. Explor., 6, pp. 87-91.

Zhao, D., Li, X. and Lu, L., 2018. Investigation of training and information transmission effects after introduction of new vaccines into immunization programs. Cap. Public Health, 12, pp. 138-141.

Zhao, Z., 2019. Second trial of the draft vaccine management law: Further strengthen the management of vaccination and ensure the safety of vaccines. Chin. Peoples Congr., 477, pp. 20-21.

Zhong, X., Lu, Z. and Chen, X., 2017. Investigation of trust in the vaccination abnormal response monitoring by vaccination personnel and parent. China Public Health, 6, pp. 874-878.

Zhou, L., Yuan, H. and Wen, Y., 2017. Causes of refrigeration chain failure and improvement measures. Med. Equip., 30, pp. 97-98.

Zhou, Q., Liu, W. and Chen, L., 2018 The Impact of Shandong Illegal Vaccine Series on Vaccination Attitudes and Behaviors of Children in Shenzhen. Chin. J. Vaccines Immun., 2, pp. 11-14.

Zhuang, X. and Wang, R., 2016. Analysis of influencing factors of vaccination rate of children's immunization program in Tongnan County. J. Taishan Med. Coll. 37, pp. 1235-1237.

\section{Appendix A}

Table A1. Overview of selected research

\begin{tabular}{|c|c|c|}
\hline Article $(n=77)$ & Expertise & Perspective \\
\hline Chen T, 2017 & Public health & Professional conduct .. \\
\hline Liu, X., Hu W. \& Zhang S, 2018 & $\begin{array}{l}\text { Sociology and Public administration (Public } \\
\text { Administration). }\end{array}$ & Vaccine safety .. \\
\hline Zhang Y, 2017 & Public health (CDC). & Parental concern .. \\
\hline Tong X, 2019 & $\begin{array}{l}\text { Sociology and Public administration (Public } \\
\text { Administration). }\end{array}$ & Vaccine safety.. \\
\hline Zhou Q, Liu W, Chen L, 2018 & Public health . & Vaccine safety .. \\
\hline Peng Z, Wang D, Yang J, 2018 & Public health (Epidemiology). & Parental concern \\
\hline Wang \& He, 2016 & Sociology and Public administration (Sociology). & Vaccine safety .. \\
\hline Hu Y, 2014 & $\begin{array}{l}\text { Sociology and Public administration (Public } \\
\text { Administration). }\end{array}$ & Vaccine safety .. \\
\hline
\end{tabular}


Liu X, Lin R, Yang C, Yu S, Zhang B, 2017

CAMG, 2018

Li W, Chen W, Zhang J, 2016

Sun Y, Xu L, Li S, 2015

Chen W, Gao Z, Li Y, 2016

Di W, 2015

Shi L, 2017

Sun W, 2014

Yu, W, et al., 2014

Yuan \& Li, 2017

Zhang, K, 2017

Ma J, Zhou L, Zhou L, 2015

Meng \&Xu, 2012

Lu Y, 2018

Wang \& Yang, 2016

Qian \& Wang, 2012

Zhang $Y, 2014$

Zhou\& Li, 2014

Jiang Y, Yu W, Zhang X, 2014

Li H, 2019

Li \& Chen, 2011

Zhang $\mathrm{H}, 2018$

Han J, Zhou W, 2016

Lai S, 2013

Qi \&Cheng, 2015

Sui X, 2014

Xiao X, 2017

Song J, 2018

Song W. 2018

Huang, 2010

Zhao D, Li X, Lu L, 2018

Xiang F, 2012

Cheng M, Su Z, Lian Q, 2014

Liu F, 2014

Wang Y, 2012

Guo W, Wang J, Yu X, 2018

Qiao X, Wei Ji, Lu D, 2018

Zhao X, Zhou L, Yang X, 2016

An L, Chen W Sun M, 2018
Public health

Sociology and Public administration (Sociology) .

Journalism and Media .

Public health .

Public health (epidemiology).

Sociology and Public administration (Sociology).

Public health (CDC) .

Public health (Epidemiology).

Public health (CDC).

Public health .

Sociology and Public administration (Public Administration).

Public health (CDC).

Sociology and Public administration (Public

Administration).

Sociology and Public administration (Public Administration).

Public health (CDC) .

Sociology and Public administration (Public Administration).

Sociology and Public administration (Sociology).

Sociology and Public administration (Public Administration).

Public health (CDC).

Journalism and Media .

Sociology and Public administration (Public

Administration).

Sociology and Public administration (Public Administration).

Sociology and Public administration (Sociology).

Sociology and Public administration (Public

Administration).

Sociology and Public administration (Sociology).

Journalism and Media .

Sociology and Public administration (Sociology).

Journalism and Media .

Journalism and Media .

Sociology and Public administration (Public

Administration).

Public health .

Public health .

Public health .

Public health .

Public health .

Public health .

Public health (Epidemiology).

Public health .

Public health.
Vaccine safety ..

Vaccine safety ..

Vaccine safety ..

Incident response..

Vaccine safety ..

Vaccine safety ..

Vaccine safety ..

Parental concern

Vaccine safety ..

Vaccine safety ..

Parental concern

Vaccine safety..

Vaccine safety ..

Vaccine safety ..

Vaccine safety..

Vaccine safety ..

Vaccine safety ..

Vaccine safety..

Vaccine safety ..

Incident response.

Vaccine safety ..

Vaccine safety..

Incident response ..

Incident response.

Incident response..

Incident response.

Incident response.

Incident response.

Incident response.

Vaccine safety ..

Professional conduct .

Incident response ..

Professional conduct ..

Professional conduct .

Professional conduct ..

Professional conduct ..

Professional conduct ..

Professional conduct ..

Parental concern .. 
Tang Z, 2018

Dai \& Zhu, 2018

Yang $\mathrm{H}, 2017$

Cao L, Wang $\mathrm{H}$, and Zheng, 2012

Ma G, 2016

Yu F, 2016

Wang Y, Sun L, Li M, 2019

Zhuang X, Wang R, 2016

Huang S, 2015

Kunming CDC, 2018

Xue \& Li, 2018

Yu W, Ji S, Liu J, Cong B, Zhou Y,

Zhang X, Cui F, Wang H, 2016

Yi \& Liao, 2013

Zhang \& Chen, 2010

Yang \& Ding, 2014

Wu Z, 2013

Wang B, 2018

Feng B, 2014

Wen W, 2011

Zhong X, Lu Z, Chen X, 2017

Song J, 2015

Jia X, 2016

Lai H, 2018

Sun L, Cong Y, Wang Y, 2017

Yue D, Chang J, Hou Z, Wu Q, Meng Y, 2014

Ye and Zhang, 2019

Sun L, Guo J, Li J, 2018

Zhao Z, 2019

Li T, 2011

Zhang Z, 2014
Public health (Epidemiology).

Journalism and Media .

Sociology and Public administration (Sociology).

Public health (CDC) .

Sociology and Public administration (Sociology).

Public health (Epidemiology) .

Public health.

Public health (Epidemiology).

Journalism and Media .

Public health (CDC) .

Sociology and Public administration (Public Administration).

Public health (CDC).

Sociology and Public administration (Public Administration).

Public health (CDC) .

Public health .

Public health (CDC) .

Journalism and Media .

Public health .

Public health (CDC) .

Public health.

Sociology and Public administration (Public Administration).

Sociology and Public administration (Sociology).

Sociology and Public administration (Sociology).

Public health (CDC).

Public health .

Sociology and Public administration (Public Administration).

Public Health (CDC).

Sociology and Public administration (Public Administration).

Journalism and Media.

Sociology and Public administration (Public Administration).
Parental concern ..

Parental concern

Vaccine safety..

Parental concern ..

Parental concern ..

Parental concern .

Professional conduct ..

Parental concern..

Parental concern

Vaccine safety ..

Vaccine safety ..

Vaccine safety ..

Vaccine safety ..

Incident response ..

Professional conduct ..

Vaccine safety ..

Incident response.

Professional conduct ..

Vaccine safety ..

Professional conduct ..

Incident response ..

Incident response..

Parental concern..

Incident response.

Vaccine safety..

Vaccine safety..

Vaccine safety ..

Incident response.

Incident response.

Vaccine safety .. 
Chapter 5

Vaccine hesitancy in China: A qualitative study of stakeholders' perspectives 


\begin{abstract}
A series of vaccine incidents have stimulated vaccine hesitance in China over the last decade. Many scholars have studied the institutional management of these incidents but a qualitative study of stakeholders' perspectives on vaccine hesitancy in China is missing. To address this lacuna, we conducted in-depth interviews and collected online data to inquire into diverse stakeholders' narratives on vaccine hesitance. Our analysis shows different perspectives of medical experts, journalists, parents and self-defined vaccination victims on vaccination and vaccination hesitance. Medical experts generally consider vaccines, despite some flaws, as safe, and they consider most vaccine safety incidents related to coupling symptoms, not to vaccinations. Some parents agree with medical experts, but most do not trust vaccine safety and do not want to put their children at risk. Media professionals, online medical experts and doctors who do not need to align with the political goal of maintaining a high vaccination rate, are less positive about vaccination and consider vaccine hesitance a failure of expert-lay communication in China. Our analysis exhibits the tensions of medical expert and lay perspectives on vaccine hesitance, and suggests that vaccination experts 'see like a state', a finding consistent with other studies that have identified the over-politicisation of expert-lay communication in Chinese public discourse. Chinese parents need space to express their concerns so that vaccination programmes can attune to them.
\end{abstract}




\section{Introduction}

Vaccine hesitance, which is defined by the World Health Organisation (WHO) as a delay in acceptance or refusal to vaccinate despite the availability of vaccination services, has been reported in more than $90 \%$ of countries in the world (The Lancet Child and Adolescent Health, 2019). Although China maintains a high vaccination rate of more than $90 \%$ for Category 1 vaccines, ${ }^{6}$ vaccine hesitance exists in China as well. It has especially increased due to a series of 'vaccination crises' over the last decade (Cao et al., 218; Yang et al., 2020). In 2010, nearly 100 children suffered disability or death caused by adverse reactions to vaccinations in Shanxi province (Zhang, 2010). In 2013, eight babies died of adverse reactions after hepatitis vaccinations in southern China, and in 2016, many vaccines with unqualified cold storage entered the market in Shandong province, resulting in public anxiety(Chen et al., 2015). In 2018, Changchun Changsheng Biotechnology Co., Ltd. produced invalid DTP vaccines, harming many children (Chen et al., 2018). These incidents have all affected the public perception of vaccination safety in China. According to Liu (2016), reports on a series of vaccination-induced cases of disability and death have caused vaccination hesitance among parents. Some parents have turned to alternative imported vaccines, which they assume to be safer and more effective. Others have refused vaccination altogether.

Considering these incidents, it is not surprising that most studies of vaccine hesitance in China have focused on the governance of vaccine safety by institutional and regulatory bodies (Yang et al. 2020). Some Chinese scholars have assigned the responsibility for these safety incidents to the supervision system (Chen and Lai, 2018) or to the economic system of vaccine production (Chinese Administrative Management Group, 2018). Others have diagnosed vaccine hesitance as a problem of exaggerated media attention, arguing that the probability of abnormal reaction to vaccination is very small: less than 1\%o (Shanghai CDC, 2016; Wang et al., 2018). Some scholars also argued that imprecise media reporting stimulates parental risk perception and doubts of vaccine safety, lowering the rate of Category 2 vaccination (Liu et al., 2018). In addition, some have pointed to the role of professional medical conduct in stimulating vaccination hesitance and distrust (Yang et al., 2020). Doctors exhibit little regard for pre-vaccination screening and post-vaccination observation and are

\footnotetext{
6 The Chinese vaccination program distinguishes between Category 1 and Category 2 vaccines. Category 1 vaccines are provided for free for all children until 14 years, and the use of these vaccines is considered a social duty. Category 2 vaccines include vaccines to prevent diseases, such as the hepatitis B vaccine, polio vaccine, diphtheria-tetanus-pertussis (DTP) vaccine. Category 2 vaccines are optional vaccines and that have to be paid for by the parents. The vaccines in this category include, for instance, vaccines to prevent human papillomavirus (HPV), mumps, rubella, pneumococcus, and rotavirus (Cao et al., 2018).
} 
not responsive to questions during vaccination, causing dissatisfaction with vaccination services among parents (Cheng et al., 2014; Liu, 2015). Meanwhile, healthcare professionals vaccinate without considering individual circumstances and demands, thereby sparking vaccine distrust (Wang et al., 2014). Several studies noted that unresponsive doctors destroy public trust (Guo etal., 2018; Qiao et al., 2018), while others have argued that public distrust is the result of failed vaccination crisis management by both the state and experts (Yu et al., 2016; Zhou et al., 2019). However, according to Zhao et al.(2016), it is a lack of public participation and information transparency in vaccine risk assessment, as well as suspicions about experts conspiring with the state, that have eroded expert credibility.

While these studies critically analyse the issue of vaccine hesitance in China, a qualitative study of how diverse stakeholders - experts and lay - consider vaccine hesitance in China is missing. To address this lacuna, we conduct a qualitative study to understand how diverse stakeholders give meaning to vaccine hesitance in China: what do they consider the main problem and which kind of solutions do they think of. In the next section, we describe our methods of data-gathering and analysis. After the presentation of the results of the analysis, we discuss and reflect on the findings and on the difficulty of conducting a qualitative study on vaccine hesitance in China.

\section{Materials and Methods}

Scholars in qualitative research have argued that qualitative methods are important because of the variation and richness of data derived from detailed description, not the quantity of data in a category. According to Morse (1995) on the basis of data saturation comprehensive theories can be developed. In line with this, to do justice to a broad variety of narratives and perspectives, the first author conducted semi-open interviews with diverse stakeholders: two Center for Disease Control (CDC) experts, six vaccination doctors in hospitals, two online medical experts ${ }^{7}$, a consultant in vaccine manufacturing, four parents and two journalists (Millar and Tracey, 2009). The interviews took place in the cities of Shanghai, Wuhan and Xinyang from January to February 2019. Engaging parents in interviews proved challenging, which was likely due to political sensitivities. To do justice to lay perspectives, we also analysed detailed online narratives offered by three self-defined 'victims' of vaccination. The interviewees were purposefully selected: participants were approached because of their knowledge of and experiences with vaccination.

\footnotetext{
7 Online medical experts refer to the medical experts who provide medical consultation via the Mobile Health Application.
} 
The informal, snowballing selection of the participants was aligned to the specific Chinese context: selection started through informal, personal networks and continued through snowballing to include participants' colleagues. For all participants, participation was a sensitive matter. Experts and doctors were cautious to participate, as they believed that most Western investigators report Chinese vaccination incidents damningly, and they were concerned about being held accountable for eventual calumnious reports. When inviting people to participate, the first author underlined that the aim of the study was academic, not political or commercial, as state-salaried experts are not encouraged to involve themselves in interviews without state authorisation. Chinese citizens also generally distrust interviews conducted by strangers, and they are reluctant to openly express personal opinions about politics and policies, as they fear social reprisal and punishment by their leaders if they express ideas that deviate from official policies. Prior to the interviews, we obtained the oral informed consent of the research participants after sharing with them the research goals, methods, funding sources, expected outcomes, anticipated impacts, and the rights and responsibilities of the participants as well as establishing their anonymity. To facilitate interviewees telling their stories, the interview location selection was kept flexible, including tea bars, cafés, hospitals and interviewees' homes. During the interviews, the interviewees did not allow the interviews to be recorded, as they were worried about their privacy. The first author thus took intensive notes during and after the interviews, and after discussing the notes with the whole team, relevant sections were translated into English.

Restrained by states, there is less public discussion about vaccine hesitance on Chinese mainstream social media platforms such as Baidu, WeChat and Zhihu communities. Therefore, we collected stories of three self-defined victims of vaccination that were shared on the online Chinese forums of the Tianya community and Sina Weibo. The stories of self-defined victims of vaccination are interesting, as these accounts are less self-censored. On these online forums, one can speak relatively freely, as local governments believe that in an era of information explosion, online opinions with low click rates will not cause negative social effects, rendering governmental intervention unnecessary (Xu and Yang, 2014). These online comments tend to focus on the personal storytelling of vaccination-induced events, criticism of state performance and policy suggestions regarding the National Immunisation Programme (NIP). The lengths of these comments varied from one sentence up to 2,500 words. These comments were posted during the period of vaccine incidents between 2013 and 2018. We selected the stories of three self-claimed vaccination victims based on the time of post and the richness of the content. To protect the privacy and anonymity of the research participants, we assigned them codes: 'ID X' (see Table 1). ${ }^{8}$

\footnotetext{
${ }^{8}$ To ensure the quality of the data, the accuracy and consistency of translated interview notes from Chinese were verified by Liang Yu, associate professor in Tianjin University, China.
} 
Table 1.1. Participant characteristics and description of function

\begin{tabular}{lll}
\hline Interviewee ID & Gender & Description of function \\
\hline ID1 & Female & Expert in Shanghai CDC \\
ID2 & Female & Expert in Xinyang CDC \\
ID3 & Male & Clinician in Shanghai Tenth People's Hospital \\
ID4 & Male & Clinician in Wuhan Union Hospital Vaccination Clinic \\
ID5 & Female & Clinician in Xinyang Central Hospital \\
ID6 & Female & Clinician at Children's Health Clinic in Xinyang First People's Hospital \\
ID7 & Female & Clinician in Shanghai Hongkou Community Healthcare Service \\
ID8 & Male & Clinician in Xinyang Community Healthcare Service \\
ID9 & Male & Clinician in Wuhan Biotechnology Co., Ltd. \\
ID10 & Male & Online medical expert \\
ID11 & Male & Online medical expert \\
ID12 & Male & Journalist in Wuhan Jingchu media \\
ID13 & Female & Journalist in Xinyang Economic Daily media \\
ID14 & Female & Mom with a 5-year-old daughter \\
ID15 & Male & 50-year-old man, suffered from infantile paralysis in childhood \\
ID16 & Female & Mom with a 1-year-old son \\
ID17 & Male & Father with two children \\
\hline
\end{tabular}

Table 1. 2. Characteristics of online Informant and description of function

\begin{tabular}{llll}
\hline Informant ID & Gender & Function & UCL \\
\hline ID18 & Male & Self-defined victim: parent with a child who & http://bbs.tianya.cn/post-free-47 \\
& & suffered from disability after Polio vaccination & $08430-1$. shtml \\
ID19 & Female & Self-defined victim: parent with a daughter & http://bbs.tianya.cn/post-develo \\
& & who suffered epilepsy after rabies vaccination & $\mathrm{p}-2334312-1$. shtml \\
ID20 & Female & Self-defined victim: parent with a baby who & https://www.weibo.com/ttarticl \\
& & sufferred infantile spasms after DPT vaccination & e/p/show?id \\
& & & $=2309404181411853683814$ \\
\hline
\end{tabular}

To analyse the transcripts of the interviews and the online stories, we conducted a thematic analysis. Important themes that we identified were the safety of vaccines, the practical organisation of vaccination and responses to vaccine incidents. We identified more detailed sub-themes via deductive, iterative coding of the data: signing informed consent; combined and single vaccinations; antibody testing; vaccine incident investigation(s); information disclosure; and the diagnoses of side effects. Subsequently, exemplary data extracts were selected from the key sub-themes for inclusion as quotations (Guest et al., 2011). 


\section{Results}

The analysis of the perspectives and experiences of medical experts, clinicians, parents and journalists on vaccination are presented in three sections. First, we present the perspectives on vaccine safety. Second, we explore perspectives on the practical organisation of vaccination. Finally, we deal with the different perspectives on vaccination crisis responses.

\subsection{Perspectives on vaccine safety}

Notably, notwithstanding various vaccine safety incidents over the last few years, a CDC expert, two clinicians and two parents explained that there was no structural and fundamental safety issue with domestic vaccines. They claimed that the efficacy of vaccines had been undermined by illegal corporate production but that the safety of vaccines themselves was qualified (ID 1, 15, 16); strict electronic monitoring and a risk response system had been established by the state, so unqualified vaccines are now controlled promptly and vaccine safety incidents no longer occur.

The efficacy of vaccines produced by Changsheng decreased, but the safety of vaccines meets the standards, which means that it will not threaten citizens' lives. (ID 1)

During the Changsheng vaccine crisis, regulatory bodies uncovered falsifying data for the rabies vaccine and then controlled these problematic vaccines promptly. No faulty vaccine was consumed by citizens. (ID 6)

Additionally, re-vaccination campaigns were conducted by the state to ensure that antibodies were produced. (ID 3)

Along similar lines, the interviewed CDC expert, clinician pointed to bad reports in the media and unclear personal cognition of the hazards of epidemics and the benefits of vaccination, both of which raise the risk perceptions of parents:

Media reports included these casualties as a result of unsafe vaccine uptake and stimulated parental anxiety via rapid information dissemination online. (ID 2)

'People cannot give up eating for fear of choking'. They should not hesitate to vaccinate. An effective crisis response should be conducted to mitigate public disquiet. (ID 5)

Nonetheless, online medical experts established the opposite. They indicated that these less effective vaccines not only fail to prevent viral infections but also threaten children's lives (ID 10). According to them, most of the vaccines in the market are unqualified, which they attributed to illegal corporate production, unqualified cold storage, regulation deficits, and state-business collusion. One public 
expert acknowledged that Changsheng employed large tanks to produce vaccines instead of state-authorised canisters in an effort to maximise profits, generating great potential risks in vaccine safety (ID 11).

People may relax their vigilance and exercise less, as they believe that the antibodies produced after vaccination lead to decreased immunity, especially the invalid rabies vaccine, threatening people's lives. (ID 10)

Meanwhile, changes in the contents of culture containers produce new, unknown substances which current technologies fail to assess, increasing risks in vaccine safety. (ID 11)

In a similar way, journalists and an online medical experts noted that doctors are known to pile vaccines on easily accessible tables without cold storage at the county level to finish vaccination assignments quickly instead of caring about public health (ID 10,12, 13):

I saw the doctor throw vaccines on the table without cold storage and pile them randomly, which made me anxious about vaccine safety. During the vaccination, I kept asking: 'Is this kind of vaccine - please don't take it wrong - is it safe without cold storage?' (ID 13)

One parent argued that the regulatory bodies had adopted a random regulation model that only $5 \%$ of vaccines were selected for examination, resulting in large numbers of unqualified vaccines failing to be screened (ID 17). State-business collusion had also induced regulation deficits as well as unsafe vaccines, which one parent believed should be reported (ID 18). Vaccine manufacturers are keen to maintain private relationships with local officials; consequently, illegal corporate production occurs and regulatory capacity is eroded:

The vaccine regulatory system is strict in China, but why were falsified vaccine quality reports from the Chansheng company failed to be screened by the state? State-business collusion and bribery should be to blame. (ID 18)

An online medical expert indicated that $\mathrm{CDC}$ experts in public institutions are not involved in conversations related to negative information about vaccines, as they themselves undertake vaccination tasks, maintaining high vaccination coverage and scientific knowledge popularisation:

CDC experts are assigned with the responsibilities of immunization, epidemic-preventing and science popularisation regarding public health. When vaccination incidents occur, CDC experts are obliged to conduct crisis management and reassure the public. Additionally, CDC experts are able to release negative information concerning vaccination with the state permission, otherwise they will be accountable for damaging the reputation of the state (ID 10). 
To secure vaccine safety, both the online medical experts and the parents suggested reducing the economic incentives of manufacturers, expanding samples for inspection and restraining power-renting (ID 10, 11, 15):

More vaccines should be freely provided by the CDC, more than 5\% of vaccines should be selected for examination, and a strict administrative accountability mechanism should be conducted to impose punishments on manufacturers and officials. (ID 10)

In summary, $\mathrm{CDC}$ experts and clinicians claimed that vaccines were safe in China, as the strict regulation system plays a critical role in it. According to them, high personal risk perception should be attributed to negative reports by the media, and the narratives of online medical experts and the media are fundamentally opposed: online medical experts and journalists claimed that the invalid vaccines produced by manufacturers are fatal, putting citizens at risk. The parents, meanwhile, perceived deficits in the regulation system and call for reform.

\subsection{Practical organisation of vaccination}

Next to the vaccine safety issue, participants also present their ideas on the practical organisation of vaccination, which involves three topics: pre-vaccination informed consent forms, combined vaccinations and post-vaccination antibody tests.

\subsubsection{Signing pre-vaccination informed consent forms}

CDC experts argued that signing pre-vaccination informed consent forms facilitates the organisation of immunisation programmes, as it defines doctor-patient responsibility and reduces medical tensions, stimulating public understanding of vaccination expertise (ID 1,2).

More than $80 \%$ of doctor-patient tensions result from unclear responsibility-defining. Informed consent signing clearly allocates blame and mitigates tensions. (ID 2)

In similar ways, one parent considered disease-preventable vaccines, the types and cost of vaccines, contraindications (conditions in a recipient that increases the risk for a serious adverse reaction), adverse reactions and precautions to all be clearly elaborated in informed consent forms (ID 15). Clinicians argued that informed consent signing normalises vaccination procedures, increases doctors' communication awareness, promotes information transparency and stimulates public understanding of vaccination expertise (ID 4, 6, 7).

Doctors will cautiously screen children's health situations before vaccination, interact with the public about vaccination precautions, and record vaccination procedures. (ID 4) 
Nonetheless, informed consent signing was criticised by the online experts and three parents who considered it a strategy to deal with medical tensions and to exempt doctors from vaccination incidents. As CDCs undertake immunisation tasks, they are undoubtedly confronted with doctor-patient tensions caused by vaccination side effects while maintaining high vaccination coverage (ID 10). On the other hand, doctors claim 'no signing, no vaccination', forcing parents to give their informed consent before vaccination, which some interviewees believed ignores public benefits and is unjust (ID 16, 18). They also argued that, in practice, doctors are over-dependent on informed consent, stressing that parents read cautionary statements on the informed consent form without interacting with parents themselves (ID 19).

Because informed consent stresses parental duties but neglects to define doctors' responsibilities, I failed to hold doctors accountable after a side effect harmed my child. (ID 10)

Doctors ask parents to read vaccination knowledge on the informed consent form instead of informing them of precautions. This way, they do not have to interact with parents. (ID 19)

Parents suggested the following strategies to deal with public doubts on informed consent signing, including listing all the possible abnormal reactions and defining remedies and improving doctors' responsiveness (ID 19, 20):

All side reactions and remedies should be listed clearly, including the training that doctors have done to improve their social responsibility. (ID 20)

Most clinicians, CDC experts and vaccination doctors, and two parents noted that informed consent facilitates defining doctor-patient responsibility, reducing medical tensions, stimulating public education and improving doctors' responsiveness, while online medical experts criticised informed consent for exempting doctors from responsibility for incidents. Most of the parents also pointed out the injustice of compulsory informed consent and less interaction with doctors caused by over-dependence on informed consent.

\subsubsection{Single or combined shots}

Concerning vaccine choice, one CDC expert recommended the separation of Category 1 and Category 2 vaccinations to reduce their mutual influence and to better identify which vaccine causes side effects. 
Combined vaccination may interfere with producing different antibodies, increasing adverse effects. On the contrary, single shot is favourable to defining the responsibilities between CDC and the medical institution. (ID 2)

The CDC expert also pointed to the commercial nature of combined vaccines. Manufacturers and doctors exaggeratedly advertise their health benefits and vilify separate vaccinations to encourage combined shots (ID 1). Meanwhile, despite their high prices, some parents noted that combined vaccines are as effective as free single vaccines in terms of disease prevention (ID 16, 18).

Doctors recommend combined shots, as children benefit from [them]. These commercial combined shots are around 4,000¥, and I feel pressure to pay. I prefer the free single shot. 'Free' does not mean bad but is the best for my child. (ID 16)

One parent doubted the immature production technology and unknown risks of combined vaccines, as the practice has not been popularised nationwide by the state (ID 20). However, clinicians argued that combined shots were safe, were performed globally, and increased the efficiency of vaccination, as they involve fewer hospital visits, reducing the pain of injection and reducing vaccination-induced side effects (ID 3, 7, 12).

Diphtheria, Tetanus, acellular Pertussis, Inactivated Polio Vaccine (DTaP-IPV), adopting advanced technologies to quantitatively ration antigenic components, ensures solubility, physical compatibility and stability. (ID 3)

Four doses of DTaP-IPV injection with children instead of 12 doses of single shots greatly reduces the number of side effects and saves time in visiting the hospital. (ID 11)

As such, clinicians and journalists suggested that the state should provide policy support for combined vaccine innovation and clinical research and improve the combined vaccine industry infrastructure (ID 5, 6, 12, 13).

No manufacturers in China so far can produce the DTP vaccine, polio vaccine or DTaP-IPV vaccine. Therefore, the state should increase investment in technology innovation and promote the cooperation of manufacturers and research institutes to overcome technical bottlenecks and stimulate industrial upgrading. (ID 6)

Many clinicians and parents essentially took this view, considering combined shots safe and convenient. CDC experts, on the other hand, proposed single shots to better define the responsibilities of the CDC and the hospital for vaccination-induced side effects, and they noted the commercial purposes of combined shots. Similarly, a few parents were concerned about the potential risks of combined vaccines. 


\subsubsection{Post-vaccination antibody tests}

CDC experts and Clinicians argued that not everyone needed a post-vaccination antibody test. As the NIP adopts the 'herd immunity' strategy, a form of indirect protection from disease that occurs when most of a population has become immune to an infection, thereby providing a measure of protection for individuals without antibodies produced after immunisation (ID 1, 2, 5, 8).

Herd immunity greatly increases the efficiency and reduces the costs of vaccination programmes. As long as everyone can be vaccinated in a timely manner, individuals vulnerable to infection without antibodies will be protected, and the disease will inevitably be eliminated (ID 5).

Additionally, CDC expert noticed that the antibody reagents were sometimes insensitive, causing inaccurate antibody tests. For instance, fewer antibodies are generated in blood circulation, which cannot be detected by current technology, but this does not entail that children do not have the antibodies (ID 2). Instead, the observation method could be a method to assess antibody presence (ID $16)$.

Bacteria generated by uptake of live bacterial vaccines need to grow and multiply in individual bodies to activate the immune system, and there will be a skin reaction within 2-3 months, which indicates generated antibodies. (ID 16)

However, journalists and online medical experts suggested antibody tests need to be designed through technology, as personal experience is less credible and the success rate of vaccination is not perfect. Children should be tested for reassurance, they said, rather than blindly re-vaccinated (ID 10-13).

During the Changsheng invalid vaccine incident in 2018, several local governments conducted re-vaccination campaigns, but they only increased the chances of side effects. I suggest testing antibodies first. (ID 12).

As such, parents have developed two schemes to test for antibodies via technology. One group of parents suggested visiting antibody test agencies in Hong Kong, considering its good antibody test infrastructure and convenient transportation (ID 17). Another group of parents called for developing antibody test infrastructures on the mainland (ID 14, 15).

I took planes to go Hong Kong with my child and finish antibody testing on the same day. Then I received the report quickly. (ID 17)

While the cost of antibody tests in Hong Kong is expensive, antibody tests relate to public health. The state should build laboratories to provide test services. (ID 15) 
In summary, CDC experts argued for no antibody testing, considering its insensitivity and their adoption of the herd immunity strategy. A few parents suggested assessing antibodies through observation. Journalists and online medical experts opposed both these suggestions and argued for antibody tests for reassurance. Consistent with this advice, many parents proposed doing antibody tests in Hong Kong and called for developing antibody test infrastructure in mainland China as well.

\subsection{Incident response}

In this section, Chinese stakeholders present their arguments on adverse vaccination-induced events, involving vaccine incident investigations, information transparency and diagnosing adverse effects.

\subsubsection{Vaccine incident investigations}

When adverse vaccination-induced events occur, CDC experts are authorised to conduct risk assessments to ascertain causality and responsibility, but perspectives on this procedure also differ. According to the interviewed CDC experts, to ensure justice during the procedures of data collection and risk assessment, strict norms for data collection (ID 4, 5) and the entry qualifications of experts for risk assessment are necessary (ID 1,2).

There is at least one clinical expert participating in data collection to obtain detailed information about children and doctors. (ID 4)

Experts eligible for risk assessment should have professional knowledge and extensive clinical experience and should be selected randomly from expert databases. Those who keep relations with victims and vaccinators should be excluded. (ID 2)

However, these standards of risk assessment were questioned by many parents. Despite CDC expert recusal regulated by immunisation laws, in practice, local CDC experts often involve themselves in risk assessment and steer decision-making (ID 14, 19). Meanwhile, there is a lack of specific technical standards for risk assessment, leading to different diagnoses for incidents in different regions (ID 18).

The CDC is not only the athlete but also the referee in the risk assessment, as risk assessment experts keep close ties with local CDCs and prioritise their interests (ID 19).

Experts make subjective decisions based on partial medical records and personal experience. (ID 18)

One clinician countered that expert risk assessment was just, as there is no absolutely reliable technology to ascertain causality; the best technicians make the best diagnoses for vaccine incidents 
(ID 6). To mitigate these disputes between experts and the lay public, the latter should be encouraged to participate in risk assessments to judge, discuss, debate and compromise (ID 10). Besides, considering that lay experience might be marginalised in risk assessment, as experts take the experience of the public for granted as a constraint, one journalist and online medical experts argued that the lay public could delegate expert agents and third-party institutions to assess risk to maintain their benefits and values (ID 10-13).

Parents know children's health situations and witness vaccination procedures. Their involvement in risk assessment will contribute to better judgement, negotiation, information transparency and trust. (ID 11)

In summary, $\mathrm{CDC}$ experts and clinicians valued the risk assessment procedure just as they valued strict norms for data collection and entry qualifications of risk assessment experts, while many parents questioned the procedure's justice and pointed to CDCs steering risk assessments and the subjective diagnoses of experts. Journalists and online medical experts proposed public engagement to mitigate this distrust.

\subsubsection{Information disclosure}

Information disclosure relates to scientific risk assessment and blame allocation. Interviewed CDC experts indicated that the state had established specific norms for information transparency and regularly evaluated the extent of information disclosure at the local level (ID 1,2).

Laws have defined specific standards for information disclosure. To stimulate transparency, the state conducts rigorous annual evaluations at the local level. (ID 2)

Different from the routine period, clinicians and one parent argued for the rationality of maintaining positive, limited information disclosure during crises to mitigate public panic, as they believed that absolute transparency would stimulate distrust and increase supervision difficulty (ID 7, 8, 9, 16).

During the hepatitis B vaccine [incident] in 2013, the government kept the investigation process transparent, which in turn fed public fear. (ID 7)

However, journalists and online medical experts argued that accountability required information transparency. Limited information disclosure spurs local officials into suppressing information dissemination and encourages experts to privatise data, resulting in less media concern and a general failure of public accountability (ID 10-14, 17, 18). As response, they proposed solutions such as traceability systems and live streaming to monitor vaccine incident investigations (ID 6, 10).

Public officials will not release unfavourable information, aiming to shirk responsibility. 
Experts will claim 'coupling symptoms' while keeping evaluation procedures, techniques and standards opaque. (ID 17)

The traceability mechanism records details of crisis management to keep information relevant to victims, vaccination, diagnosis, data collection and risk assessment. Live streaming can be adopted to ensure the procedure's transparency. (ID10)

In summary, $\mathrm{CDC}$ experts and clinicians argued, on the one hand, that established standards were capable of keeping information transparent at the local level. They also stressed limited information disclosure during crises to reassure the public. Journalists and online medical experts, on the other, countered that accountability requires information transparency and that information asymmetry encourages buck-passing. As response, they called for traceability systems and live streaming to maintain procedure transparency.

\subsubsection{Diagnosing adverse effects: 'coupling' or 'malpractice'}

One of the themes in the interviews was diagnosing adverse effects. The interviewed CDC experts argued that most of the abnormal reactions to vaccination were coupling symptoms related to children's health situations and parent knowledge of vaccination (ID 1,2), not to vaccination, as doctors vaccinate in a standard fashion (ID 7).

'Coupling' is a personal health problem in which a disease is incubated before vaccination and arises even without vaccination. Parents should be blamed, as they do not read the contraindications precisely, do not provide children's health situations and do not follow guidelines. (ID 2)

These vaccines are safe. The qualifications of doctors, information records of vaccination, and equipment meet the standards. (ID 7)

The online medical experts proposed an inversion principle of the burden of proof, namely, that doctors should provide sufficient warrants to identify whether their actions amount medical malpractice, as parents lack the expertise to conceptualise risks and prove doctors wrong (ID 10, 11).

Doctors who are unable to provide logical evidences to substantiate their vaccination behaviours should be accountable for vaccine incidents. (ID 11)

Some parents argued that most children were diagnosed with coupling symptoms without persuasive evidence (ID 14). One self-defined victim accused coupling as a tool for experts to pass the buck, as her child had no allergic history or contraindications (ID 18). 
There were seventeen vaccine cases all diagnosed as coupling in 2017, not related to vaccination, causing public distrust. (ID 14)

Clinicians recognised disputes over coupling diagnoses but indicated difficulty in defining responsibility. According to some, the state should improve the compensation standards for vaccination-induced side effects (ID 5, 6, 9).

The complexity of personal physiques, the professionalism of vaccination and environmental vulnerability all make it difficult to allocate blame. The state should provide more financial relief instead of responsibility-defining. (ID 6)

Along similar lines, parents pointed to issues in the current compensation system and called for updating it to improve compensation amounts, simplify the application procedures and create commercial insurance mechanisms as complements (ID 15, 16).

Terms for applying compensation are extremely harsh, and victims get less compensation [as a result]. Financial relief should be improved, including for coupling and general reaction, procedures [should be simplified], and commercial insurance [should be introduced]. (ID 16)

In summary, $\mathrm{CDC}$ expert tended to diagnose vaccine incidents as coupling symptoms unrelated to vaccination, while parents opposed coupling diagnoses as unpersuasive and argued that they were tools for doctors to pass the buck. The inversion of the evidentiary burden proposed by online medical experts is a possible solution, but considering the difficulty of responsibility-defining, clinicians and parents suggested a compensation system update instead.

\section{Discussion}

This qualitative study indicates that medical experts, journalists and lay people have different perspectives on vaccination hesitance in China. Most interviewed CDC experts and clinicians and two parents considered that the strict regulation has enabled vaccines safe for the general public despite a few flaws in some regional areas. They favoured the national immunisation program (NIP) based on how it was logistically organised: signing informed consent, single shots of vaccines and the absence of antibody tests. They also justified past vaccine crisis responses as transparent and rational. The rest of parents, the online medical experts and all self-claimed vaccination victims presented different views. They considered vaccines unsafe and risky for their children as vaccination doctors inappropriately kept vaccines in cold storage and some manufacturers were known to have produced invalid vaccines. They also criticised compulsory signing of informed consent forms as a way to exempt doctors from responsibility for vaccination incidents. Contrary to the CDC experts and clinicians, these parents also preferred combined shots of vaccines and performing antibody tests on 
their children. They were not convinced by the responses of experts and public health bodies to vaccination incidents and called for more transparency to restrain buck-passing of risk assessment experts and public engagement to attune to public benefits in crisis responses. Journalists and online medical experts mentioned the same risks in vaccine safety, vaccination organisations and crisis responses as these parents, and they considered parental mistrust in the NIP a result of a failure of science popularisation in China.

The analysis indicates that, while medical doctors and parents do not present themselves as homogeneous groups, the perspectives of expert and laypersons on vaccine hesitancy in China differ. To maintain a high vaccination rate, medical experts stress the safety of vaccines and the scientific organisation of immunization, and legitimatise incident response. Vaccination hesitance is ascribed to negative media reports about vaccination. In line with this, medical experts propose science popularisation to mitigate parental vaccine hesitance. Medical experts articulate a 'deficit-model" of communication, that considers expert knowledge as a standard and lay perspectives as irrational and lacking adequate knowledge (Durant et al., 1992; Gross, 1994). The deficit model assumes that expert knowledge should be popularized for lay people, to stimulate rational choices. However, according to several scholars, this model reproduces instead of reduces public distrust in experts (Hobson, 2003; Brossard and Lewenstein, 2009; Geelen et al., 2016; Goldenberg, 2016).

To mitigate public distrust in experts in China, in 2006 the term 'science communication' was introduced to replace 'science popularisation' to emphasise the interaction between scientists and citizens in China instead of top-down communication (Chen, 2009). The massive science popularisation campaigns that were embedded in political rhetoric, were conducted to fight superstition, improve the low health literacy of Chinese citizens and serve 'the communist ideology', and the notion of science communication aims to depart from that history. Nonetheless, according to Chen et al.(2009), in practice, science communication in China remains a unidirectional transmission of knowledge from scientific experts to the public. China has put scientific expertise in an authoritative position since reform and opening-up policy in China in late 1970s, and governments invite 'policy-compatible' scientists as their spokespeople to 'speak truth to power' (Zhang, 2015). The close interaction between the state and science may put citizens at risk of harm (Goldenberg, 2009). One can also observe these characteristics of science communication with respect to vaccination hesitance. Symmetrical communication about vaccination incidents is difficult (Fang, 2013). The Chinese state, out of fear of erosion of its authority, tends to prevent citizens from engaging in discussion of the vaccination programme. State-allied experts are reluctant to get involved in open debates on the NIP, as they worry about loss of credibility caused by societal scepticism (Jia and Liu, 2014). 
Deficits in bilateral communication and public engagement about the NIP have stimulated the development of informal forums where experts and laypeople initiated discussions over vaccination hesitance on the Internet, such as the Sina Weibo, Zhihu and Tianya communities, with less political restraint. According to Liang et al. (2019), some public experts and journalists have discussed social justice issues in the NIP on these forums, such as adverse vaccination-induced events, potentially unsafe vaccines and parent hesitance. Independent experts and journalists give voice to the laity, which expands the influence of independent experts and journalists. This informal practice is considered to be an instrument to compensate for deficiencies in public discourse in the formal system of quasi-authoritarian state (Zvonareva et al., 2018). Our analysis shows that the construction of private, informal forums to discuss issues like vaccination implies that public engagement is not entirely absent in the largely authoritarian regime of China.

The coronavirus disease 2019 (COVID-19) pandemic in China might increase vaccine acceptance and mitigate vaccine hesitance among parents temporarily, as SARS did in 2003 (Gjorgjieva, 2005; Piltch-Loeb, and Diclemente, 2020). A new study of vaccination hesitance in the context of COVID-19 is required to explore whether we find a similar diversity of perspectives, whether the history of vaccination scandals is still resonating in the context of COVID-19, or whether there is more consensus about vaccination. Despite the changing context of vaccination issues, our study suggests a need for more open dialogues between experts and parents about their experiences with and insights into vaccination and this need may be even stronger in the context of COVID-19. Although the current Chinese political system, especially the close ties between the state and experts, makes such dialogues difficult, decision-makers and experts have realised the importance of a more open communication about public health crisis in mitigating public distrust during the COVID-19 control in China. The initial response of Wuhan state to minimize information transparency when the first cases of COVID-19 were identified, turned out to increase public distrust in public health instead of increasing public trust, and this stimulated more openness (Xue, 2020). Increasingly, medical experts have developed communication and interaction with the public about the management of COVID-19 via various channels: they communicated on social media platforms and via media interviews, and became actively involved in debates about controversial topics. Hence, future studies should explore in depth how expert-lay communication about vaccination hesitancy in China develops in China in the context of COVID-19.

\section{Limitations of this research}

This is the first qualitative study that provides in-depth understanding of stakeholder perspectives on vaccine hesitancy in China. The results of this qualitative study must be considered against the background of its limitations. First, the sample is diverse, but still small, and new studies are required 
to add to these insights. Second, to understand multiple stakeholders' perspectives on vaccine hesitance, we also included rich and detailed online vaccination stories of three parents. As these parents consider their children as victims of vaccination, these stories are even more critical than others. Third, this study focused on examining vaccine hesitancy in urban areas. However, according to Wagner et al. (2019), the determinants of vaccine hesitance varied by regions. Parental vaccine hesitance was rising in the rural areas of China as well, and the rates and determinants of vaccine hesitancy differed in the context of cities and in rural areas (Xiao et al., 2015; Zhu et al., 2018). To get insight into the vaccine hesitancy in the various contexts of China, future studies should glean empirical evidence of vaccine hesitance in rural areas.

\section{Conclusions}

A large gap exists between medical expert and lay perspectives on vaccination. Vaccination experts align themselves with the political aim of raising vaccination rates through improvement of public scientific literacy. ${ }^{9}$ In contrast, the public displays distrust towards experts who are not sensitive to the doubts and criticisms of parents after severe vaccination incidents and simply repeat the state-endorsed view that the NIP is safe. Our analysis indicates that expert-lay relationships in China would benefit from less state influence on vaccination programs, as that would provide space for a open and sincere dialogue between experts and lay people that enables parents to express their concerns about vaccination programmes and experts to respond to those concerns in a fair way.

\section{References}

Brossard, D. and Lewenstein, B.V., 2009. A critical appraisal of models of public understanding of science: Using practice to inform theory. In Kahlor, L. and Stout, P. ed. Communicating science. Routledge. pp.25-53.

Cao, L., Zheng, J., Cao, L., Cui, J. and Xiao, Q., 2018. Evaluation of the impact of Shandong illegal vaccine sales incident on immunizations in China. Human vaccines \& immunotherapeutics, 14(7), pp.1672-1678.

Chen, B., Zhang, J.M., Jiang. Z., Shao. J., Jiang, T., Wang, Z., Liu, K., Tang, S., Gu, H. and Jiang, J., 2015. Media and public reactions toward vaccination during the 'hepatitis $\mathrm{B}$ vaccine crisis' in China. Vaccine. 33(15), pp.1780-5.

Chen, F.; Shi, Y.; Xu, F., 2009. An analysis of the Public Scientific Literacy study in China. Public Understanding of Science, 18(5), pp. 607-616.

Chen, G. and Lai, R., 2018. China's Vaccine Scandal 2018: Pharmaceutical Companies Facing Heightened Regulatory Risks. East Asian Institute, National University of Singapore.

Cheng, M.; Su, Z.; Lian, Q., 2014. Study on the effffect of vaccination informing on the rate of vaccination adverse reactions. Lab. Med. Clin. 5, pp. 706-707.

Chinese Administrative Management Group., 2018. Balancing state supervision and market: challenge and countermeasures of vaccine safety. Chinese Administrative Management, 400(10), pp. 8-14.

\footnotetext{
${ }^{9}$ As such, they, alongside Chinese government, 'see like a state' and focus on formal standardized metrics over reciprocal engagement (Scott, 1998).
} 
Durant, J., Evans, G. and Thomas, G., 1992. Public understanding of science in Britain: the role of medicine in the popular representation of science. Public Understanding of science, 1(2), pp. 161-182.

Fang, X., 2013. Local people's understanding of risk from civil nuclear power in the Chinese context. Public Understanding of Science, 23 (3), pp. 283-298.

Geelen, E., van Vliet, H., de Hoogh, P. and Horstman, K., 2016. Taming the fear of voice: dilemmas in maintaining a high vaccination rate in the Netherlands. Social science \& medicine, 153, pp.12-19.

Gjorgjieva, J., Smith, K., Chowell, G., Sánchez, F., Snyder, J. and Castillo-Chavez, C., 2005. The role of vaccination in the control of SARS. Math. Biosci. Eng., 2(4), pp. 753-769.

Goldenberg, M.J., 2016. Public misunderstanding of science? Reframing the problem of vaccine hesitancy. Perspectives on Science, 24(5), pp.552-581.

Gross, A.G., 1994. The roles of rhetoric in the public understanding of science. Public understanding of science, 3(1), pp. 3-24.

Guest G, MacQueen, K.M. and Namey, E.E., 2011. Applied thematic analysis. Sage Publications.

Guo, W.; Wang, J.; Yu, X., 2018. Investigation on the willingness and inflfluencing factors of EV71 vaccine for vaccination medical staffff in Dezhou City. J. Prev. Med., 3, pp. 171-173.

Hobson-West, P., 2003. Understanding vaccination resistance: moving beyond risk. Health, risk \& society, 5(3), pp. 273-283.

Jia, H. and Liu, L., 2014. Unbalanced progress: The hard road from science popularisation to public engagement with science in China. Public Understanding of Science, 23(1), pp. 32-37.

Liang, J., Liu, X. and Zhang, W., 2019. Scientists vs laypeople: How genetically modified food is discussed on a Chinese Q\&A website. Public Understanding of Science, 28(8), pp. 991-1004.

Liu, F., 2015. Discussion on the application of mother classroom in vaccination. Henan J. Prev. Med., 5, pp. 100-101.

Liu, S., 2016. Improving vaccine supervision system in China after Shangdong vaccine crisis. Modern economic information, 14(3), pp. 12-14.

Liu, X., Hu, W. and Zhang, S., 2018. The trust degree of parents on the Shanxi vaccination progrma affected by the Shandong vaccine crisis in 2016. Journal of China vaccine and immunization, 24, pp. 83-88.

Millar, R. and Tracey, A., 2009. The interview approach. In: Hargie, O.E. and Tourish, D.E., ed. 2009. Auditing organizational communication: A handbook of research, theory and practice. Routledge/Taylor \& Francis Group, pp. 1-26.

Morse, J.M.,1995. The significance of saturation. Qualitative Health Research 5(2), pp. 147-149.

Penders, B., 2017. Vaccines, science and trust. Nature microbiology, 2(6), pp. 1.

Piltch-Loeb, R.; Diclemente, R., 2020. The vaccine uptake continuum: Applying social science theory to shift vaccine hesitancy. Vaccines, 8(1), pp. 76.

Qiao, X., Wei, J. and Lu, D., 2018. Analysis of influencing factors of vaccination. International Journal of Epidemiology and Infectiology, 45(6), pp. 436-440.

Scott, J.C., 1998. Seeing like a state: How certain schemes to improve the human condition have failed. Yale University Press.

Shanghai CDC., 2016. Vaccine abnormal response rate is less than 1\%. China Youth network. 3 March. Available at: http://www.sohu.com/a/65119558_119038

The Lancet Child \& Adolescent Health., 2019. Vaccine hesitancy: a generation at risk. The lancet, 5, pp. 281.

Wang, L.D.L.; Wendy, W.T.L.; Joseph, T.W.; Liao, Q.; Richard, F., 2014 Chinese immigrant parents' vaccination decision making for children: a qualitative analysis. BMC public health, 14(1), pp. 1-13.

Wang, X., Zhou, X., Leesa, L. and Mantwill, S., 2018. The effect of vaccine literacy on parental trust and intention to vaccinate after a major vaccine scandal. Journal of health communication, 23(5), pp.413-421.

Wagner, A.L.; Masters, N.B.; Domek, G.J.; Mathew, J.L.; Sun, X.; Asturias, E.J.; Ren, J.; Huang, Z.; Contreras-Roldan, I.L.; Gebremeskel, B.; Boulton. M.L., 2019. Comparisons of vaccine hesitancy across five low-and middle-income countries. Vaccines, 7(4), pp. 155. 
Xiao, Z., Wang, C. and Wang, Yan., 2015. Qualitative research on vaccination knowledge, attitude and behavior of child guardians in rural areas. Chinese Primary Health Care, 29(10), pp. 73-75.

$\mathrm{Xu}, \mathrm{W}$. and Yang, M., 2014. Crisis and Turnaround of Government Supervision in the Fragmentation of New Media Information. Modern Information, 6, pp. 50-53 + 57 .

Xue, L., 2020. The role of science in public decision-making: focusing on the risk research and judgment mechanism in public health events. Studies in Science of Science, 38(3), pp. 385-387.

Yang, R., Penders, B. and Horstman, K., 2020. Addressing Vaccine Hesitancy in China: A Scoping Review of Chinese Scholarship. Vaccines, 8(1), p.2.

Yu, W., Liu, D., Zheng, J., Liu, Y., An, Z., Rodewald, L., Zhang, G., Su, Q., Li, K., Xu, D. and Wang, F., 2016. Loss of confidence in vaccines following media reports of infant deaths after hepatitis $\mathrm{B}$ vaccination in China. International journal of epidemiology, 45(2), pp.441-449.

Zhang, J.Y., 2015. The 'credibility paradox'in China's science communication: Views from scientific practitioners. Public Understanding of Science, 24(8), pp.913-927.

Zhang, S., 2010. Experience of the Shanxi vaccine incident. China Public Health Management, 6, pp. 18-19.

Zhao, X., Zhou, L. and Yang, X., 2016. Investigation on the influence of hepatitis B vaccine incident on hepatitis $\mathrm{B}$ vaccination rate and cognitive attitude of parents in hepatitis B vaccine in Jinan City. China Community Journal, 4, pp. 186-187.

Zhou, M., Qu, S., Zhao, L., Kong, N., Campy, K.S. and Wang, S., 2019. Trust collapse caused by the Changsheng vaccine crisis in China. Vaccine, 37(26), pp. 3419-3425.

Zhu, S., Chang, J. and Ji, W., 2018. Investigation on Parents' Attitudes and Hesitation to Child Vaccination in Xi'an. Chinese Pharmaceutical Affairs, 32(001), pp. 136-141.

Zvonareva, O., Popova, E. and Horstman, K. 2018. Health, Technologies, and Politics in Post-Soviet Settings. Springer. 


\section{Chapter 6}

Conclusion: Public accountability of food and vaccine safety in China: How institutional efficiency, social responsiveness and democracy meet 


\section{Construction of public accountability of food and vaccine safety in China}

In this thesis, informed by theoretical discussions about public accountability and the role of experts in the governance of food and vaccine safety, I studied stakeholders' debates on public accountability of public health in China. I specifically focused on food and vaccine safety as China has suffered from many public health scandals in both fields, resulting in diseased and dying babies and sparking fierce discussions about accountability among scientific scholars and stakeholders, such as experts, the public, the journalists, local official, expert in research institution and clinician. The research question in this study was how accountability and trust were discussed following these public health scandals. To this end, I studied the perspectives, and knowledge of academic scholars and other stakeholders.

Chapter 1 presented a content analysis of how Chinese scholarship conceptualised public accountability of food safety during years when many incidents took place with infant formula production. The analysis of these scholarly debates shows how academia plays a prominent role in discussing food safety governance. A body of scholars, most of them working in disciplines like public policy, have argued in favour of strengthening centralised power. They have emphasised that a unified supervisory model and a top-down approach to the governance of food safety would help alleviate challenges in establishing boundaries between responsibility, information transparency, and governments dodging blame. Others have proposed de-centralisation and argued that decentralised power could facilitate food safety supervision and accountability as the food chain becomes increasingly complex. They have argued that decentralisation supplemented with (some degree of) stakeholder participation would help overcome deficits associated with top-down governance, including the risks that accompany absolute power, corruption and overly close ties between experts and the state. Involving stakeholders, so they have argued, would promote transparency, discussion and negotiation between the diverse ways to perceive risks, slowly creating the required support and participation to work towards consensus.

Subsequently, chapter 2, based on interviews in China, inquired into how diverse stakeholders, other than academic scholars, have attributed meaning to changes in accountability system and dilemmas associated with infant formula safety governance. To that purpose I interviewed parents, CDC experts, clinicians, journalists and one academic scholar. The analysis of these interviews shows that different stakeholders engaged in discussing the dynamics of infant formula governance view the governance and accountability landscape quite differently. Officials stress government reform to improve the efficiency of governance via means such as a centralised model entailing that several regulatory agencies are merged into one, strict accountability, top-down risk assessment and segmented information disclosure facilitated by a coordination system. The academic scholar stressed the need for a decentralised forum where non-state stakeholders participate in the accountability 
system - rather than the public sphere being included nominally - a position largely shared with the young mothers we talked to and many scholars whose work was reviewed in the previous chapter. Members of the media have perceived risks and benefits critically and have sceptically approached co-governance systems where centralised models and public participation were fused. They have continued to stress potential risks, such as the weak incentives associated with the top-down model, the extremely limited capacity of public participation and the lack of authority for third parties in the decentralised market.

Chapter 3 aimed to analyse how vaccination hesitancy and the governance of vaccination hesitancy in China are studied in Chinese academia. To that purpose, I used a similar methodology as in chapter 1 , namely a document analysis in the format of a scoping review. The findings of this study indicate that most studies on vaccine hesitancy have defined it as a problem related to vaccine incidents and vaccine safety. A smaller number of studies have defined it as a problem related to professional conduct, and the smallest number have defined it as a problem related to parental beliefs or concerns. Most studies have assigned the responsibility for vaccine hesitancy to governance system factors, such as an inadequate supervision model and reduced participation and transparency. As solutions, they have proposed reformation of the supervision model, a strict top-down accountability system and participatory turn in crisis response. A handful of studies have ascribed vaccination hesitancy to less responsive and less experienced doctors and relatively outdated technical equipment at the grassroots level. Professional training, resource investment and regulation of doctors have been proposed as solutions. Studies that have focused on parental doubts and beliefs have pointed to the influence of the media and inadequate public education. To address this, these studies have proposed public outreach and communication as solutions. A few studies have evaluated new policies formulated to tackle this problem and have pointed to diverse factors that have hampered the effective implementation of these policies.

Chapter 4 detailed a qualitative study to understand how stakeholders other than academic scholars have shaped the meaning of vaccine hesitancy in China, and its results indicate a large gap between expert and lay perspectives on vaccination hesitancy in China. CDC experts, clinicians and two of our parent respondents considered vaccines safe for the general public despite a few flaws in some regional areas. They favoured the NIP, based on how it was logistically organised: signing informed consent, single vaccine shots and the absence of antibody tests. They also justified past crisis responses as transparent and rational. The other half of the parent respondents and all the self-declared victims of vaccination presented different views. They considered vaccines unsafe and risky for their children. They also criticised compulsory signing of informed consent forms as a way to exempt doctors from responsibility for incidents. Contrary to the experts, these parents also preferred combined shots of vaccines and performing antibody tests on their children. They were not 
convinced by the responses of experts and public health bodies to vaccination incidents and called for more transparency and public engagement in crisis responses. A few independent experts and journalists mentioned the same risks in vaccine safety, vaccination organisation practices and crisis responses as these parents, and they considered parental mistrust in the NIP as the result of a failure of science popularisation in China.

In the following sections, 1 will compare my study of food and drug safety governance and articulate the strengths and limitations of the research reported in this thesis. Subsequently, 1 will relate these findings to the scholarship I introduced in the beginning of this thesis, namely public accountability studies, STS and PUS. I will also connect this study to other studies in the field of food and drug safety governance. Finally, I will briefly show how the analysis of stakeholders' debates in this thesis contributes to the future research agenda of, for instance, public accountability in the Covid-19 pandemic in China.

\section{Couching the findings by comparing stakeholders' debates}

On the basis of the analysis of public debates about food and vaccine safety governance, this study observed similarities as well as differences between these debates.

The analysis demonstrates the importance of technical instruments in improving institutional efficiency. Stakeholders in this study pointed to a range of instruments, including centralisation, a standardised accountability procedure, a standardised risk assessment and clear definition of responsibilities, a traceability system to increase information transparency, a scientific crisis response mechanism to alleviate public concern and a participatory turn to cope with the increasingly risky food and vaccine chain. According to Qu et al. (2009) and Chen (2013), this focus on technical instruments in food and drug safety governance discussions relates to the rapidly developing market-oriented economy of the $21^{\text {st }}$ century in China and the shift of China's political structure to a project-based governance, in parallel with the Chinese economic structure, and from a vertical political system to a horizontal administrative system. According to Shi (2015), project governance stresses that local states competitively apply for project funding from the central state and effectively manage the project, aiming to stimulate local governmental officials to perform their duty actively and to fuel local economic growth. To achieve project goals effectively, the local state relies on technical instruments ( $\mathrm{Qu}$ et al., 2009). During the project, these technical instruments play a prominent role in stimulating the efficiency of project-based governance and economic development, catering to political reformers' pursuit of technocracy in China (Chen and Zhang, 2015). In 2004, the central state enacted legislation to determine the authority position of technology and science in governing the country and consider the technicalisation, rationalisation and standardisation at the core of administrative system reform ( $\mathrm{Qu}$ et al., 2009). As such, much attention has been paid by 
stakeholders in this study to the technical rationality of food and vaccine safety governance. It is in this context that arguments for a participatory turn, notwithstanding the democratic potential, should be understood as contributing to instrumental and technocratic efficiency and not as arguments to increase democracy.

In addition, studies in this thesis highlight the pivotal role of the state in food and vaccine safety governance. Scholars and interviewed stakeholders shared the view that China's state has the power to control risks in the food and drug supply chain via establishing and enforcing laws, setting standards and goals and inputting and allocating regulatory resources (He and Thøgersen, 2010). In contrast, due to the inadequate competence of, the lack of financial support for and the deficient cooperation infrastructure among social organisations, these organisations are considered unable to play as prominent a role in the governance of food and vaccine safety in the unique Chinese context of 'small society and big government' (Stockmann, 2013; Teets, 2018). In addition, the conventional control of the state over the market and society has shaped the high reliance of the public on the government. Citizens deem food and vaccine safety protection as the inherent duty of the state and believe that the general public has neither ability nor social duty to ensure food and vaccine safety. As such, government actors should carry the blame for their malpractice in the event of a public health crisis

The analysis of debates about food and drug safety governance also shows differences between these cases. First, in the field of food safety governance, scholars and stakeholders in this study advocated for information traceability of food and vaccine safety co-constructed by non-state stakeholders to stimulate more information transparency aimed at facilitating public participation and ensuring food safety. Along this line, scholars and stakeholders in this study also considered information transparency critical in the governance of vaccine safety, but they insisted on limited information dissemination during vaccine scandals to relieve parental anxiety; media exposure amplifies the side effects of vaccine scandals, fuelling parental anxiety and inducing vaccine hesitancy. As such, they called for a degree of governmental intervention to contain negative media reports.

Second, stakeholders' narratives in this thesis revealed that they see more room in food safety governance for a shift from bureaucratic control towards a co-governance approach involving diverse social actors who hold formal and informal expertise. That is because of the increasingly risky food chain and growing civil awareness in the modern society of China. Social actors - perceiving different risks in food safety governance than the state - have thus called for a more inclusive food safety governance and a participatory turn to ensure food safety and to construct an inclusive governance system (Wu et al., 2018). However, food safety governance remains characterised by administrative control in China, implying that the state has no duty to respond to public demands. 
Also, there is no formal system to allow public engagement in the quasi-authoritarian regime of China. This lack of responsiveness in the food safety governance system has spurred public mistrust, and Chinese citizens have had to express their dissatisfaction and their needs via informal platforms like Chinese social media communities. To restore the credibility of and unload the burden of the state, to improve the adaptability of the authoritarian regime and to contain the increasingly risky food supply chain, the central state renewed the Food Safety Law in 2015 to develop a co-governance system allowing social actors with different expertise and knowledge to engage in food safety governance attuned to the various demands of the public. In doing so, this legislation has defined the responsibilities of the public, the media, third parties and industry associations to co-govern food safety in China.

Contrary to the co-governance of food safety, vaccine safety governance stakeholders highlighted the ascendancy of medical experts in parallel with governmental intervention in the governance of vaccine safety and vaccination. They argued that due to traditions and expectations of medical autonomy in the Chinese national immunisation programme, the governance of the NIP stresses medical autonomy and expert neutrality to solve patients' problems professionally. To this end, experts who have received training on professional knowledge and medical ethics and obtain licenses play an authoritarian role in the decision-making of vaccination, and lay people, who are regarded as insufficiently knowledgeable to conceptualise vaccinations risks, are rejected, aiming to deter outside interference of vaccination practice (Wuensch et al., 2013). However, the lack of public control over medical practice has provoked inappropriate behaviour by medical doctors and lack of attunement to public interests; examples that were mentioned were refusing pre-vaccination screening and 30 min post-vaccination observation and impatience and lack of response in dealing with parents' questions. In this context, Yao (2019) points to two governance models of medical practice, namely administrative regulation and supervision of medical service recipients. However, Lay people with the less scientific expertise are considered incapable of scientifically conceptualising the risks of vaccination, even though they can perceive risks based on their personal experience (Yao, 2019). Against this background, Feng (2011) argues that states become the reliable actor in intervening in medical practices to control the abuse of clinical autonomy in the quasi-authoritarian regime of China, where the state has the capacity and legitimacy to do so. Nevertheless, state interventions have not been as satisfactory as expected because they are unable to meet the diverse demands of the public (Yang, 2015). As such, Yao (2019) suggests the intervention of third-party organisations to enable diverse stakeholders beyond the state to engage in the medical practice so as to attune to the various demands of the public. Future studies should reflect how to reach a compromise between medical autonomy and societal actors maintaining the public interest and values. 
Table 1. Comparisons of debates on the food and vaccine safety governance in China

\begin{tabular}{|c|c|c|}
\hline & Discussing food safety governance & Discussing vaccine safety governance \\
\hline \multirow[t]{2}{*}{$\begin{array}{l}\text { Main } \\
\text { differences }\end{array}$} & $\begin{array}{l}\text { Calls for co-governance of experts and } \\
\text { non-experts }\end{array}$ & $\begin{array}{l}\text { Emphasizes medical autonomy of } \\
\text { vaccination and expects a strict } \\
\text { administrative intervention to deter the } \\
\text { abuse of clinical autonomy }\end{array}$ \\
\hline & Calls for information transparency & Calls for limited information transparency \\
\hline Main & \multicolumn{2}{|c|}{ Stresses utilisation of technical instruments to improve institutional efficiency } \\
\hline similarities & \multicolumn{2}{|c|}{$\begin{array}{l}\text { Highlights the pivotal role of the state in food and vaccine safety governance in the } \\
\text { quasi-authoritarian regime of China. }\end{array}$} \\
\hline
\end{tabular}

\section{Strengths and limitations}

This thesis is the first of its kind to present the food and drug safety governance systems in China from the perspectives of diverse stakeholders, capturing different arguments of social groups (officials, doctors, experts, citizens, journalists etc.) through literature analysis and interviews in China. The results of this study should be considered in light of certain limitations. First, it focuses on the debates of stakeholders pertaining to food safety governance under the segmented model of China. However, after the collection of empirical data, the Chinese state has shifted its regulation system toward a centralised model in which several regulatory bodies were merged into the State Administration of Market Regulation in April 2018 (Zhang et al., 2018; Shan and Liu, 2020). It would thus be interesting to study how discussions about public accountability will continue in relation to these changes. However, the analyses of this study regarding food governance are still valuable, as Chinese stakeholders in this study have fully discussed both the centralised and decentralised model with respect to food safety governance.

Second, the scoping nature of the review applied in this study means that it is possible some studies were missed, given the high diversity of terminology in Chinese databases regarding food and vaccine safety governance. Terms like polity interaction - meaning interaction and collaboration among the local states in the governance of food safety - and vaccine circulation - referring to the inappropriate cold storage of vaccines during transportation, resulting in ineffective vaccine - were not included in the search, though they may have resulted in relevant texts. Over time, as these Chinese databases are used more and links between Western and Chinese debates are solidified, I would expect higher terminological standardisation, and it would be more feasible to conduct literature searches using both Chinese and Western databases.

Finally, I chose urban areas to collect qualitative data for practical reasons. However, the studies of Jiang et al. (2013), He (2014), Xu and Zhou (2014) Zhang (2017) and Zhang and Lu (2019) showed that food safety risk and vaccine hesitancy were rising in rural areas as well, but issues 
regarding vaccine hesitancy and in the governance of food safety varied between urban and rural areas, entailing different strategies to deal with them. As such, future studies should be concerned about geographical characteristics related to food and vaccine safety governance in China.

\section{Reflecting on the findings within the theoretical lenses}

This study aimed to understand how the governance of food and drug safety is constructed as a public issue in China. To that purpose, I employed the perspectives of public accountability studies, STS and PUS. While these fields have developed in a democratic, Western context, they have also facilitated the understanding of food and vaccine safety governance infrastructure in the quasi-authoritarian regime of China. These academic disciplines emerged in the context of the critical study of relationships between expertise systems and society and developed in parallel with ongoing democratisation and public participation movements in Western democracies. It will be interesting to see how the adoption and further development of public accountability studies, STS and PUS in the non-democratic context of China will work out.

\subsection{Understanding public accountability practices in China}

This study on perspectives of public accountability in China draws from the Western public accountability paradigm conceptualised by Bovens et al. (2014), in terms of enhancing openness to scrutinise government action, public participation in expressing public concern, and discussions, bargaining and communication with one another to reach a compromise. It also offers insights differing from the narratives of Bovens and colleagues about Western public accountability, with respect to, for instance, inclusivity and participation under authoritarian political control, the pursuit of participation instead of institutional efficiency, the control over the media to alleviate public distrust and external accountability mechanisms coming into play through social media in a less democratic country.

According to Papadopoulos (2014), public accountability in the West focuses on forms of multi-level governance where both public actors and non-public actors of different natures are involved in the process of collective decision-making to construct democratic governance. My study shows that multi-level governance is important in China as well, but it also shows that the engagement of the public, the media, social organisations, experts and officials is steered by the state. People who are unable to utilise scientific knowledge to conceptualise risks and non-state organisations that are not authorised by the state are marginalised and excluded in multi-level governance. Non-state entities that are involved in the process of decision-making and policy-implementation do not represent very diverse populations, are unable to sufficiently give voice to public values and are unlikely to scrutinise government actions (Rosenbaum and Lee, 2019). 
Therefore, while this thesis shows that respondents and scholars recognised the active necessity of inclusive and participatory governance, all levels of the multi-level governance framework are, to varying degrees, under political control.

In addition, Bovens et al. (2014) shows that public accountability is about democracy, and public engagement contributes to the democratic and inclusive forms of decision-making in West. My analysis of debates about food and drug safety governance shows that several scholars considered public engagement as an approach to reflect public interests and to construct democratic governance in China, but also observed that it was being repurposed to the context of institutional efficiency. Introducing public engagement in governance in China could be considered a means to unload the burden of states and enhance regulatory efficiency (Rosenbaum and Lee, 2019). In this regard, the analysis of stakeholders' debates shows that while public accountability is viewed as a democratic virtue in West, public accountability is repurposed as a technical instrument to favour institutional efficiency in the non-democratic regime of China.

Kuiper and Hart (2014) stress the importance of information transparency and in scrutinising government actions in Western democracies. The mass media and internet are abuzz with reporting, speculation and judgement about the performances of relevant actors, which are public scrutiny of the causes and management of public health crises in food and vaccination, like the horse meat scandal in Europe in 2013 (Frohlich, 2013). To avoid reputations being damaged, a social organisation will be proactive to disclose information and to respond to crises (Kuiper and Hart, 2014, p. 590). My study identifies the critical role of media reports in information transparency. For instance, media reports promoted public concern and public accountability during the Changchun Changsheng vaccine scandal in 2018. However, my analysis also highlights state control over media to restrain media rumours and alleviate public panic caused by negative media reports during food and drug crises. My observations are in line with the work of Smith (2010), who argues that the Chinese central state has rigorous control over society and is pacifying the public to maintain political stability. Stakeholders in this study thus argued that journalism in this authoritarian regime was not as free as in Western democracies and had to conform to the political goals set by the state.

Uhr (2014) argued that both internal and external accountability play an important role in ensuring officials take responsibility in a democratic system. The former focuses on constitutional norms and administrative procedures to scrutinise and sanction public officials, aimed at preventing abuse of power and promoting officials' adherence to the rule of law. The latter emphasises that various societal actors are involved in the formulation of policy goals to hold public servants accountable through setting accountable standards of behaviour. In less-developed systems, where local citizens may be highly dependent on government, it is difficult to hold the government accountable. Nonetheless, the analysis of stakeholders' discussions in this study shows that external 
accountability does play a role in the authoritarian regime of China. Accountability infrastructure includes a number of stages: perceiving risks, disclose information, causing social concern and discussion, and imposition of remedies, entailing that neither internal accountability nor the external accountability could complete the procedures of accountability on its own. In the modern society of China, citizens strive to disclose more information in social media communities to fuel public distrust and raise state concern, which enable the supervisor state to conduct top-down accountability. In this regard, stakeholders in this study suggested that it was difficult for an external entity to hold the government accountable in the formal system of an authoritarian state. The development of informal forums in the modern society of China, such as Sina Weibo and Zhihu, provides an opportunity for external actors to expand their influence on top-down accountability.

\subsection{Portraying the advance of STS and PUS in China}

Over the course of many decades, STS and PUS have revealed the hubris of scientific expertise and helped problematise its relationship to public trust. These fields have revealed how symmetrical communication and interaction with non-scientific actors and stakeholders allows the co-production of knowledge. My study demonstrates a demand for more symmetrical communication in China as well, where a deficit model-based strategy of science popularisation has produced over-politicised forms of science communication.

According to Goldenberg (2016), the deficit model presumes that scientific knowledge is a sufficient basis for decision-making and places it in a superior epistemic position. Painting with a very broad brush, it considers the public to be ignorant about science and proposes public education as a strategy to diminish any public resistance to science-endorsed policies. The model has been heavily criticised for not considering the role of social context, public interests and other forms of legitimate expertise. Consequently, a symmetrical approach to science communication has been developed, to avoid the problems of the deficit model. Suldvsky (2016) argues that the deficit model, despite the critics, is still dominant in Western countries as many institutions have emphasised that the epistemic authority of science is needed to transfer information, improve attitudes and alter behaviour. In health care contexts the deficit model is still embraced because professionals think that individuals need help in making decisions (Bar-Tal and Maksymiuk, 2013).

The analysis of the perspectives of experts and laypeople regarding vaccine safety governance discussions shows that deficit model-based science popularisation plays a dominant role in science communication in China. This continues to be the case, even after China has moved beyond deficit model-based science popularisation towards science communication in order to keep pace with Western scholarship (Chen et al., 2009; Zhang, 2015). Science popularisation in China stresses the dissemination of science and the dominance of the state, with the purposes of improving the scientific 
literacy of the population, rejuvenating the productivity of the country and serving communist ideology (Zhang, 2015). Despite the shift from science popularisation to science communication, the state still dominates science communication and invites 'policy-compatible' experts as their spokespersons in public forums, aiming to mitigate public distrust in the state and in science, especially during food and drug crises. It appears that stakeholders in this study attributed the dominance of the state in science popularisation and communication to the state being afraid that public engagement would erode their authority; thus the state aligned with science to assure their legitimacy in the governance of public health.

Interestingly, Wang (2010) and He (2016) understand this state-led science communication not in terms of the political system as such but in the context of Asian Confucianism. He (2016) argues that Confucianism offers a democracy reform programme specific to China. The idea of Confucian democracy stresses the construction of harmonious public spaces to balance individualistic rights and the duty to communities and society. To this end, Confucianism promotes public values such as filial piety, trustworthiness, social harmony, respect for the elderly and respectful deference (Jayne, 2018). In the process of constructing Confucian democracy and a harmonious public space, Confucianism stresses the rectification of government to normalise the moral life of individuals, which contrasts with a liberal-democratic state that aims to protect the rights of individuals from the state. For instance, the Zhejiang province in China in 2010 established a law to educate citizens on the virtue of helping each other and to punish those who do not attempt to save the life of a person who is in danger (He, 2016; Chang et al., 2019).

Although China has reoriented science popularisation to science communication in parallel to the fast development of STS in Western democracies, science communication in China still follows a top-down approach by affording technical experts the superior epistemic position, deterring symmetrical science communication between experts and the public. Western scholarship points to the challenges of public engagement in risk construction and technical decisions and shows that public engagement is constrained by the formal discourse of experts as well (Suldovsky, 2016). Citizens are often considered to be incapable of contributing to risk assessment. As a consequence, technical experts do not admit novel viewpoints of laypeople or critiques of the framing of a problem and reject the role of lay people in risk assessment (Jasanoff, 2011; Zhang, 2015). To address these asymmetrical relationships, STS scholarship suggests a participatory governance system where lay people should be treated as knowledgeable citizens that can process, learn and produce experiential expertise in Western democracies (Jasanoff, 2014). Instead of counteracting the privileged status of experts and considering the public as knowledgeable citizens, as described by Jasanoff (2017), the analysis of this study emphasises that in China lay people designate public experts as mediators to negotiate, debate and reach compromises with technical experts in risk communication. 
Additionally, Chinese STS scholar Liang et al. (2019) argues that in China, deficits in bilateral communication and public engagement in knowledge production pertaining to public health governance have stimulated the development of informal forums, where experts and laypeople initiate communication and debates on the internet, such as the Sina Weibo and Zhihu communities, with fewer political restraints. In line with this, this study reveals the importance of expert-citizen communication about food and drug safety in Chinese social media communities to assuage public trust; these practices compensate for deficiencies in public disclosure in the formal system of an authoritarian state and help bureaucratic institutions function under modern conditions in China. Chapter 4 showed that the construction of a private, informal forum to facilitate communication about vaccine safety does not mean the loss of the formal science communication system in China in these fields. Considering the tensions between vaccination experts and the public with respect to the risks in the vaccination programme, investing in symmetry - allowing the public to express their concerns about vaccination - may help the NIP attune to the demands of the public.

\subsection{Some further reflections}

When compared to other studies in the fields of food and drug safety governance in China, this thesis does not address some arguments that regularly feature in these studies. This is a result of the design and focus of this work.

The analysis of this study reveals that the stakeholders diagnosed specific deficits in food and vaccine safety governance system and proposed a centralised model as a means to intensify the top-down regulation and accountability system, and that is in line with the suggestion of Tullock (2013) that this will suppress the rent-seeking environment to favour institutional efficiency. Winter and May (2015) and Li (2017) attribute food and vaccine safety issues to malpractice of the frontline policy enforcers and suggest stringent regulation and accountability posed on them to limit their discretionary power during frontline policy practice. Additionally, Liu and Liu (2014) propose improving street bureaucrats' capacity, social responsibility awareness and loyalty to politics to improve the efficiency of policy implementation through a centralised model reform.

My study shows how discussions about food and drug safety governance in China cover issues like stakeholder participation and multi-level governance that are considered quite common characteristics of Western governance practices. However, it also shows that the authoritarian political system limits the development of them. Amako (1997) understands this in the context of Chinese history, where a Chinese bureaucratic empire totally dominated Chinese society, and there was no constraint from society on the power of the emperor. China never had the benefits of competing authorities and divided powers and thus opposed the move towards pluralistic democracy. According to Bell (2016), in the modern society of China, the emergence of a middle class and the 
awakening of civil consciousness have stimulated the demand for citizens to engage in politics. Consequently, diverse social organisations, committed to engaging in social governance, are rapidly growing. Local states, however, have been alert to the emergence of non-state associations, which might challenge their authority. They therefore have dominated the development of social organisations by setting up standards, orienting goals and shaping the pattern of social organisation in China.

However, discussions about food and vaccine safety governance will develop in global collbaoration. Lepeintre and Sun (2018) emphasise that as a vital part of global food and drug supply chain, China cannot fully address its food and drug safety issues by itself. It will have to collaborate with importing or exporting countries to do so. Lepeintre and Sun (2018) argue that China should learn from the EU's experience in food and drug governance, given that the EU has established an effective food and drug safety governance system after several food scandals at the end of the $20^{\text {th }}$ century, such as the bovine spongiform encephalopathy crisis in the mid-1990s and the dioxin crisis in 1999. China is now also updating its governance system to mitigate public distrust caused by a series of food and drug scandals over the last few decades; learning from the EU will help China construct a robust governance system to deal with crises and public distrust (World Health Organisation, 2014).

The analyses of stakeholders' debates on food and vaccine safety governance can also teach us about the COVID-19 pandemic response in China, which unfolded when this thesis was almost completed. The lack of public participation, little information transparency and accountability deficits have fuelled public anxiety, social panic and distrust, in China and globally. The absence of a formal communication system between the state, experts, and the public has forced citizens to express their concerns and discuss the coronavirus crisis response on social media, such as Zhihu, Sina Weibo and WeChat. The fierce debates about the coronavirus crisis response that ensued there again raised the question on how to construct public accountability and public trust. In the valorisation section, I propose a research agenda in which public health crisis response, on the one hand, and more stable institutional forms of inclusive governance and public accountability, on the other - both featured in this thesis - are examined and evaluated in the context of this pandemic. If there is ever a time to learn, it is now.

\section{Conclusion}

The governance of public health is steered by the state in China, and persistent public health crises related to baby food and vaccine safety have decreased public trust in the governance system and the accountability of public health authorities. Different stakeholders pointed to accountability deficits, lack of information transparency and lack of participatory governance as sources of public distrust. 
As solutions, they proposed an even more stringent and centralised top-down accountability system, an information traceability system, a more symmetrical science communication mechanism between experts and the public and public engagement in risk assessment practices. Compared to Western scholarship, most of the Chinese stakeholders in this study preferred to consider public accountability, social engagement and scientific knowledge as technical instruments favouring institutional efficiency rather than as genuine deliberative practices that serve democratic virtues.

\section{References}

Amako, S., 1997. Politics and Society. China in the Twenty-First Century: Politics, Economy and Society. United Nation University Press. pp. 157-207.

Bar-Tal, Y.B. and Maksymiuk, R.A., 2013. Patient perceptions of physicians' epistemic authority when recommending flu inoculation. Health Psychology, 32(6), pp. 706-709.

Bell, D.A., 2016. The China Model: Political Meritocracy and the Limits of Democracy. Princeton University Press.

Bovens, M., Goodin, R.E. and Schillemans, T., eds., 2014. The Oxford Handbook of Public Accountability. Oxford University Press.

Cai, C., 2015. From "big government" to "wise government": the logic of Chinese government transformation—- from the perspectives of transaction cost and politics. Public Administrative Review. 2, pp. 99-124.

Chang, Y., Lau, M. and Calogero, P., 2019. Participatory governance in China: Analysing state-society relations in participatory initiatives in Suzhou. International Development Planning Review, 41(3), pp. 329-352.

Chen, F., Shi, Y. and Xu, F., 2009. An analysis of the public scientific literacy in China. Public Understanding of Science, 18(5), pp. 607-616.

Chen, J., 2013. Project system and grassroots government mobilization - A sociological survey of socialized project operation. Chinese Social Science, 2 (3), pp. 1-14.

Chen, J. and Zhang, Q., 2015. Policy implementation fluctuations and grassroots governance issues. Sociological Research, 30(3), pp. 23-45.

Dai, W. and Zhu, Q., 2018. Research on Information Mechanism of Risk Amplification in Media Environment-Taking 2016 Shandong Vaccine Event as an Example. Journal of Southwest University for Nationalities (Social Sciences Edition). 39, pp. 153-157.

Feng, S.Z., 2011. Formation and variation of China's state movement: Based on the holistic interpretation of regime. Open Times, 1 (2), pp. 25-47.

Frohlich, X., 2013. What is the beef with horsemeat? Risk and Regulation, 25, pp. 20-21.

Goldenberg, M.J., 2016. Public misunderstanding of science? Reframing the problem of vaccine hesitancy. Perspectives on Science, 24(5), pp. 552-581.

He, B. and Thøgersen, S., 2010. Giving the people a voice? Experiments with consultative authoritarian institutions in China. Journal of Contemporary China, 19(66), pp. 675-692.

He, B., 2016. Confucianism and democracy: Testing four analytical in an empirical world. Taiwan Journal of Democracy, 12(2), pp. 59-84.

He, L., 2014. Public opinion response to food safety network. Rural Economy, 1(2), pp. 18-20.

Jasanoff, S., 2011. Technologies of humility: Citizen participation in governing science. In: Winston, M. and Edelbach, R. ed. Society, Ethics and Technology. Cengage Learning. pp. 99-121.

Winston, M. and Edelbach, R., 2011. Society, ethics, and technology. Cengage Learning.

Jasanoff, S., 2014. A mirror for science. Public Understanding of Science, 23(1), pp. 21-26.

Jasanoff S., 2017. Science and technology. In The Handbook of Science and Technology Studies (Revised ed.). The MIT press. pp. 260-283. 
Jayne, M., 2018. Chinese Urbanism: Critical Perspectives. Routledge.

Jiang. Y., Yin, H., Shi, Y., Yuan, Y., Cao, W. and Zeng Q., 2013. Analysis of the second-class vaccination rate and influencing factors of children aged 1 to 6 years in rural and urban areas of Chongqing. China Health Education,3(7), pp. 605-607, 630.

Kuipers, S. and 't Hart, P., 2014. Accountability for crises. The Oxford Handbook of Public Accountability. Oxford University Press.

Lepeintre, J. and Sun, J., 2018. Building Food Safety Governance in China. Luxembourg Publication Office of The European Union.

Li, Q., 2017. Research on implementation of frontline public policy in current China. In 2nd International Conference on Contemporary Education in 2017, Social Sciences and Humanities. Atlantis Press.

Li, H., Gong, L. \& Fan, C., 2019. The formation mechanism of public response behavior in drug safety incidents. Journal of Public Administration, 16(3), pp. 97-107.

Liang, J., Liu, X. and Zhang, W., 2019. Scientists vs laypeople: How genetically modified food is discussed on a Chinese Q\&A website. Public Understanding of Science, 28(8), pp. 991-1004.

Liu, P. and Liu, Z., 2014. The types of street bureaucratic policy alternative implementation and their explanations-Based on the case study of food safety supervision and enforcement in County H. China Administration, 2(5), pp. 103-107.

Papadopoulos, Y., 2014. Accountability and multi-level governance. In The Oxford Handbook of Public Accountability. Oxford University Press. pp. 273-288.

Qu, J., Zhou, F. and Ying, X., 2009. From overall control to technical governance: A sociological analysis based on China's 30 years of reform experience. Chinese Social Science, 6(2), pp. 112-121.

Ren, Y., An, Y. \& Duo, X, 2011. The transformation of government functions in food safety supervision and strategy selection: a case study based on the Beijing market. Journal of Public Management, 8(1), pp. 16-25.

Rosenbaum, A. and Lee, C.J., 2019. State and Society in China: The Consequences of Reform. Routledge.

Shan, C. and Liu, M., 2020. Medical device regulations in China. In: Bountrand J.P. ed. Biocompatibility and Performance of Medical Devices(Second ed.). Woodhead Publishing. pp. 475-488.

Shi, P., 2015. The bureaucracy for the body, the project for the purpose: A discussion on the organization of a central project operation. Society, 5(3), pp. 1-12.

Smith, G., 2010. The hollow state: Rural governance in China. The China Quarterly, 203, pp. 601-618.

Stockmann, D., 2013. Media Commercialization and Authoritarian Rule in China. Cambridge University Press.

Suldovsky., 2016. In science communication, why does the idea of the public deficit always return? Exploring key influences. The Public Understanding of Science, 25(10), pp. 415-426.

Teets, J., 2018. The power of policy networks in authoritarian regimes: Changing environmental policy in China. Governance, 31(1), pp. 125-141.

Tullock, G., 2013. The Economics of Special Privilege and Rent Seeking (Vol. 5). Springer Science \& Business Media.

Uhr, J., 2014. Accountable civil servants. In: Bovens, M., Goodin, R.E. and Schillemans, T. eds. The Oxford Handbook of Public Accountability. pp. 226-241.

Wang, Y.K., 2010. Harmony and War: Confucian Culture and Chinese Power Politics. Columbia University Press.

Winter, S.C. and May, P., 2015. Street-level bureaucrats and regulatory deterrence. In: Hupe, P. and Hill, M. ed. Understanding Street-Level Bureaucracy. pp. 133-152.

World Health Organization., 2014. WHO Country Cooperation Strategy at a Glance: Paraguay (No. WHO/CCU/14.03/Paraguay). World Health Organization. https://apps.who.int/iris/handle/10665/136824

Wu, L., Liu, P., Lv, Y., Chen, X. and Tsai, F.S., 2018. Social co-governance for food safety risks. Sustainability, 10(11), pp. 4246.

Wuensch, A., Tang, L., Goelz, T., Zhang, Y., Stubenrauch, S., Song, L., Hong, Y., Zhang, H., Wirsching, M. and Fritzsche, K., 2013. Breaking bad news in China - The dilemma of patients' autonomy and traditional 
norms. A first communication skills training for Chinese oncologists and caretakers. Psycho - Oncology, 22(5), pp. 1192-1195.

Xu, Y. and Zhou, B., 2014. Differential research on urban and rural food safety supervision. Anhui Agricultural Sciences, 3 (11), pp. 249-250, 252.

Yang, Z., 2015. The changing relationship between Chinese urban medical professionals and the state since the republican period: The perspectives of the sociology of professions. Sociological Studies, 30(3), pp. 46-48.

Yao, Z., 2019. State control and doctors' abuse of clinical autonomy: An empirical analysis of doctors' clinical practice in Chinese public hospitals. Chinese Journal of Sociology, 5(1), pp. 29-56.

Yu, J., Zhu, X. \& Gao, X., 2020. The common evolutionary logic of the transformation of government functions and the establishment of a market regulatory governance system-a case study based on vaccine regulatory governance system and response to crisis events. Management World (2), pp. 7-16.

Zhang, J.B., 2015. The credibility paradox in China's science communication: Views from scientific practitioners. Public Understanding of Science, 24(9), pp. 913-927.

Zhang, H. and Lü, Jie. 2019. Regional disparity in food safety risk and its dynamic evolution: An Empirical study based on Dagum Gini coefficient decomposition and non-parametric estimation. Journal of Public Management, 16(1), pp. 77-88.

Zhang, Z., 2017. The construction of multiple governance models of rural food safety. Forum on Law, 4 (3), pp. 12-18.

Zhang, Z., Godefroy, S.B., Lyu, H., Sun, B. and Fan, Y., 2018. Transformation of China's food safety standard setting system - Review of 50 years of change, opportunities and challenges ahead. Food Control, 93, pp. 106-111. 


\section{Valorisation of research insights}

\section{Valorisation}

China's public health governance has put experts and their technical rationality in an authoritative position to promote institutional efficiency since China's economic reform in the 1970s. The high reliance on technical rationality inevitably results in insufficient attention on lay expertise and the alignment with political goals causes the less attunement to public benefits and demands in public health governance. Meanwhile, the persistent public health crises over the last few decades have solidified the gap between risk perceptions of experts and citizens, and the lack of responsiveness and participation in the public health governance system has fuelled public distrust in the modern society of China. This study inquired into diverse Chinese stakeholders in food and vaccine safety governance to understand how expert and lay knowledge are related to public accountability of public health. In this valorisation chapter, I will show the social relevance, values and practical recommendations of this study to academia and societal actors, and I will point to the value of this study for studying the COVID-19 crisis management in China and for future public health governance.

\section{The value of this study for academia}

\subsection{The importance of a multiple stakeholder perspectives in study designs}

Chinese academics tend to interview single stakeholders, such as experts, public officials or citizens, privileging a particular style of evidence when presenting knowledge regarding food and vaccine safety governance (Yan, 2010; Hu, 2018). However, Miles (2017) criticises this, saying that single stakeholder perspectives breed partial knowledge and engender epistemic injustice. My study shows that, for instance, interviews with governmental actors will not present as accurate a view because, constrained by political forces, governmental actors often dare not express their true opinions and experiences. Therefore, it is important to interview diverse stakeholders.

Why are diverse stakeholder perspectives important to academic research? Paphitis (2018) argues that doing research with diverse stakeholder perspectives is related to systematic knowledge production as well as epistemic justice. According to Fricker (2007) and Felt (2017), it is important to ask who has a voice to make legitimate knowledge claims, who defines what matters, and who participates in imagining and shaping the future. Asking these who questions points to concerns not only about actors and identity but also exclusion, inequality and social injustice. Scholars who focus 
on single stakeholders implicitly assign a lower level of credibility to other stakeholders' testimony or report. Aware of that, this study thereby engaged with diverse stakeholders, aiming to present a broader perspective on public health governance and offer a methodological example of a qualitative study in China. Furthermore, in chapter 5, I examined special experiences and arguments of online self-proclaimed vaccination victims regarding vaccine safety and vaccination governance: they represented a dissenting voice that had been suppressed by the state to maintain a high vaccination rate across the country, and this position is rarely reflected in Chinese academia. Understanding different stakeholders' narratives will help to construct a robust food and vaccine governance system in China, so future studies should pay more attention to groups like vaccination victims whose knowledge, experience and attitude are underrepresented by academia.

\subsection{The importance of studying inclusive governance in China}

Influenced by the political environment, there is an overwhelming majority in Chinese academia that studies the role of technical rationality in public health governance to promote institutional efficiency aimed at ensuring food and drug safety and public trust. As a consequence, less research deals with the construction of inclusive governance systems in the quasi-authoritarian regime of China. An inclusive governance system entails a participatory turn established in the food and vaccine safety governance system to allow diverse stakeholders to disclose information, negotiate and discuss decision-making processes to attune to the various demands of societal actors.

Jeffrey and Sigley (2009) argue that an inclusive governance system is important not only in Western contexts but also in the quasi-authoritarian context of China to attune to public interest and to adapt the Chinese bureaucratic system to modern society. In line with that, this study shows that public mistrust in the governance of food and vaccine safety in China flows not only from regulatory deficits and lack of efficiency but also from insufficient information transparency and lack of public participation in the food and drug safety governance system. Despite the fact that the deployment of technical instruments has improved the operational efficiency of bureaucratic systems in China, the unresponsiveness and non-participatory nature of the Chinese bureaucratic system has decreased public trust and failed to attune to public demands. Consequently, the wider public has expressed their dissatisfaction and distrust on social media.

As my thesis shows, many respondents would favour a Chinese governance system that is more responsive and inclusive and aims to increase the credibility and legitimacy of the bureaucratic system in China. In spite of the establishment of a public complaint system by the state to engage the public in monitoring risks in food and safety and to improve the responsiveness of the bureaucratic system to public demands, my study shows that the public is unlikely to genuinely become engaged. Social organisations with less authority and regulatory resources are not acknowledged as serious 
partners in Chinese food and drug safety governance. Additionally, as a high threshold is set by the state and technical experts, laypeople are unable to engage in the risk assessment and process of decision-making pertaining to food and vaccine safety governance. For fear of expert authority being eroded, symmetrical science communication between experts and the public has not been developed. My study suggests that, as a response to that situation, the public designates specific public experts to engage in decision-making to challenge experts that are affiliated with state institutions, to protect public interests. My study indicates that more studies about the collaboration between experts and laypeople in public health governance can be conducted in Chinese academia to remedy these deficits.

\subsection{Importance of adapting methods and ethics to the Chinese context}

China, as it rapidly transitions from a pre-industrial to a largely industrial and, in certain aspects, even post-industrial state, provides a fascinating window to processes of rapid modernisation, in which increasing social issues, such as public health scandals and trust crises, stimulate widespread concern in academia. As such, it is important to utilise Chinese academic databases and do fieldwork in China to study these social issues. This study suggests that literature research is important to be careful to use terminology extracted from Western academic discussions to search resources in Chinese academic databases. This study affords a lesson for doing fieldwork in China as well. In general, academia expects standard procedures to invite people to participate and to organise informed consent. However, performing a qualitative study in China, including fieldwork and interviews, is complicated. In practice, affected by a sensitive political environment and low social trust, getting access to potential participants via standard procedures is not feasible in China (Heimer and Thøgersen, 2006). Local officials are reluctant to participate in field investigations for fear of negative reports, damage to their reputations, and subsequent administrative accountability. Chinese citizens also generally distrust interviews conducted by strangers, and they are reluctant to openly express personal opinions. In this study, I adopted informal ways, such as gift-giving and acquaintances as mediators to establish first contact, of establishing a private, trusting relationship with potential participants. Therefore, this study suggests that organising access to respondents by establishing personal relationships could be an option to conduct fieldwork in China when formal ways fail to work.

\section{Impact on societal actors in China}

\subsection{The importance of balancing expert and lay knowledge in public health governance}

In China the role of scientific experts to promote institutional efficiency results in large public distrust of public health governance. This study suggests that the involvement of laypeople's experiential knowledge of food and vaccine safety governance may be beneficial for public trust, risk monitoring 
and attuning to public interest. To facilitate public participation and balance expert and lay knowledge in Chinese public health governance practices, this study suggests that the development of more symmetrical science communications and interactions between experts and laypeople would be fruitful. Chapter 5 suggested that laypeople delegate their own experts $\mathrm{s}$ mediators to contest technical public health expertise and to reach a compromise with experts. This could be an important step in this process.

\subsection{Reducing public alienation of experts}

Food and vaccine scandals over the last decade have demonstrated different risk perceptions of food and vaccine safety between experts and public, resulting in part of the public becoming suspicious of expert knowledge. Experts who were working in public institutions were salaried by the state, aligned with political goals which decreased their public credibility. Technical experts were seen as not considering the public interest, as perceiving laypeople as naive and ignorant and as excluding the involvement of lay knowledge. My analysis of stakeholders' perspectives suggests that to mitigate public alienation, an independent expert risk assessment committee on food and vaccination governance should be established to professionally assess risks without political intervention. This study also suggests that experts should cultivate their social responsibility awareness, and their research should be accountable to citizens as their research funding comes from taxpayers. Chapter 5 suggested that experts should engage in public events regarding vaccine safety governance to communicate with the public on a basis of equality and respect. The state should reduce its intervention in science communication so that science can freely attune to public interests and values.

\subsection{Empowering social organisations in China}

In China several NGOs are active Chinese charity organisations but some are organisations like the Red Cross. Because most of these organisations have little capacity and regulatory resources, they are unable to effectively engage in public health governance in the quasi-authoritarian context of China. This study suggests that NGOs should empower themselves by obtaining funding and other resources through market competition and society support, rather than by relying on the state. To gain public trust, non-expert entities should keep their operations transparent as well.

\section{Impact on future public health governance}

\subsection{Managing the COVID-19 crisis and public trust in China}

This thesis studied public accountability of public health governance in China through food and vaccine scandals, and the theoretical perspective that I used provides a lens for understanding China's 
the coronavirus disease 2019 (COVID-19) crisis and the management of public (dis)trust management as well. During COVID-19 in China, the crisis response of the state, such as reprimanding informants who disclosed information about coronavirus online without state permission and lack of information transparency and public participation, incited public panic, anger and distrust, and citizens were roaring on social media to hold Wuhan state and China's public health governance system accountable. Against this background, it is important to understand how public accountability and public distrust during the COVID-19 pandemic are portrayed as public issues and how they are debated by Chinese stakeholders.

According to Yang (2020), a large numbers of citizens have shown their distrust on social media during the COVID-19 pandemic in China, and this public distrust was rooted in the alignment of experts with political goals, neglecting public interest and demands. In particular, CDC experts have repeatedly announced the low mortality of coronavirus and limited information transparency to pacify citizens and maintain social stability. CDC experts have strived to persuade citizens to trust in science unconditionally, referring to what the state and experts have accomplished for the benefits of the masses. Moreover, CDC experts were not actively involved in frontline crisis management but competitively published articles related to the coronavirus crisis for scientific prestige, inciting public anger on social media and demanding unreliable CDC experts be held accountable.

Studying public accountability and public trust during the coronavirus crisis in China from the perspective I developed in my thesis will stimulate Chinese academia to explore how a more participatory governance system may respond to the rising public distrust during the COVID-19 crisis. Meanwhile, investigating public distrust and demands of COVID-19 crisis response in China will foreground the critical role of NGOs and identify the deficiencies in their operations during the Covid-19 crisis in China as well. For instance, NGOs built an online platform to disclose information about coronavirus crisis management promptly, facilitating information transparency and social trust. However, NGOs that received social donations failed to ensure financial transparency, leading to public questions. As such, constructing public trust in NGOs will boost their credibility in the public.

To investigate public distrust and accountability during COVID-19 crisis management in China, data on social media platforms, such as Sina Weibo, Zhihu and WeChat communities, can be collected to analyse the characteristics and content of public distrust. Due to isolation at home during the COVID-19 pandemic, social media became the mainstream tool for people to interact with others. Unlike traditional online communication tools, mobile social media have the characteristics of decentralised communication structure, real-time broadcasting and public participation. It is fundamentally different from the traditional media environment, and the hotspots on mobile social media switch fast and suddenly. If governments and social organisations understand social media debates and responses, they can take measures to alleviate public distrust effectively (Hoffman et al., 
2019; Zhou et al., 2019). To analyse these online data, big data analytic software, such as Prism 8 or Gephi 8.2, could be utilised to chart the changes in public concern on social media during the COVID-19 pandemic in China and to generate visualisation of the contents of public distrust. Subsequently, a qualitative study could be conducted to interview diverse stakeholders, such as clinicians, local officials, citizens, journalists and CDC experts in China, to understand different perspectives regarding management of the COVID-19 crisis and public trust in China.

\subsection{A need for participatory governance systems at transnational levels}

The increasing risks in the global food and vaccine supply chains not only require national authorities to reflect on their governance structures but also require transnational cooperation to ensure food and vaccine safety and to effectively deal with global public health crises. While national authorities need to address these issues, private enterprises and social organisations also need to set up criteria regarding food and vaccine safety governance, monitor risks, share information, trace unsafe products, manage crises and train personnel (Zach et al., 2012; Havinga and Berbruggen, 2017). For whatever may go wrong in one nation, food and vaccine safety is a global issue.

\section{References}

Felt, U., Fouché, R., Miller, C.A. and Smith-Doerr, L. eds., 2017. The handbook of science and technology studies. Mit Press.

Fricker, M., 2007. Epistemic Injustice: Power and the Ethics of Knowing. Oxford University Press.

Havinga, T. and Verbruggen, P., 2017. The Global Food Safety Initiative and state actors: Paving the way for hybrid food safety governance. In Hybridization of Food Governance. Edward Elgar Publishing.

Heimer, M. and Thøgersen, S., eds., 2006. Doing Fieldwork in China. University of Hawaii Press.

Hoffman, B.L., Felter, E.M., Chu, K.H., Shensa, A., Hermann, C., Wolynn, T., Williams, D. and Primack, B.A., 2019. It's not all about autism: The emerging landscape of anti-vaccination sentiment on Facebook. Vaccine, 37(16), pp. 2216-2223.

$\mathrm{Hu}$, Y., 2018. Logic and dilemma of surplus regulatory power_—Based on the analysis of food safety regulatory system. Jiang Haixue, 3(2), pp. 129-137.

Jeffreys, E. and Sigley, G., 2009. Governmentality, governance and China. In China's Governmentalities. Routledge, pp. 13-35.

Miles, S., 2017. Stakeholder theory classification, definitions and essential contestability. Stakeholder Management; Emerald Publishing Limited: Bingley, UK, pp.21-47.

Paphitis, S.A., 2018. The possibility of addressing epistemic injustice through engaged research practice: Reflections on a menstruation-related critical health education project in South Africa. Critical Public Health, 28(3), pp. 363-372.

Yan, H., 2010. Reform of my country's food safety regulatory system: An analysis based on the theory of holistic government. Academic Research, 4(5), pp. 51-60, 168.

Yang, R., 2020. Managing the Covid-19 pandemic in China: Managing trust and accountability. Maastricht $U M C+$. https://www.caphri.nl/managing-covid-19-pandemic-china-managing-trust-and-accountability

Zach, L., Doyle, M.E., Bier, V. and Czuprynski, C., 2012. Systems and governance in food import safety: A US perspective. Food control, 27(1), pp. 153-162. 
Zhiren, S.X.Z., 2008. A glimpse at Chinese study of the humanities and social sciences from CSSCI. Jiangsu Social Sciences, 2 (2), pp.12-15.

Zhou, M., Qu, S., Zhao, L., Kong, N., Campy, K.S. and Wang, S., 2019. Trust collapse caused by the Changsheng vaccine crisis in China. Vaccine, 37(26), pp. 3419-3425. 


\section{Summary}

In chapter 1, I present the background of food and drug safety governance in China and raise research questions about how public accountability of food and vaccine safety is debated by diverse stakeholders in China. To study this research question, I took the melamine milk scandal in 2008 and Changchun Changsheng vaccine scandal in 2018 as examples and conducted scoping reviews and qualitative studies to understand food and vaccine safety governance within the theoretical lenses of public accountability, science and technology studies and public understanding of science, which originated from the Western democratic context. In addition, in Chapter 1, I delineate the challenges, strategies and dilemmas when doing fieldwork in China.

In Chapter 2, I conduct a scoping review of Chinese academic databases in the format of document analysis. The analysis shows how Chinese scholars study and discuss public accountability of food safety in terms of risk assessment, transparency and supervision and accountability. The analysis of these scholarly debates shows how different assemblages of politics and science are proposed along the way of food safety governance. Several scholars have argued in favour of strengthening centralised power, emphasising that a unified supervisory model and a top-down approach to the governance of food safety will help alleviate challenges in establishing boundaries between responsibilities, information transparency and governments dodging blame. Others have proposed de-centralisation and argue that decentralised power was and will be able to facilitate food safety supervision and accountability as the food chain becomes increasingly complex. They argue that decentralisation supplemented with (some degree of) stakeholder participation would help overcome deficits associated with top-down governance. These deficits include the risks that accompany absolute power, corruption, and overly close ties between experts and the state. Involving other stakeholders, they argue, would promote transparency, discussion and a negotiation between diverse ways to perceive risks, thus slowly creating the required support and participation needed to work towards consensus.

In chapter 3, I conduct a qualitative analysis of the narratives of diverse stakeholders on the food safety crisis and the governance infrastructure a decade after the melamine crisis. I interviewed mothers, government officials, the dairy industry, journalists and experts in China during January and March 2018. The chapter shows how different stakeholders conceive of public accountability of food safety very differently. This study shows that stakeholders engaged in discussing dynamics of infant formula governance have viewed the governance and accountability landscape and its changes differently. Officials stress government reform, aiming to improve the efficiency of governance 
through various means, such as the central model replacing the segmented model, strict accountability, top-down risk assessment, and segmented information disclosure facilitated by a coordination system. Academics stress the need for a decentralised forum where non-government stakeholders participate in governance and share accountability, rather than the public sphere being included nominally, a position largely shared with the young mothers we talked to. Members of the media perceive risks and benefits critically, sceptically approaching co-governance systems where and when centralised models and public participation were fused. They stress potential risks, such as the weak incentives associated with the top-down model, extremely limited capacity of public participation and the lack of authority for third parties in the decentralised market.

In chapter 4, I turn again to academia. I conduct a scoping review to exhibit how scholars study and discuss vaccine hesitancy in China following a series of vaccine incidents emerging over the last few decades. This chapter maps how Chinese scholars relate vaccine hesitancy to vaccine safety and its control system, to parent beliefs and to inappropriate medical conduct and which potential solutions they have put forward. This scoping review of studies is related to the governance of vaccine hesitancy that was published in China between 2007 and September 2019. The findings indicate that most studies on vaccine hesitancy have defined it as a problem related to vaccine incidents and vaccine safety. A smaller number of studies have defined it as a problem related to professional conduct, and a very small number have defined it as a problem related to parental beliefs or concerns. Accordingly, most studies have assigned the responsibility for vaccine hesitancy to governance system factors, such as an inadequate supervision and reduced participation and transparency. As solutions, they have proposed reformation of the supervision model, a strict top-down accountability system and participatory turns in crisis response. A handful of studies have ascribed vaccination hesitancy to less-responsive and less-experienced doctors and relatively outdated technical equipment at the grassroots level. Professional training, resource investment, and regulation of doctors have been called for as solutions. Studies that have focused on parental doubts and beliefs have pointed to the influence of the media and inadequate public education. These studies proposed public outreach and communication as solutions. A few studies have evaluated the new policies formulated to tackle this problem and have pointed to diverse factors that have hampered the effective implementation of these policies.

In chapter 5, I present an analysis of how different stakeholders consider vaccination hesitancy in China and public accountability and governance of vaccine safety. I analysed online vaccination narratives and interviews with parents, public health professionals and media professionals. In a similar way as in chapter 3 , the analysis shows very different perspectives between experts and laypeople regarding vaccination hesitancy in China. CDC experts, clinicians and two of our parent respondents considered vaccines safe for the general public despite a few flaws in some 
regional areas. They favoured the NIP, based on how it was logistically organised: signing informed consent, single shots of vaccines and the absence of antibody tests. They also justified past crisis responses as transparent and rational. The other half of the parent respondents and all the self-diagnosed victims presented different views. They considered vaccines unsafe and risky for their children. They also criticised compulsory signing of informed consent forms as a way to exempt doctors from responsibility for incidents. Contrary to the experts, these parents also preferred combined shots of vaccines and performing antibody tests on their children. They were not convinced by the responses of experts and public health bodies to vaccination incidents and called for more transparency and public engagement in crisis responses. A few independent experts and journalists mentioned the same risks in vaccine safety, vaccination organisations and crisis responses as these parents, and they considered parental mistrust in the NIP a result of a failure of science popularisation in China.

In chapter 6, I conclude that the governance of public health is steered by the state in China, and persistent public health crises in China with respect to baby food and vaccine safety have decreased public trust in the governance system of public health authorities. Different stakeholders have pointed to accountability deficits, lack of information transparency and lack of participatory governance as a source of public distrust. As solutions, they have proposed an even more stringent and centralised top-down accountability system, an information traceability system, a more symmetrical science communication mechanism between experts and the public and genuine public engagement in risk assessment practices. Compared to Western scholarship, most Chinese stakeholders in my study preferred to consider public accountability and scientific knowledge as technical instruments favouring institutional efficiency rather than as deliberative practices that serve democratic virtues. 


\section{Acknowledgements}

This dissertation is almost done. This is an end of my $\mathrm{PhD}$ journey but is also a start for new stage. 1 would to share this happiness, excitement and success with the people who accompanied me during this journey.

First and foremost, 1 wish to express my deepest gratitude to my supervisors, Klasien Horstman and Bart Penders, for their consistent support, patient guidance and generous help during this project. From the inception to its completion, they have devoted so much into my study. Klaisen, if 1 managed to master the art and science of qualitative study, the credit should go to you. During the almost four years in Masstricht university, 1 derived a good ideal of benefits from your guidance. You constantly taught me how to conduct academic research scientifically, how to reason theoretical consequences from the observable data, and how to narrate respondents' stories vividly instead of diving into theory. Under your persistent guidance, I have become more confident in conducting academic research. In addition, your kindness, straightforward and rigorous academic attitude have deeply impressed me. 1 learned so much from you about the philosophy and academia.

Bart: you are both my mentor and friend. You provided me an opportunity and the specific proposal regarding science and governance of food safety to conduct this $\mathrm{PhD}$ project. Although I was not very familiar with this field at first, now I am deeply in love with this field. During the long-term interaction with you, your conscientious academic spirit, optimistic attitude, open-minded personality and academic enthusiasm have inspired me in academic research and daily life. When I got confused and frustrated in research, you not only shared a lot of relevant literature to stimulate my thoughts, but also provided a lot of insightful ideas and suggestions to help me overcome these obstacles and set me on the right path. During the paper writing, you carefully revised my draft and proposed many constructive suggestions to help me go further. Without your assistance, 1 couldn't have finished my study so smoothly.

In addition, 1 would like to pay my special regards to these Chinese respondents who engaged in my interviews, especially officials in Food and Drug Administration, doctors and journalists in Xinyang, Wuhan and Changsha cities. Without their participation, 1 could not finish the data collection. At the beginning of project, officials and doctors working in public institutions hesitated and refused to engage in my interview, as the study interviews involved in many political sensitive topics. I even lost confidence for unable to access to potential participants. Thank these participants for their trust me. 
Meanwhile, multiple rounds of interviews and interactions have enabled me to establish good personal relationships with many participants.

My deepest gratitude also goes to those lovely colleagues around me in the Department of Health, Ethics and Society, who make my PhD life into an enriching, relaxing and surprising journey. I would like to thank you: Thomas Krafft and Eva Pilot inviting me to have a dinner at home in the first week when 1 arrived in Maastricht, Guido de Wert, a humble scholar keeping enthusiastic about academia and life, Mare Knibbe, Panjun Gao, Alena Kamenschikova, Lock-Wah-Hoon Jerome, Pereira Daoud Ana, Bongers Lisette, Ghergu Cristian, Eva Pilot, Pas, Remco van de, Sanne Raap, Rehbock Cassandra, Stapleton Greg, Angelique Heijnen, Hellen Heutz, Kramer Kyra, and the other HES-junior and HES-seniors.

1 would like to acknowledge the support of my parents and girlfriend Wenjie for their continuous and unparalleled love, help and support.

On a final rote, 1 would like to thank you the Chinese Scholarship council (CSC) and Maastricht university for supporting me to conduct this study. 


\section{Curriculum vitae}

Ronghui Yang was born on $22^{\text {nd }}$ of January 1990 in Xinyang, a beautiful city in the Henan province in China. Ronghui started his study of Social Work at Xinyang Normal University in 2008 and received his bachelor degree in Jun, 2012. After that, he continued his Master's education, majoring in Sociology at Central South University, Changsha, China. His Master's thesis was entitled 'The new urbanization policy in China: Public engagement in community governance', under supervision of Prof. Bin Li. In January 2017, Ronghui started his PhD research at Department of Health, Ethics and Society in Maastricht University under supervision of Prof. Klasien Horstman and Dr. Bart Penders. His research has focused on public accountability of food and vaccine safety in China, and the results are described in this thesis. 


\section{Scientific output}

Yang, R., Penders, B. and Horstman, K., 2020. Addressing Vaccine Hesitancy in China: A Scoping Review of Chinese Scholarship. Vaccines, 8(1): 2. doi: 10.3390/vaccines8010002.

Yang, R. 2020. "Managing the COVID-19 Pandemic in China: Managing Trust and Accountability." SocArXiv. April 12. doi: 10.31235/osf.io/az8qk.

Yang, R., Horstman, K. and Penders, B., 2020. Constructing the accountability of food safety as a public problem in China: a document analysis of Chinese scholarship, 2008-2018. Journal of Chinese Governance, pp.1-27. doi: 10.1080/23812346.2020.1796160.

Yang, R., Penders, B. and Horstman, K., 2020. Vaccine hesitancy in China: A qualitative study of expert and lay perspectives. Vaccines. (Under second review)

Yang, R., Horstman, K. and Penders, B., 2020. Stakeholder Perspectives on Infant Formula Safety Governance in China: A Decade after the Melamine Crisis. Food, Culture and Society. (Under second review)

Yang, R., 2020. Technical governance, efficiency and the emergence of differentiation: A cross-sectional study of food safety regulation in China. Chinese Sociology Journal. (Under second review)

Yang, R., Penders, B. and Horstman, K., 2020. Controlling the COVID-19: Public sentiments towards Chinese public health governance system. (In preparation) 
